\title{
U.S. Geological Survey Artificial Recharge Workshop Proceedings, April 2-4, 2002, Sacramento, California
}

George R. Aiken and Eve L. Kuniansky, editors

U.S. Geological Survey

Open-File Report 02-89 


\section{U.S. DEPARTMENT OF THE INTERIOR \\ GALE A. NORTON, Secretary}

U.S. GEOLOGICAL SURVEY

CHARLES G. GROAT, Director

The use of firm, trade, and brand names in this report is for identification purposes only and does not constitute endorsement by the U.S. Government.

For additional information, please write to:

Office of Ground Water

U.S. Geological Survey

http://water.usgs.gov/ogw/pubs.html 


\section{Contents}

Introduction $\quad 1$

Artificial Recharge Workshop Agenda 2

Oral Session Abstracts 5

A Historical Overview of Hydrologic Studies of Artificial Recharge in the U. S. Geological Survey by E.P. Weeks

The Role of Unsaturated Flow in Artificial Recharge Projects by Alan L. Flint 13

The Role of Saturated Flow in Artificial Recharge Projects by Steven P. Phillips 17

Organic Matter in Ground Water by George Aiken 21

Processes Controlling Attenuation of Dissolved Organic Matter in the Subsurface by Jerry A. Leenheer 24

Fate of Disinfection By-products in the Subsurface by Colleen Rostad 27

Impact of Organic Contaminants on the Evolution of Aquifer Geochemistry By Isabelle M. Cozzarelli 31

Long Term Fate of Organic Micro-pollutants in the Subsurface Environment, Cape Cod, Massachusetts - From

Field Surveys to Experimentation by Larry B. Barber

Geochemical Modeling of an Aquifer Storage Recovery Experiment, Charleston, South Carolina by

David L. Parkhurst and Matthew D. Petkewich

Transport and Fate of Water-Quality Indicators after 40 Years of Artificial Recharge with Treated Municipal Wastewater to the Central Ground-Water Basin in Los Angeles County by Roy A. Schroeder and Robert Anders

Mobilization of arsenic and other trace elements during aquifer storage and recovery, southwest Florida by Jonathan D. Arthur, Adel A. Dabous, and James B. Cowart

Using chemical and isotopic tracers to assess hydrogeologic processes and properties in aquifers intended for injection and recovery of imported water by John Izbicki

Feasibility of Regional-Scale Aquifer Storage and Recovery (ASR): Scientific Uncertainties by Carl R.

Goodwin

Why do Bacteria Colonize Aquifer Surfaces? Geochemical and Nutrient Controls of Bacterial Colonization of Silicate Surfaces by Jennifer Roberts Rogers

Fate And Transport of Bacterial, Viral, and Protozoan Pathogens During ASR Operations- What Microorganisms Do We Need To Worry About And Why? By David Metge

Detection of Microbial Indicators and Human Microbial Pathogens in Artificial Recharge Studies by Dale W. Griffin

Microbial Strategies for Degradation of Organic Contaminants in Karst by Tom D. Byl, Gregg E. Hileman, Shannon D. Williams, David W. Metge, and Ron W. Harvey

Microbial Redox Cycling of Arsenic Oxyanions in Anoxic Environments by Ronald S. Oremland 
Planning for the Future of New York City's Water Supply System Using Artificial Recharge in the Coastal Plain Aquifers: A Cooperative Program between the USGS and the New York City Department of

Environmental Protection by William A. Yulinsky, Paul Misut, and Donald K. Cohen

Poster Session Abstracts

Correlations between Various Water-Quality Indicators of Recharged Recycled Water in Production Wells in Los Angeles County, California, by Robert Anders and Roy A. Schroeder

Attenuation Rates for PRD-1 and MS2 During Recharge with Artificial Recharge with Recycled Water at a Research Basin in Los Angeles County, by Robert Anders, William A. Yanko, Roy A. Schroeder, and James L. Jackson

Using Environmental Tracers to Determine Long-Term Effects of Recharging Recycled Water in the Central Ground-Water Basin, Los Angeles County, California, by Robert Anders and Roy A. Schroeder

Heat as a tracer for examining enhanced recharge processes along the Russian River, California, by James Constanz

Nitrate contamination and incorporation of excess air associated with artificial recharge in a desert basin, Yucca Valley, California, by Jill N. Densmore and J.K. Böhlke

Processes Affecting the Trihalomethane Concentrations Associated with the Injection, Storage, and Recovery Tests at Lancaster, Antelope Valley, California, by Miranda S. Fram, Roger Fujii, Brian A. Bergamaschi, Kelly D. Goodwin, and Jordan F. Clark

Permeability Reduction Caused by Trapped Gas: Field-Scale Observations and Quantification With a Dissolved-Gas Tracer During a Ponded Infiltration Experiment, by Victor M. Heilweil and

Artificial Recharge through a Thick, Heterogeneous Unsaturated Zone near an Intermittent Stream in the Western Part of the Mojave Desert, California, by John A. Izbicki and Christina L. Stamos

Simulation of the Effects of Reclaimed-Water Application in West Orange and Southeast Lake Counties, Florida, by Andrew M. O’Reilly

Flow system analysis using a surface-applied tracer at the Idaho National Engineering and Environmental Laboratory, Idaho, by Kim S. Perkins, John R. Nimmo, Peter A. Rose, Joseph P. Rousseau, Brennon R. Orr, Brian V. Twining, and Steve R. Anderson

Aquifer Storage and Recovery in the Santee Limestone/Black Mingo Aquifer, Charleston, South Carolina, 1993-2001, by Matthew D. Petkewich, Kevin J. Conlon, June E. Mirecki, and Bruce G. Campbell

Review and Hydrogeology of Aquifer Storage and Recovery Sites in Southern Florida, by Ronald S.

Reese

Technical Considerations for a Large Network of ASR wells in the Comprehensive Everglades Restoration Program by Robert A. Renken, Michael W. Fies and Shawn B. Komlos

Effects of Artificial Recharge on Water Quality in the Equus Beds Aquifer, South-Central Kansas, by Andrew

C. Ziegler and Heather C. Ross 


\section{INTRODUCTION}

The Office of Ground Water sponsored an interdisciplinary National Artificial Recharge Workshop April 2-4, 2002 in Sacramento, California. Artificial Recharge includes: recharge enhancement structures or infiltration enhancement; aquifer storage and recovery; or any injection of surface water into aquifers. The broad purposes of the workshop were to assess what we know about the major issues and identify promising future scientific directions for the U.S. Geological Survey (USGS) in artificial recharge. The agenda for the meeting included the following sessions with invited speakers and panelests:

- Artificial Recharge Systems - Current Use, Challenges and Limitations

- Flow-System Analysis, Geologic Controls, Hydraulics, and Optimization

- Organic Geochemical Interactions

- Inorganic Geochemical Interactions

- Microbiology

- Artificial Recharge Systems - Information Needs to Expand Opportunities

A poster session was held in order to provide a less formal environment for discussions with USGS scientists involved in artificial recharge related investigations.

The workshop was an excellent opportunity for scientists and managers within the USGS who are interested in artificial recharge to exchange information, hear from some of the prominent people working in the field, present their findings at the poster session, and help to develop the future directions of the USGS.

This proceedings volume is a compilation of papers from invited speakers and abstracts from participants of the poster session. The proceedings volume serves as a useful reference for attendees of the workshop and for those unable to attend.

The following people served on the organizing committee for the workshop: George Aiken, Bill Alley, Ronnie Best, Devin Galloway, Carl Goodwin, Ron Harvey, Rick Healy, Brian Katz, Ken Kipp, Eve Kuniansky, Eric Reichard, Tom Reilly, and Bruce Wardlaw.

The abstracts of USGS authors were reviewed and approved for publication by the U.S. Geological Survey. Articles submitted by University researchers and other Agencies did not go through the USGS review process, and therefore may not adhere to USGS editorial requirements or stratigraphic nomenclature. The use of trade names in any article does not constitute endorsement by the U.S. Geological Survey. 


\section{ARTIFICIAL RECHARGE WORKSHOP AGENDA}

Tuesday, April 2, 2002

7:00 AM Registration

8:00 AM Artificial Recharge Systems - Current Use, Challenges and Limitations(Chair - William Alley)

Workshop introductory remarks (15 minutes) - Michael Shulters (District Chief, Sacramento, CA)

Goals of the workshop (15 minutes) - William Alley (Chief, Office of Ground Water, Reston, VA)

Keynote Presentation (30 minutes) - Recharge and Water Management in California - Jonas Minton (Deputy Director, California Department of Water Resources, Sacramento, CA)

Keynote Presentation (30 minutes) - Ronald Gastelum (President and CEO of Metropolitan Water District of Southern California, Los Angeles, CA)

9:30 AM Break

10:00 AM Artificial Recharge Systems - Current Use, Challenges and Limitations (continued)

Keynote Presentation (30 minutes) - Current use, challenges, and limitations of alternative recharge techniques: Indirect water reuse, and aquifer storage and recovery of stormwater Fred Rapach (Policy/Program Coordinator, Palm Beach County Water Utilities Department, Palm Beach County, FL)

10:30 AM Flow-system analysis, geologic controls, hydraulics, and optimization (Chair - Rick Healy)

A historical overview of the role of the USGS in flow-system analysis of artificial recharge projects (30 minutes) - Ed Weeks (USGS, Denver, CO)

The role of unsaturated flow in artificial recharge projects (30 minutes) - Alan Flint (USGS, Sacramento, CA)

11:30 AM Lunch

1:00 PM Flow-system analysis, geologic controls, hydraulics, and optimization (continued)

The role of saturated flow in artificial recharge projects (30 minutes) - Steven Phillips (USGS, Sacramento, CA)

Modeling tools available for saturated and unsaturated flow-system analysis of artificial recharge projects (30 minutes)

Cliff Voss (USGS, Reston, VA)

2:00 PM Organic geochemical interactions (Chair - Brian Bergamaschi)

Introduction: Organic matter in ground water (30 minutes) - George Aiken (USGS, Boulder, $\mathrm{CO})$

Processes controlling attenuation of dissolved organic matter in the subsurface (30 minutes) Jerry Leenheer (USGS, Denver, CO) 
3:00 PM Break

3:20 PM Organic geochemical interactions (continued)

The fate of disinfectant byproducts in the subsurface (30 minutes) - Colleen Rostad (USGS, Denver, CO)

The role of organic matter in the evolution of ground-water geochemistry (30 minutes) Isabelle Cozzarelli (USGS, Reston, VA)

Long-term fate of micropollutants in the subsurface (30 minutes) - Larry Barber (USGS, Denver, $\mathrm{CO}$ )

4:50 PM Panel Discussion on the 'Flow System Analysis Session' and the 'Organic Geochemical Interactions Session' (40 min) - Eric Reichard, Ed Weeks, and others

5:30 PM End for the day

Wednesday April 3, 2002

8:00 AM Inorganic Geochemical interactions (Chair - Carl Goodwin)

Geochemical approaches for artificial recharge projects (30 minutes) - David Parkhurst (USGS, Lakewood, CO)

Fate and transport of water-quality indicators in the central ground-water basin of Los Angeles County during 40 years of wastewater recharge (30 minutes) - Roy Schroeder (USGS, San Diego, CA)

Mobilization of arsenic and other trace elements during aquifer storage and recovery(30 minutes) - Jon Arthur (Florida Geological Survey, Tallahassee, FL)

9:30 AM Break

9:45 AM Inorganic Geochemical interactions (continued)

Using chemical and isotopic tracers to assess hydraulic connections between shallow and deep aquifers in areas intended for aquifer storage and recovery (30 minutes) - John Izbicki (USGS, San Diego, CA)

Scientific uncertainties regarding regional-scale feasibility of aquifer storage and recovery (ASR) (30 minutes) - Carl R. Goodwin (USGS, Tallahassee, FL)

Panel Discussion (40 min) - David Parkhurst, Jon Arthur, Carl Goodwin, and Brian Katz

11:25 AM Lunch

1:00 PM Microbiology (Chair - Tom Byl)

Clogging -- "Why do bacteria colonize aquifer surfaces? Geochemical and nutrient controls of bacterial colonization of grain or rock surfaces" (30 minutes) - Jennifer Roberts Rogers (University of Kansas, Lawrence, KS)

Fate $\&$ transport -- "Fate $\&$ transport of bacterial, viruses, and protozoan pathogens during ASR operations - What are the microorganisms that we need to worry about and why?" (30 minutes) - David Metge (USGS, Boulder, CO) 
Pathogen detection -- "Who's who at the zoo - Identifying and counting the microbial 'bad guys' of ASR" (30 minutes) - Dale Griffin (USGS, St. Petersburg, FL)

2:30 PM Break

2:45 PM Microbiology (continued)

Microbial degradation of organics -- "Microbial strategies for degradation of organic contaminants in karst - How do they do it and what would change as a result of ASR operations?" (30 minutes) - Tom Byl (USGS, Nashville, TN)

Microbial transformations of metals and metalloids -- "Bacteria that mettle with metals: How do they affect mobility and toxicity of metals and metalloids and how might this be affected by ASR operations?" (30 minutes) - Ron Oremland (USGS, Menlo Park, CA)

Panel Discussion 4 to 5 members (40 min)

4:25 PM POSTER SESSION (Chair - Eve Kuniansky)

6:30 PM End for the day

Thursday, April 4, 2002

8:30 AM Artificial recharge systems - Information needs to expand opportunities (Chair - William Alley)

Keynote Presentation (30 minutes) - Carl Hauge (Chief Hydrogeologist, California Department of Water Resources, Sacramento, CA)

Keynote Presentation (30 minutes) - TBD

Keynote Presentation (30 minutes) - Planning for the Future of New York City's Water Supply System Using Artificial Recharge in the Coastal Plain Aquifers - Donald K. Cohen (Senior Hydrogeologist, Malcolm Pirnie, Inc., Jackson Heights, NY)

10:00 AM Break

10:30 AM Artificial recharge systems - Information needs to expand opportunities (continued)

Synthesis of workshop - Priority research needs \{5-10 minutes synthesis resulting from each major session and discussion $\}$ (60 minutes)

- Flow-system analysis, geologic controls, hydraulics, and optimization - Thomas Reilly

- Organic geochemical interactions - George Aiken

- Inorganic geochemical interactions - Brian Katz

- Microbiology - Ron Harvey

- Artificial recharge systems - Ronnie Best

- Poster session - Eve Kuniansky

- Discussion

11:30 AM Closure - William Alley 


\title{
ORAL SESSION ABSTRACTS
}

\section{A Historical Overview of Hydrologic Studies of Artificial Recharge in the U. S. Geological Survey}

\author{
E.P.Weeks (epweeks@usgs.gov) \\ U.S. Geological Survey, P.O. Box 25046, MS 413, Denver Federal Center, Lakewood, Colorado 80225
}

\begin{abstract}
An overview of artificial recharge studies requires a precise definition of the topic to be covered. Todd (1959) defines artificial recharge, for his bibliography, as "the practice of increasing by artificial means the amount of water that enters a ground-water reservoir." For this review, a narrower definition is invoked that includes direct recharge of potable water through spreading basins, pits, and injection or drainage wells, but excludes induced infiltration from wells, galleries, and collectors placed near streams. Deep well waste disposal and irrigation with sewage effluent as a recharge mechanism are not included. Literature reviews, except those used here, and papers that only mention artificial recharge as a solution to water-supply problems are also omitted. Sources of information for this review include Todd's (1959) bibliography of artificial recharge through 1954, Signor et al.'s (1970) bibliography for 1955-67, and the web-based Water Resources Abstracts for the period after 1967. Studies that have not resulted in citation by those sources, such as those summarized in administrative reports, are thus not included.

Early U.S. Geological Survey (USGS) interest in artificial recharge focused on the use of drainage wells to reclaim wetlands for agriculture, with reference to sites in Michigan, Georgia, Arkansas, and Minnesota (Horton, 1905; Crider, 1906; Fuller, 1911; Hall et al., 1911). Many of the drainage wells described in these studies failed due to clogging by sediment suspended in the drainage water. Drainage wells that recharged the Floridan aquifer, consisting of highly porous and permeable limestone were more successful, and Stringfield $(1933,1936)$ describes an extensive network of drainage wells in Orlando, Florida that recharged storm runoff and sewage to the Floridan aquifer. The hydrologic and water quality impacts of these drainage wells are described by Unklesbay and Cooper (1946). Drainage wells tapping highly fractured basalt aquifers were also successful. Stearns et al. (1938) and Stearns et al. (1939) describe the use of a pit and wells to drain surface water into basalts in the Snake River Plain of Idaho.
\end{abstract}

Significant interest developed during the 1930s, particularly in California and New York, in the use of artificial recharge to conserve or enhance ground-water storage. In California, artificial recharge of alluvial aquifers with storm runoff by use of spreading basins began about the turn of the century, and was a widespread practice by the 1930s. However, I found no record of USGS involvement in related studies during that period. In New York, water levels in a significant area of western Long Island had been drawn down below sea level by the early 1930's due to ground-water pumpage, much of it for air conditioning. The cool ground water was used to cool air in heat exchangers, and then often discharged to waste. Legislation passed in 1933 required that ground water pumped for air conditioning be recharged, either by well injection or through spreading basins. Hydrologic and temperature effects of this recharge were analyzed by Leggette and Brashears (1938), and by Brashears (1941, 1946). Artificial recharge to conserve water was also practiced in several municipalities in northern New Jersey, as described by Barksdale and DeBuchananne (1946).

After World War II, significant interest in artificial recharge developed within the USGS. Cederstrom (1947) conducted an experiment to store fresh water by well injection into a brackish aquifer in Virginia. Rorabaugh (1949) describes the use of well injection to replenish an alluvial aquifer near Louisville, Kentucky. Sniegocki (1953) proposed a study of injection-well recharge in the Grand Prairie region of Arkansas, a proposal that led to an extensive project to identify problems related to injection-well recharge, as described by Sniegocki et al. (1965) and in papers cited therein. Moulder and Frazor (1957) conducted interaquifer well injection experiments in the City of Amarillo, Texas well field. Cronin (1964) describes results of well injection of water that collects in the numerous playa lakes that dot the Southern High Plains in Texas. Hart (1958) inventoried artificial recharge practices at nine sites in Washington and Oregon, mostly by injection by wells tapping the Columbia River basalt aquifer, but also by spreading basins to recharge alluvium. Price (1961) evaluated the hydrologic effects of artificial recharge of 
Columbia River basalts by well injection conducted by personnel of the City of Walla Walla, Washington, and Foxworthy (1969) conducted a similar study for the City of Salem, Oregon. Brown (1963) describes effects of reinjection of ground water pumped for air conditioning on the hydrology of the Columbia River basalts in the City of Portland, Oregon.

In the late 1960s, separate considerations led to greatly increased interest in artificial recharge in the States of California, Texas, and New York, all of which heavily involved the USGS in artificial recharge studies. The California Water Plan was approved to import several million acre feet of water from northern to southern California each year, with the plan that much of the imported water be stored in the subsurface through artificial recharge. USGS personnel evaluated various sites for their potential for artificial recharge, and 16 papers describing these studies were prepared, including, as examples, Bloyd (1971), Schaefer and Warner (1975) and Hamlin (1987). These studies typically involved test drilling, and in some cases recharge experiments. A few later studies evaluated effects of ensuing artificial recharge operations (Muir and Coplen, 1981; Reichard and Meadows, 1991; Woolfenden and Kadhim, 1997). Interest in artificial recharge continues in California, as evidenced by the work of Steve Phillips and Alan Flint being discussed at this meeting.

A proposal to import water from the Mississippi River to the Southern High Plains of Texas, predicated on the presumed future availability of very inexpensive nuclear-reactor generated electrical power, resulted in political interest in artificial recharge in the Southern High Plains of Texas and New Mexico. As a result, a line item for artificial recharge studies was inserted in the USGS budget in 1967, renewed annually until about 1980. The High Plains Artificial Recharge Project, housed in Lubbock, Texas from 1967 to 1979, was implemented through this budget authority. During the project, the water importation scheme was recognized as being infeasible, and project emphasis changed to consider recharge of sediment-laden playa lake water. Several artificial-recharge experiments were conducted, results of which are presented by Brown et al. (1978) and Brown and Keys (1985). In addition to recharge in the Southern High Plains, recharge of the Hueco Bolson, the water supply for the City of El Paso, was investigated by Garza et al. (1980) and the results of a pilot artificial recharge project and ensuing recharge operations are discussed by White and Sladek (1990). Artificial recharge of the Evangeline aquifer in the Houston area as a means to alleviate subsidence is discussed by Garza (1977).

In New York, plans to convert many areas developed with wells and septic systems to municipal water supply and sewage treatment resulted in a strong interest in artificial recharge of tertiary treated waste water. Two substantial experimental recharge facilities were constructed, and USGS personnel were prominently involved in experiments at these sites. The Bay Park facility included a deep injection well that supported several experiments. Results of these experiments are described in Professional Paper 751A-F, as cited by Vecchioli et al. (1980). Other experiments were conducted at the Meadowbrook Artificial-Recharge Project Site in East Meadow, Nassau County, which includes 5 injection wells and 11 spreading basins. Results of experiments at the site are summarized by Schneider et al. (1987), and in papers cited therein.

Artificial recharge of storm runoff by use of spreading basins has been practiced on Long Island since the 1930s. Aronson and Seaburn (1974) evaluated the performance of the 2,124 spreading basins in existence on Long Island in 1969. Seaburn (1970) and Prill and Aaronson (1973) conducted detailed studies of the operations of three of these basins. Aronson et al. (1979) conducted a study to determine whether existing spreading basins for storm water recharge could serve the dual purpose of recharging treated sewage effluent. Prill et al. (1979) also constructed a spreading basin at the site of a water treatment plant in central Long Island for additional recharge experiments. Interest in artificial recharge in the New York City area continues, as indicated in Paul Misut's poster at this workshop.

In Florida, interest continued on the hydrologic (Kimrey and Fayard, 1984) and water-chemistry impacts (Schiner and German, 1983) of drainage wells in the Orlando area. Bradner (1996) has evaluated the hydrologic effects of closure of 23 out of 400 of these drainage wells. Interest has developed in the use of connector wells to recharge the deeper Floridan aquifer from the surficial alluvial aquifer. Hutchinson and Wilson (1974) evaluated effects of a single connector well, and Knochenmus (1975) of a connector well field. Watkins (1977) and Bush (1979) experimentally evaluated the performance of connector wells. Recharge of the Floridan aquifer with surface water also received study. Meyer (1974) considered the feasibility of using canal water to supplement the groundwater supply to a Navy well field. Tibbals and Frazee (1976) experimentally evaluated storage of fresh surface water in a brackish limestone aquifer, and Sinclair (1977) experimentally evaluated several mechanisms for recharging the 
Floridan aquifer. Hickey (1979) and Hickey and Barr (1979) evaluated surface water well-injection experiments at two sites. Sumner (1996) investigated the recharge of the surficial aquifer with tertiary treated effluent using spreading basins in Orlando. Interest in artificial recharge in Florida continues with interest in use of aquifer storage and recovery as an aid to recovery of the Everglades, described at this workshop in Bob Renken's poster.

Increased development of ground water for irrigation throughout the High Plains led to USGS involvement in artificial recharge studies in the states of Kansas, Nebraska, Colorado, South Dakota, and North Dakota. Spreading-basin experiments were conducted by Gillespie and Slagle (1972), Gillespie et al. (1977) and Prill (1977) in Kansas; by Taylor (1975) and Emmons (1977) in Colorado; by Lichtler et al. (1980) in Nebraska; and by Sumner et al. (1991) in North Dakota. Lichtler et al. (1980) also conducted well recharge experiments. However, despite this intensive activity, the USGS has had only minimal involvement in the recently completed High Plains GroundWater Demonstration Program, involving artificial-recharge demonstration projects in each High Plains state, conducted under the leadership of the U.S. Bureau of Reclamation (Carter, 1996). Other USGS studies associated with artificial recharge in the High Plains states include feasibility and modeling studies of artificial recharge of alluvial aquifers in the South Platte River basin, Colorado (Burns, 1980; 1984), and of alluvial aquifers in South Dakota (Koch, 1984; Emmons, 1987). Interest in artificial recharge in the High Plains continues, as indicated by the study of artificial recharge of the Equus beds in Kansas described at this workshop in Andy Zeigler's poster.

Artificial recharge of basalt aquifers in Washington, Oregon, and Idaho has received additional USGS attention since the 1960s. Norvitch et al. (1969) studied the feasibility of artificial recharge of the Snake River Plain basalt aquifer in Idaho, while Garrett and Longquist (1970) and Karlinger and Hansen (1983) have explored the possibility of artificial recharge of the Columbia River basalt aquifer.

Experiments involving storage of fresh water in brackish aquifers in coastal environments were conducted by Brown and Silvey (1977), enhancing the earlier work of Cederstrom (1947). Brown and Silvey report clogging due to the dispersion of sodic clays in the aquifer that can be stabilized by chemical pretreatment. Similar wellinjection experiments are now being conducted in South Carolina, as will be described at this workshop by Dave Parkhurst and in a poster by Matt Petkewich.

Although USGS artificial recharge studies have been concentrated in a few states, they also have been conducted to a lesser extent throughout the country. Spreading-basin experiments were conducted in the Ship Creek alluvial fan near Anchorage, Alaska (Anderson, 1977), and hydrologic effects of the test were analyzed using a numerical model by Meyer and Patrick (1980). Water chemistry studies have been conducted at the site of a proposed spreading-basin artificial recharge project along Rillito Creek in Tucson, Arizona (Tadayon, 1995). An experiment involving well injection of surface water into fractured limestone in West St. Paul, Minnesota was performed and analyzed by Reeder et al. (1976), and an experiment involving well injection into alluvium in Tucson, Arizona was performed and analyzed by Graham (1989). Augmented streambed recharge to alluvium in the Vicee Canyon near Carson City, Nevada was evaluated by Mauer and Fischer (1988). May (1985) explored the feasibility of injection-well recharge the 800-foot sand of the Kirkwood Formation in Atlantic City, New Jersey, using surface water from a local public supply. Hydrologic effects of long-term injection of surface water into the Kirkwood-Cohansey aquifer in Cape May County, New Jersy have been investigated by Lacombe (1996). Evaluations of the potential for artificial recharge were made for limestones in Puerto Rico by Heisel and Gonzales (1979), and for alluvium of the Carson Valley, Nevada by Mauer and Peltz (1994).

In conclusion, the USGS has played an active role in a variety of artificial recharge studies during all of the last century, with a peak in activities during the 1970s. Based on the number of current studies of artificial recharge to be described at this workshop, USGS investigations of artificial recharge, also known as aquifer storage and recovery, are continuing in good health in this century.

\section{Historical references for artificial recharge studies in the U.S. Geological Survey}

Anderson, G.S., 1977, Artificial recharge experiments on the Ship Creek alluvial fan, Anchorage, Alaska: U.S. Geological Survey Water-Resources Investigations Report 77-38, 39 p.

Aronson, D.A., and Seaburn, G.E., 1974, Appraisal of operating efficiency of recharge basins on Long Island, New 
York, in 1969: U.S. Geological Survey Water-Supply Paper 2001-D, 22 p.

Aronson, D.A., Reilly, T.E., and Harbaugh, A.W., 1979, Use of storm-water basins for artificial recharge with reclaimed water, Nassau County, Long Island, New York--A hydraulic feasibility study: Long Island Water Resources Bulletin 11, 57 p.

Bloyd, R.M., 1971, Underground storage of imported water in the San Gorgonio Pass area, southern California: U.S. Geological Survey Water-Supply Paper 1999-D, 37 p.

Bradner, L.A., 1996, Estimation of recharge through selected drainage wells and potential effects from well closure, Orange County, Florida: U.S. Geological Survey Open-File Report 96-316, 30 p.

Brashears, M.L., 1941, Ground-water temperature on Long Island, New York, as affected by recharge of warm water: Econ. Geology, v. 36, no. 8, p. 811-828.

,1946, Artificial recharge of ground water on Long Island, New York: Econ. Geology, v. 41, no. 5, p. 503- 516.

Brown, R.F., Signor, D.C., and Wood, W.W., 1978, Artificial ground-water recharge as a water-management technique on the Southern High Plains of Texas and New Mexico: Texas Department of Water Resources Report 220, 32 p.

Brown, R.F., and Keys, W.S., 1985, Effects of artificial recharge on an alluvial aquifer, Ogallala Formation, Texas: U.S. Geological Survey Water-Supply Paper 2251, 56 p.

Brown, S. G., 1963, Problems of utilizing ground water in the west-side business district of Portland, Oregon: U.S. Geological Survey Water-Supply Paper 1619-O, 42 p.

Burns, A.W., 1980, Hydrologic analysis of the proposed Badger-Beaver Creeks Artificial Recharge Project, Morgan County, Colorado: U.S. Geological Survey Water-Resources Investigations Report 80-46, 90 p.

Burns, A.W., 1984, Simulated effects of an artificial-recharge experiment near Proctor, Logan County, Colorado: U.S. Geological Survey Water-Resources Investigations Report 84-4010, 17 p.

Bush, P.W., 1979, Connector well experiment to recharge the Floridan Aquifer, East Orange County, Florida: U. S. Geological Survey Water-Resources Investigations Report 78-73, 40 p.

Carter, J.M., 1996, Hydrologic data for 1994-96 for the Huron Project of the High Plains Ground-Water Demonstration Program: U. S. Geological Survey Open-File Report 96-555, 131 p.

Cederstrom, D.J., 1947, Artificial recharge of a brackish water well: Virginia Chamber Commerce, v. 14, no. 12, p. 31, 71-73.

Crider, A.F., 1906, Drainage of wet lands in Arkansas by wells: U.S. Geological Survey Water-Supply Paper 160, p. 54-58.

Cronin, J.G., 1964, A summary of the occurrence and development of ground water in the Southern High Plains of Texas with a section on artificial recharge studies by B.N. Meyers: U.S. Geological Survey Water-Supply Paper 1693, 88 p.

Emmons, P.J., 1977, Artificial-recharge tests in upper Black Squirrel Creek Basin, Jimmy Camp Valley, and Fountain Valley, El Paso County, Colorado: U.S. Geological Survey Water-Resources Investigations Report 77-11, 49 p.

1987, Preliminary assessment of potential well yields and the potential for artificial recharge of the Elm and Middle James Aquifers in the Aberdeen Area, South Dakota: U.S. Geological Survey Water Resources 
Investigation Report 87-4017, 33p.

Foxworthy, B.L., 1970, Hydrologic conditions and artificial recharge through a well in the Salem Heights area of Salem, Oregon: U.S. Geological Survey Water-Supply Paper 1594-F, 56 p.

Fuller, M.L., 1911, Drainage by wells: U.S. Geological Survey Water-Supply Paper 258, p. 6-22.

Garrett, A.A., and Londquist, C.J., 1972, Feasibility of artificially recharging basalt aquifers in eastern Washington: U.S. Geological Survey Open-File Report, 42 p.

Garza, Serge, 1977, Artificial recharge for subsidence abatement at the NASA-Johnson Space Center, Phase I: U. S. Geological Survey Open-File Report 77-219, 82 p.

Garza, S., Weeks, E.P., and White, D.E., 1980, Appraisal of potential for injection-well recharge of the Hueco Bolson with treated sewage effluent--Preliminary study of the northeast El Paso area, Texas: U. S. Geological Survey Open-File Report 80-1106, 38 p.

Gillespie, J.B., and Slagle, S.E., 1972, Natural and artificial ground-water recharge, Wet Walnut Creek, central Kansas: Kansas Water Resources Board Bulletin no. 17, 94 p.

Gillespie, J.B., Hargadine, G.D., and Stough, M.J., 1977, Artificial-recharge experiments near Lakin, western Kansas: Kansas Water Resources Board Bulletin no. 20,91 p.

Graham, D.D., 1989, Methodology, results, and significance of an unsaturated-zone tracer test at an artificialrecharge facility, Tucson, Arizona: U.S. Geological Survey Water-Resources Investigations Report 894097, 28p.

Hall, C.W., Meinzer, O.E., and Fuller, M.L., 1911, Geology and underground waters of Minnesota: U.S. Geological Survey Water-Supply Paper 256, 406 p.

Hamlin, S.N., 1987, Evaluation of the potential for artificial ground-water recharge in eastern San Joaquin County, California--Phase 3: U. S. Geological Survey Water-Resources Investigations Report 87-4164, 17 p.

Hart, D.H., 1958, Artificial recharge to ground water in Oregon and Washington: U.S. Geological Survey open-file report, $55 \mathrm{p}$.

Heisel, J.E., and Gonzales, J.R., 1979, Water budget and hydraulic aspects of artificial recharge, south coast of Puerto Rico: U.S. Geological Survey Water-Resources Investigations Report 78-58, 102 p.

Hickey, J.J., 1979, Hydrogeologic data for the South Cross Bayou Subsurface-Injection Test Site, Pinellas County, Florida: U.S. Geological Survey Open-File Report 78-575, 87 p.

Hickey, J.J., and Barr, G.L., 1979, Hydrogeologic data for the Bear Creek Subsurface-Injection Test Site, St. Petersburg, Florida: U.S. Geological Survey Open-File Report 78-853, 53 p.

Horton, R.E., 1905, The drainage of ponds into drilled wells: U.S. Geological Survey Water-Supply Paper 145, p. 30- 39 .

Hutchinson, C.B., and Wilson, W.E., 1974, Evaluation of a proposed connector well, northeastern Desoto County, Florida: U. S. Geological Survey Water-Resources Investigations Report 74-5, 41 p.

Karlinger, M.R., and Hansen, A.J., 1983, Engineering economic analyses of artificial recharge in the Columbia Basin Project, Washington: Water Resources Bulletin, v. 19, no. 6, p. 967-975

Kimrey, J.O., and Fayard, L.D., 1984, Geohydrologic reconnaissance of drainage wells in Florida: U.S. Geological Survey Water-Resources Investigations Report 84-4021, 67 p. 
Knochenmus, D.D., 1975, Hydrologic concepts of artificially recharging the Floridan Aquifer in eastern Orange County, Florida--A feasibility study: Florida Bureau of Geology Report of Investigations no. 72, 36 p.

Koch, N.C., 1984, Effects of artificial recharge on the Big Sioux Aquifer in Minnehaha County, South Dakota: U.S. Geological Survey Water-Resources Investigations Report 84-4312, 8 p.

Lacombe, P.J., 1996, Artificial recharge of ground water by well injection for storage and recovery, Cape May County, New Jersey, 1958-92: U.S. Geological Survey Open-File Report 96-313, 29 p.

Leggette, R.M., and Brashears, M.L., 1938, Ground water for air conditioning on Long Island, N.Y.: Am. Geophys. Union Trans., v. 19, pt. 1, p. 412-418.

Lichtler, W.F., Stannard, D.I.,and Kouma, E., 1980, Investigation of artificial recharge of aquifers in Nebraska: U.S. Geological Survey Water-Resources Investigations Report 80-93, 112 p.

Maurer, D.K., and Fischer, J.M., 1988, Recharge to the Eagle Valley Groundwater Basin by augmented streamflow in Vicee Canyon, western Nevada: U. S. Geological Survey Water-Resources Investigations Report 88$4158,66 \mathrm{p}$.

Maurer, D.K., and Peltz, L.A., 1994, Potential for, and possible effects of, artificial recharge in Carson Valley, Douglas County, Nevada: U. S. Geological Survey Water-Resources Investigations Report: 94-4126, 87 p.

May, J.E., 1985, Feasibility of Artificial Recharge in the Coastal Plain near Atlantic City, New Jersey, with Emphasis on the 800-Foot Sand of the Kirkwood Formation: : U. S. Geological Survey Water-Resources Investigations Report 85-4063, 24 p.

Meyer, F.W., 1974, Availability of groundwater for the U.S. Navy well field near Florida City, Dade County, Florida: U. S. Geological Survey Open-File Report 74-014, 50 p.

Meyer, W., and Patrick, L, 1980, Effects of artificial-recharge experiments at Ship Creek alluvial fan on water levels at Spring Acres Subdivision, Anchorage, Alaska: U.S. Geological Survey Open-File Report 80-1284, 42 p.

Moulder, E.A., annd Frazor, D.R., 1958, Artificial recharge experiments at McDonald well Field, Amarillo, Texas: Texas Board of Water Engineers Bull. 5701, 34 p.

Muir, K.S., and Coplen, T.B., 1981, Tracing ground-water movement by using the stable isotopes of oxygen and hydrogen, upper Penitencia Creek alluvial fan, Santa Clara Valley, California: U.S. Geological Survey Water- Supply Paper 2075, 18 p.

Norvitch, R.F., Thomas, C.A., and Madison, R.J., 1969, Artificial recharge to the Snake Plain Aquifer in Idaho; An evaluation of potential and effect: Idaho Dep. Reclam. Water Information Bull. no.12, 59 p.

Price, C. E., 1961, Artificial recharge through a well tapping basalt aquifers, Walla Walla area, Washington: U.S. Geological Survey Water-Supply Paper 1594-A, 33 p.

Prill, R.C., and Aaronson, D.B., 1973, Ponding-test procedure for assessing the infiltration capacity of storm-water basins, Nassau County, New York: U.S. Geological Survey Water-Supply Paper 2049, 29 p.

Prill, R.C., Oaksford, E.T., and Potorti, J.E., 1979, A facility designed to monitor the unsaturated zone during infiltration of tertiary-treated sewage, Long Island, New York: U.S. Geological Survey Water-Resources Investigations $79-48,14 \mathrm{p}$.

Prill, R. C., 1977, Movement of moisture in the unsaturated zone in a loess-mantled area, southwestern Kansas: U.S. Geological Survey Professional Paper 1021, 21 p. 
Reichard, E.G., and Meadows, J.K., 1992, Evaluation of a ground-water flow and transport model of the Upper Coachella Valley, California: U. S. Geological Survey Water-Resources Investigations Report 91-4142, $101 \mathrm{p}$.

Reeder, H.O., Wood, W.W., Ehrlich, G.G., and Sun, R.J., 1976, Artificial recharge through a well in fissured carbonate rock, West St. Paul, Minnesota: U.S. Geological Survey Water-Supply Paper 2004, 80 p.

Rorabaugh, M.I, 1949, Progress report on the ground-water resources of the Louisville area, Kentucky, 1945-49: City of Louisville and Jefferson County, Kentucky (dupl. report), 64 p.

Schaefer, D.H., and Warner, J.W., 1975, Artificial recharge in the upper Santa Ana River area, San Bernardino County, California: U. S. Geological Survey Water-Resources Investigations Report 75-15, 27 p.

Schiner, G.R.and German, E.R., 1983, Effects of recharge from drainage wells on quality of water in the Floridan Aquifer in the Orlando Area, central Florida: U. S. Geological Survey Water-Resources Investigations Report 82- 4094, 124 p.

Schneider, B.J., Ku, H.F.H., and Oaksford, E.T., 1987, Hydrologic effects of artificial-recharge experiments with reclaimed water at East Meadow, Long Island, New York: U. S. Geological Survey Water-Resources Investigations Report 85-4323, 79 p.

Seaburn, G.E., 1970, Preliminary results of hydrologic studies at two recharge basins on Long Island, New York: U.S. Geological Survey Professional Paper 627-C, p C1-C17.

Signor, D.C., Growitz, D.J., and Kam, William, 1970, Annotated bibliography on artificial recharge of ground water: U.S. Geological Survey Water-Supply Paper 1990, 141 p.

Sinclair, W.C., 1977, Experimental study of artificial recharge alternatives in northwest Hillsborough County, Florida: U. S. Geological Survey Water-Resources Investigations Report 77-13, 52 p.

Sniegocki, R.T. 1953, Plans for the first year's work on the artificial recharge project, Grand Prairie region, Arkansas: U. S. Geological Survey Open-File Report, Little Rock, Arkansas, 16 p.

Sniegocki, R.T.,Bayley, F.H., Engler, Kyle, and Stephens, J.W., 1965, Testing procedures and results of studies of artificial recharge in the Grand Prairie region, Arkansas: U.S. Geological Survey Water-Supply Paper $1615-\mathrm{G}, 56 \mathrm{p}$.

Stearns, H.T., Crandall, L., and Stewart, W.G., 1938, Geology and ground-water resources of the Snake River Plain in southeastern Idaho: U.S. Geological Survey Water-Supply Paper 774, 268 p.

Stearns, H.T., Bryan, L.L., and Crandall, L., 1939, Geology and water resources of the Mud Lake region, Idaho, including the Island Park area: U.S. Geological Survey Water-Supply Paper 818, 125 p.

Stringfield, V.T., 1933, Ground-water investigations in Florida: Florida Geological Survey Bull. 11, 33 p. ,1936, Artesian water in the Floridan Peninsula: U.S. Geological Survey Water-Supply Paper 773-C, p. 115-195.

Sumner, D.M., Schuh, W.M., and Cline, R.L., 1991, Field experiments and simulations of infiltration-rate response to changes in hydrologic conditions for an artificial-recharge test basin near Oakes, southeastern North Dakota: U.S. Geological Survey Water-Resources Investigations Report 91-4127, 46 p.

Sumner, D. M., 1996, Hydraulic characteristics and nutrient transport and transformation beneath a rapid infiltration basin, Reedy Creek Improvement District, Orange County, Florida: U. S. Geological Survey WaterResources Investigations Report 95-4281, 51 p. 
Tadayon, S., 1995, Quality of Surface Water and Ground Water in the Proposed Artificial-Recharge Project Area, Rillito Creek Basin, Tucson, Arizona,1994: U. S. Geological Survey Water-Resources Investigations Report 95- 4270, 26 p.

Taylor, O.J., 1975, Artificial-recharge experiments in the alluvial aquifer south of Fountain, El Paso County, Colorado: Colorado Water Resources Circular no. 31, 28 p.

Tibbals, C.H., and Frazee, J.M., 1976, Ground-water hydrology of the Cocoa Well-Field area, Orange County, Florida: U. S. Geological Survey Open-File Report 75-676, 76 p.

Todd, D.K., 1959, Annotated bibliography on artificial recharge of ground water through 1954: U.S. Geological Survey Water-Supply Paper 1477, 115 p.

Unklesbay, A.G., and Cooper, H.H., 1946, Artificial recharge of artesian limestone at Orlando, Florida: Econ. Geology, v. 41, no. 4, p, 293-307.

Vecchioli, J, Ku, H.F.H., and Sulam, D.J., 1980, Hydraulic effects of recharging the Magothy Aquifer, Bay Park, New York, with tertiary treated sewage: U.S. Geological Survey Water-Supply Paper 751-F, 21 p.

Watkins, F.A., 1977, Effectiveness of pilot connector well in artificial recharge of the Floridan Aquifer, western Orange County, Florida: U. S. Geological Survey Water Resources Investigations Report 77-112, 28 p.

White, D.E., and Sladek, G.J., 1990, Summary of data from the 1981-83 pilot study and 1985-89 operations of the Hueco Bolson Recharge Project, northeast El Paso, Texas: U. S. Geological Survey Open-File Report 90$175,38 \mathrm{p}$.

Woolfenden, L.R., and Kadhim, D., 1997, Geohydrology and water chemistry in the Rialto-Colton Basin, San Bernardino County, California: U. S. Geological Survey Water-Resources Investigations Report 97-4012, 101 p. 


\title{
The Role of Unsaturated Flow in Artificial Recharge Projects
}

\author{
Alan L. Flint (aflint@usgs.gov) \\ U.S. Geological Survey, Placer Hall, 6000 J Street, Sacramento, California 95819-6129
}

\section{Introduction}

Artificial recharging an aquifer may be achieved by either surface spreading, injection in wells, or altering the natural conditions of stream channels to increase infiltration. Except for recharge using injection wells directly into an aquifer, artificially recharged water must first move through the unsaturated zone. For the most part, the unsaturated zone provides the underground storage space for recharge, although the amount of storage is dependent on the water retention characteristics and the natural recharge occurring at the site. The greater the natural recharge at a site, the greater the percent of porosity occupied by antecedent water moving through the unsaturated zone resulting in a smaller amount of available space for the artificially recharged water.

The hydrologic properties of an unsaturated zone help determine the suitability of a particular location for artificial recharge. Optimally, areas used for artificial recharge should have high permeability soils, the capacity for horizontal movement of water in the unsaturated zone and in the receiving aquifer, a lack of impeding layers, and a thick unsaturated zone. Under optimal conditions, water should reach the top of the saturated zone and spread laterally rather than building up a column of water toward the surface, which would greatly reduce recharge (Freeze and Cherry, 1979). The suitability of a site is often determined by field and laboratory measurements of soil properties, field experiments, and numerical modeling.

Several direct methods of artificial recharge commonly are used (Environmental and Water Resources Institute, 2001), including spreading basins and ditches for near-surface recharge applications, and pits and shafts for penetrating below near-surface restrictive layers. A third method, direct well injection into the unsaturated zone, is often used to penetrate below deeper restrictive layers. To highlight issues relating to the role of the unsaturated zone and unsaturated flow in recharging an aquifer, the following section discusses near-surface spreading basins being studied in the San Gorgonio Pass area in southern California.

\section{Site Analysis}

In 1991, spreading basins were used to test the feasibility of artificially recharging an aquifer in alluvial fans in Cherry Valley, which is within the San Gorgonio Pass area in southern California, (Shaikh and others, 1995). In 1997, the U.S. Geological Survey (USGS) was asked to evaluate the suitability of the unsaturated zone for artificial recharge and to develop models of the unsaturated and saturated zones of the San Gorgonio Pass area. Although well-organized guidelines are available for developing recharge spreading basins (Environmental and Water Resources Institute, 2001), spreading basins at this site were established in the 1960's prior to full analysis of subsurface hydrogeologic conditions and properties. Hydrogeologic data are essential in siting recharge spreading basins, particularly in alluvial basins, where soils are highly stratified and contain continuous and discontinuous clay layers interbedded with sands and gravels (Flanigan, and others, 1995).

As part of the USGS evaluation, several test wells were cored in the unsaturated zone and instrumented with deep tensiometers, heat-dissipation matric-potential sensors, temperature sensors, and suction lysimeters. Core samples and cuttings were analyzed in the USGS laboratory to determine particle-size distribution, water content, permeability, and lithology. An interpretation of these data suggests that there are several alternating high and low permeability layers between the surface and the water table (approximately 600 feet deep). A perched water table is present above a very low permeability layer, 250 feet below the surface. Results of inverse modeling of borehole temperatures and water-level measurements, which show a slow decline in the water levels in the perched zone, indicates that the vertical hydraulic conductivity of the layer is less than 1 foot per year. Data from other boreholes in the area suggest that this perched layer is the top of an old, laterally extensive, geologic formation. 
Surface-seismic and surface-resistivity measurements were used to develop a conceptual model of the layering and faulting in the area (fig. 1A). The existence of a shallow water table north of the Banning Fault suggests that the fault is a barrier to lateral flow. Temperature data from several boreholes in the area indicate that the coldest water in the unsaturated zone is the perched water. Temperature measurements made directly from flowing water in a nearby stream (San Gorgonio Creek, fig. 1) suggest that water in the perched zone is from local stream recharge, and not from the shallow water table north of the fault, which supports the hypothesis that the Banning Fault is a barrier to flow.

\section{Numerical Modeling}

The conceptual model of the unsaturated zone at San Gorgonio Pass was used for a numerical model of the unsaturated zone to further analyze existing data and to develop workable scenarios for artificial recharge.

TOUGH2, an integrated finite-difference numerical code (Pruess, 1991), was used to develop the three-dimensional model. This code simulates the flow of heat, air, water, and nitrate (assumed to be present in septic tank leach fields) in three dimensions under saturated or unsaturated conditions. The geometry of the site requires a threedimensional approach because of down-dip migration of recharged water through the alluvial fan deposits (north to south), as well as lateral flow of natural recharge (generally east to west) from the nearby stream. The modeling domain is approximately 1.6 miles (east to west) by 0.8 miles by 600 feet deep and contains more than 50,000 grid elements. The north and south lateral boundaries of the model are located along faults and are assumed no-flow boundaries. The east and west boundaries represent the edges of the alluvial basin where they encounter the mountain block. The bottom boundary is the water table and the upper boundary is specified flux. The surface flux is temporally and spatially variable depending on the artificial recharge scenario, and the location and amount of streamflow, septic tank return flow, and natural recharge from precipitation.

The model was initially developed using the hydrologic properties measured or estimated from the laboratory data. The model was further refined and calibrated by matching borehole temperature, matric potential data, and the occurrence of perched water. The model was successfully used to simulate the artificial recharge experiment conducted in 1991 and described by Shaikh and others (1995). The model simulated the measured temperature profiles by adding cold-water infiltration along the stream channel. Once calibrated, the model was run to steady-state conditions assuming natural recharge from precipitation and streamflow based on the results of the calibration of the saturated zone flow model. The model was then used to simulate historical and future artificial recharge conditions from 1950-2005. The model simulated septic tank return flows that have 80 milligrams per liter nitrate-nitrogen (nitrate reported as nitrogen), the 1991 artificial experiment, and a proposed artificial recharge scenario. For the proposed artificial recharge scenario, 1,000 acre-ft of recharge was applied over a 50-day period each year from 2001 through 2005 . The model simulation allowed comparison of measured and simulated data from 1991 to 2001, and predicted the response of the system to the proposed recharge scenario.

Before the application of artificial recharge in 1991, the simulated travel time from the surface to the water table was approximately 50 years for locations directly beneath the stream, increasing to more than 250 years for locations away from the stream. The simulated addition of artificial recharge from 2001-2005 decreased the unsaturated-zone travel time to less than 10 years directly beneath the spreading basins, but the amount of applied water that recharged the regional aquifer was less than 5 feet per year. The simulations suggest that little recharge will reach the regional water table under the spreading basin: further most of the artificially recharged water will remain above the perching layer at $250 \mathrm{ft}$ below land surface, and will mound against the down-gradient no-flow boundary located about 4,000 feet south of the spreading basins. Although the recharged water intercepts nitrates from septic tank leach fields as it spreads laterally and vertically through the unsaturated zone, the simulated nitratenitrogen concentration of water in the perched water layer is less than 10 milligrams per liter.

\section{Summary}

Generally, artificial recharge projects apply water in surface and near-surface spreading basins, pits, and trenches, using the unsaturated zone to transport and store water. The hydrogeology of the unsaturated zone plays a critical role in transporting and storing artificially recharged water. Evaluating this zone will determine if the area is suitable for artificial recharge, as well as the most effective methods of surface or subsurface application of water. Field and laboratory data, measured data, and field experiments were used to develop a conceptual and a numerical 
model of the unsaturated zone at San Gorgonio Pass in southern California. The results of the model simulations were used to refine the conceptual model and to test scenarios for artificial recharge. Results of the numerical model simulations of this site indicate that little recharge will reach the regional aquifer beneath the spreading basins, and that most of the water will remain above a perching layer at 250 feet below land surface, and will mound along the assumed no-flow fault boundary located about 4,000 feet south of the spreading basins. Further work on the characteristics of the fault and extension of the modeling domain further down gradient of the fault are required to provide more conclusive results for the characterization of the site for the application of artificial recharge.

\section{References Cited}

Environmental and Water Resources Institute, 2001, Standard guidelines for artificial recharge of ground water: Reston, Va, American Society of Civil Engineers, 106 p.

Flanigan, J.B., Sorensen, P.A., and Tucker, M.A., 1995, Use of hydrogeologic data in recharge pond design, vol. II in A.I. Johnson, and R.D. Pyne, eds., Artificial recharge of ground water: New York, American Society of Civil Engineers,., p.139-148.

Freeze, R.A. and Cherry, J.A., 1979, Groundwater: Englewood Cliffs, New Jersey, Prentice-Hall, p. 367-370.

Pruess, K., 1991, TOUGH2-A general-purpose numerical simulator for multiphase fluid and heat flow: Lawrence Berkeley National Laboratory Rep. LBL-29400, 102 p.

Shaikh, A., Bell, R.B., Ford, M.E., and Stockton, S.P., 1995, Feasibility of recharge by surface spreading, vol. II in A.I. Johnson, and R.D. Pyne, eds., Artificial recharge of ground water: New York, American Society of Civil Engineers, p. 159-167. 
(A)

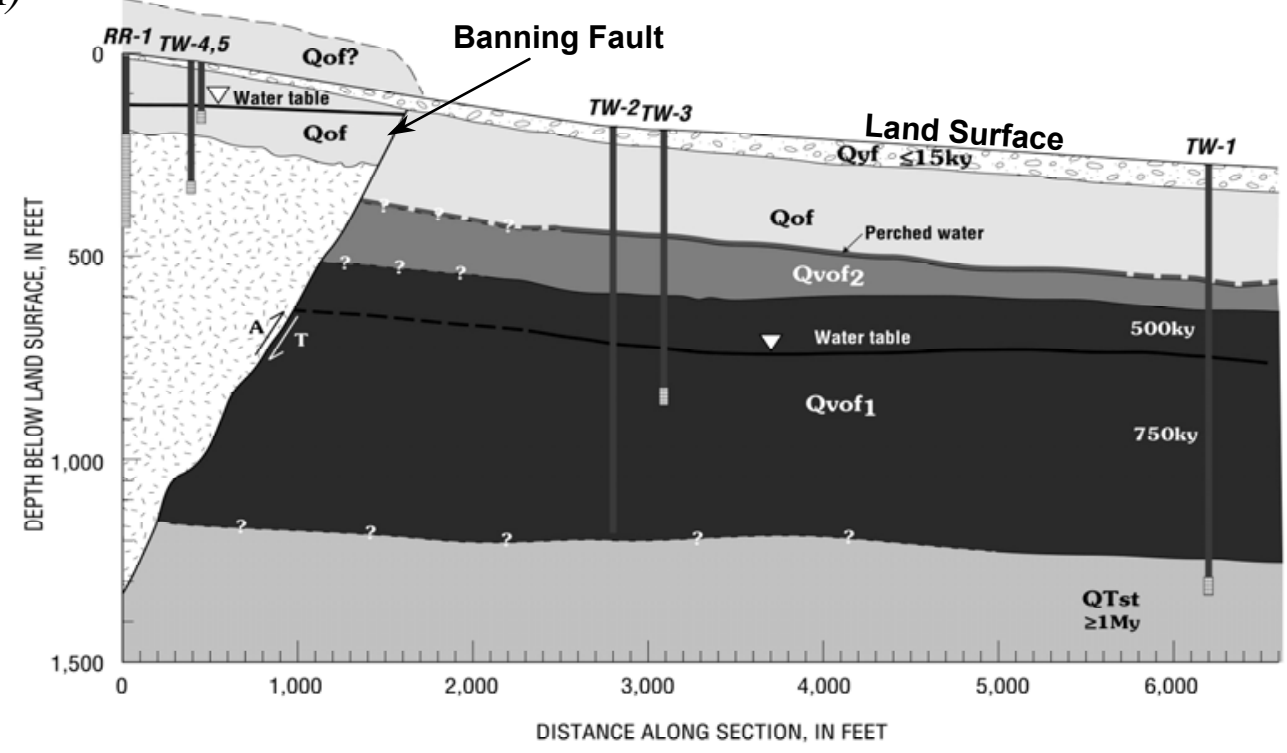

(B)

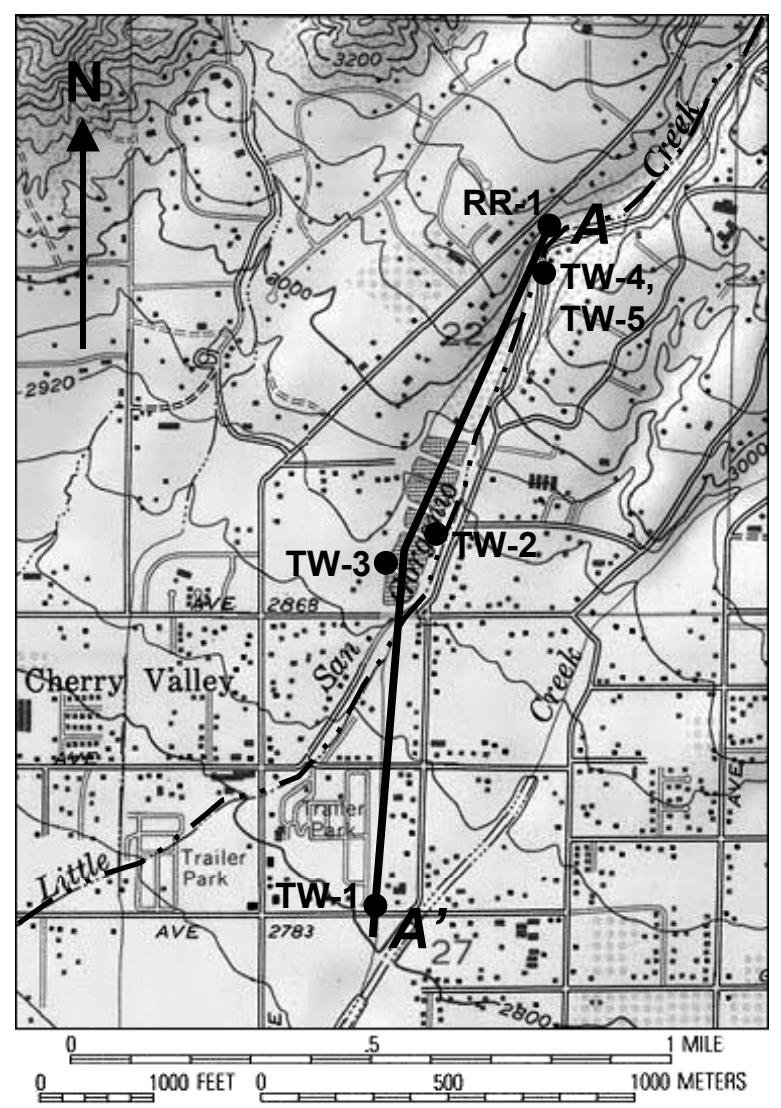

EXPLANATION

Alluvial deposits

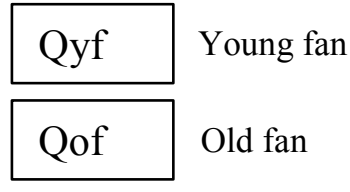
Qvof2 Very old fan upper

Qvof1 Very old fan
lower

\section{QTst San Timoteo formation}

$\mathrm{ky}=$ thousands of years

Figure 1. Conceptual cross section of the layered stratigraphy $(A)$ and the relative location of the cross section and near-surface spreading basins to features of the San Gorgonio Pass area, California $(B)$. 


\title{
The Role of Saturated Flow in Artificial Recharge Projects
}

\author{
Steven P. Phillips (sphillip@usgs.gov) \\ U.S. Geological Survey, Placer Hall, 6000 J Street, Sacramento, California 95819-6129
}

\section{Introduction}

The goal of most artificial recharge projects is to convey water to the saturated zone. Evaluation of the viability of proposed projects and of the effectiveness of existing projects requires an understanding and predictive capability of their hydraulic and chemical effects. This abstract focuses on the potential hydraulic consequences of altering the saturated flow system through artificial recharge, which are largely controlled by the geologic and hydrologic characteristics of the aquifer system. A combination of field, laboratory, analytical, and simulation methods generally are used to develop an understanding of the hydrogeologic system as a basis for predicting potential consequences. Optimization techniques may be coupled with predictive models of ground-water flow and other processes to create an effective tool for planning and management of artificial recharge projects. Pre-project and long-term monitoring of key aspects of a flow system is an essential part of a successful management plan.

\section{Potential Hydraulic Effects of Artificial Recharge Projects}

Artificial recharge projects are undertaken for many purposes in a variety of aquifer systems and associated hydraulic conditions. Regardless of the initial distribution and trend of hydraulic heads in these systems, artificial recharge will alter these heads and associated conditions. Depending on the purpose of the artificial recharge project, heads may show seasonal fluctuations or relatively long-term trends. Potential hydraulic effects of these changes, which may be positive, negative, or neutral include change in aquifer storage; changes in base flow in streams and on the rates of gain or loss from other surface-water bodies; changes in interbasin flow, evapotranspiration, and other sources of recharge and discharge; altered rates of land-surface deformation (subsidence and uplift) and saltwater intrusion; changes in interaquifer flow; induced seismicity; and several effects related to a shallow water table, including flooding of, and structural damage to basements and other surface and subsurface structures; surface flooding from flowing wells; increased susceptibility to liquefaction; and mobilization of salts or other near-surface contaminants. Mixing of water from different sources clearly has chemical and microbiological effects, which are discussed elsewhere in these proceedings.

Although prediction of many of these effects can be fairly straightforward in the vicinity of artificial recharge projects, experience has shown that more widespread and long-term effects are sometimes difficult to foresee. The city of San Bernardino in southern California, for example, is several miles down-gradient from multiple artificial recharge projects that have successfully raised water levels and reduced pumping costs for groundwater users near these projects. An unfortunate side effect of these operations, combined with above-average rainfall, was large increases in water levels underlying the city and associated severe structural and water-related damages (Danskin and Freckleton, 1992). This, as well as other examples, emphasize the importance of regional characterization of the saturated zone, which has the potential to transmit pressure rapidly over large distances and can support flow rates that may affect ground-water flow on a regional scale during the life of an artificial recharge project.

\section{Geologic and Hydrologic Characterization}

Characterization of the geology is important in determining the viability of an artificial recharge project, particularly where significant lateral and (or) vertical ground-water flow is required between recharge and discharge locations. Key features such as faults with significant offset, folds, and areally extensive coarse- or fine-grained sedimentary units can exert dominant controls on a flow system and on the fate of water from artificial recharge projects. This point is emphasized by experience in the Rialto-Colton basin in southern California, where imported surface water was recharged through surface ponds upgradient of a group of production wells intended to capture the recharge. Subsequent investigations revealed a low-permeability fault between the ponds and the wells, and 
geochemical evidence and predictive simulations suggest the wells will receive little hydraulic benefit from the artificial recharge project (Woolfenden and Koczot, 2001).

Methods for geologic characterization include surficial mapping; drilling and core analysis; borehole, surface, and aerial geophysics; sequence stratigraphy; geostatistical analysis of lithology; and others. The degree of geologic investigation required for a given project likely will depend on the availability of existing information, the complexity of the geology, and the scale of the project. Given the importance of understanding the continuity between the recharge and discharge locations, a tightly focused investigation is often warranted. For small-scale investigations, cross-hole tomography may be used to generate three-dimensional interpolations between boreholes of various physical characteristics. Advanced techniques for collecting and analyzing continuous core samples are among the other options for small-scale investigations.

Hydrologic considerations for the saturated-flow component of an artificial recharge project typically include the distribution of head and stress prior to and during project operations, hydraulic properties, the fate of artificially recharged water, and offsite effects. Determination of the initial and transient head distribution at key locations in the aquifer system commonly is accomplished using standard electronic monitoring equipment in some combination of wells and piezometers. Continuous (frequent sample rate, for example, hourly) data are far more useful than periodic data; collecting barometric data at the same high frequency is recommended, because it can be used to remove the barometric effect from the water-level record, or, in some cases, to estimate the vertical hydraulic diffusivity of the aquifer (Rojstaczer, 1988; Quilty and Roeloffs, 1991). Differential microgravity measurements have been used in surficial (Pool and Hatch, 1991) and injection-based artificial recharge projects (James F. Howle, U.S. Geological Survey, written commun., 2001) to estimate specific yield when coupled with water-level measurements, and to estimate changes in the position of the water table in the absence of wells. This and other geophysical techniques can be an effective means for increasing the sample density of a traditional waterlevel network.

The prediction of saturated flow during artificial recharge projects requires information on the distribution of stress, or recharge and discharge. These stresses can include a variety of natural and artificial processes that can be measured in a variety of ways. With respect to artificial recharge, surface applications of known volumes of water are converted to recharge rates over an area, which are determined through analysis of unsaturated-zone flow (see Alan Flint's abstract "The Role of Unsaturated Flow in Artificial Recharge Projects" in these proceedings) and (or) measured system responses. The vertical distribution of recharge through injection wells may be inferred using head and chemistry data from multi-level piezometers, and (or) measured directly using existing and recently developed methods for measuring vertical profiles of flow and chemistry in wells (Izbicki and others, 1998; Izbicki and others, 1999). Discharge through wells can be measured in the same way; most forms of surface discharge can be monitored using standard methods.

The hydraulic properties of an aquifer system, along with the distribution of stress, determine the direction and rate of saturated flow. The estimation of storage and transmissive properties of parts the saturated aquifer system generally is done through some combination of laboratory analysis of core samples, borehole geophysics and velocity logs, multi- or single-well aquifer tests, as well as other methods. Extrapolation of this local information to the region of interest generally involves incorporation of regional geologic information and simulation of the flow system, often iteratively. Powerful geostatistical methods have been developed and used to characterize the geology, quantify the range of possible conceptualizations, and express it in a hydrogeologic framework (Fogg and others, 2000).

Given the distribution of head, stress, and hydraulic properties, simulation models can be developed to help address the fate of artificially recharged water and offsite effects. The ability to recover some percentage of recharged water, often referred to as the recovery efficiency, varies widely and is sometimes an important criterion for project success. If recovery efficiency is important, tracer tests can be used as a direct measure of recovery, and can further constrain the hydraulic properties of the simulation model. Particle tracking or solute transport modeling can address the fate of recharged water that is not recovered. Monitoring and simulation are both used to address offsite effects; however, simulation can also be used to design an efficient monitoring network prior to full-scale implementation. 


\section{Optimization, Management, and Monitoring of Artificial Recharge Projects}

Successful planning and management of an artificial recharge project often requires consideration of many water management objectives, water routing capabilities, economics, offsite effects, as well as other factors. Optimization techniques are designed to identify an optimal way to meet an objective given a set of constraints. The linkage of a predictive ground-water flow model with optimization techniques, or a simulation/optimization model, allows for simultaneous consideration of the flow system and physical and (or) economic constraints determined by water-resource managers.

Simulation/optimization models have been applied to ground-water problems for decades (Gorelick, 1983; Yeh, 1992; Wagner, 1995; Ahlfeld and Mulligan, 2000), and have been used to plan and manage artificial recharge projects (Danskin and Gorelick, 1985; Reichard, 1995; Mosch, 1998; Dreher and Gunatilaka, 1998; Basagaoglu and Marino, 1999). In Vienna, Austria, for example, infiltration of contaminants from the Danube River was severely degrading ground-water quality. A simulation/optimization model was developed to minimize river infiltration through real-time control of 21 pairs of injection/extraction wells on the basis of continuous measurements of water levels and water quality in 190 ground-water monitoring wells and 20 surface-water sites (Dreher and Gunatilaka, 1998). This complex application has been very successful.

Monitoring of hydraulic conditions prior to and during an artificial recharge project is an essential part of a management plan, and often is an integral part of project operations. Measurement of project performance is clearly one goal of a monitoring program. A second goal is to provide the information needed for future improvement of predictive modeling capabilities and adjustment of optimization constraints. Reduced uncertainty in model results translates directly to increased confidence in management decisions based on these models.

\section{References Cited}

Ahlfeld, D.P., and Mulligan, A.E., 2000, Optimal management of flow in groundwater systems: San Diego, Calif., Academic Press, $185 \mathrm{p}$.

Basagaoglu, Hakan, and Marino, M.A., 1999, Joint management of surface and ground water supplies: Ground Water, v. 37, no. 2, p. 214-222.

Danskin, W.R., and Freckleton, J.R., 1992, Ground-water-flow modeling and optimization techniques applied to high-ground-water problems in San Bernardino, California, in Subitzky, Seymour, ed., Selected papers in the hydrologic sciences 1988-92: U.S. Geological Survey Water-Supply Paper 2340, p. 165-177.

Danskin, W.R., and Gorelick, S.M., 1985, A policy evaluation tool: Management of a multiaquifer system using controlled stream recharge: Water Resources Research, v. 21, no. 11, p. 1731-1747.

Dreher, J.E., and Gunatilaka, A., 1998, Ground water management system in Vienna - an evaluation after three years of operation: in Peters, Jos H. ed. Artificial Recharge of Ground Water, Proceedings of the Third International Symposium, Amsterdam, Netherlands, 1998, A.A. Balkema, Rotterdam, Netherlands and Brookfield, VT, p.167-172.

Fogg, G.E., Carle, S.F., and Green, Christopher, 2000, Connected-network paradigm for the alluvial aquifer system: in Zhang, D., and Winter, C.L., eds., Theory, modeling, and field investigations in hydrogeology: a special volume in honor of Shlomo P. Neuman's $60^{\text {th }}$ birthday: Boulder, Colo., Geological Society of America Special Paper 348, p. 25-42.

Gorelick, S.M., 1983, A review of distributed parameter groundwater management modeling methods: Water Resources Research, v. 19, no. 2, p. 305-319.

Izbicki, J.A., Christensen, A.H., and Hanson, R.T., 1999, U.S. Geological Survey combined well-bore flow and depth-dependent water sampler: U.S. Geological Survey Fact Sheet 196-99, 1 p. 
Izbicki, J.A., Danskin, W.R., and Mendez, G.O., 1998, Chemistry and isotopic composition of ground water along a section near the Newmark area, San Bernardino County, California: U.S. Geological Survey WaterResources Investigations Report 97-4179, 27 p.

Mosch, M.J.M., 1998, Dynamic simulation model for water management of a large-scale artificial recharge system: in Peters, Jos H. ed., Artificial recharge of ground water, Proceedings of the Third International Symposium, Amsterdam, Netherlands, 1998: A.A. Balkema, Rotterdam, Netherlands and Brookfield, VT, p. $15-20$.

Pool, D.R. and Hatch, M., 1991, Gravity response to storage change in the vicinity of infiltration basins: Proceedings of the Fifth Biennial Symposium on Artificial Recharge of Grondwater, Tucson, Arizona, p. 171.

Quilty, E.G., and Roeloffs, E.A., 1991, Removal of barometric pressure response from water-level data: Journal of Geophysical Research, v. 96, no. B6, p. 10209-10218.

Reichard, E.G., 1995, Groundwater-surface water management with stochastic surface water supplies: A simulation-optimization approach: Water Resources Research, v. 31, no. 11, p. 2845-2865.

Rojstaczer, Stuart, 1988, Determination of fluid flow properties from the response of water levels in wells to atmospheric loading: Water Resources Research, v. 24, no. 11, p. 1927-1938.

Wagner, B.J.,1995, Recent advances in simulation-optimization groundwater management modeling: Reviews of geophysics, supplement, U.S. National report to International Union of Geodesy and Geophysics, 1991-94, p. 1021-1028.

Woolfenden, L.R., and Koczot, K.M., 2001, Numerical simulation of ground-water flow and assessment of the effects of artificial recharge in the Rialto-Colton basin, San Bernardino County, California: U.S. Geological Survey Water-Resources Investigations Report 00-4243, 147 p.

Yeh, W.G., 1992, Systems analysis in groundwater planning and management: Journal of Water Resources Planning and Management, v. 118, no. 3, p. 224-237. 


\title{
Organic Matter in Ground Water
}

\author{
George Aiken (graiken@usgs.gov) \\ U.S. Geological Survey, 3215 Marine Street, Boulder, Colorado 80303
}

\begin{abstract}
An important element of artificial recharge is the introduction of potentially reactive organic matter into an aquifer. Geochemical interactions between this organic matter and aquifer solids inorganic constituents in the subsurface can result in fractionation of the organic matter thereby altering its composition and the surfaces of aquifer solids. In addition, varying the amount and nature of the organic material in the aquifer may be a significant factor in controlling a number of geochemical, microbial and environmental processes. Due to its reactive nature, a thorough understanding of the biogeochemistry of organic matter in the aquifer is warranted. In this paper, a description of the factors that control the nature, transport and reactivity of organic matter in the subsurface will be presented.
\end{abstract}

Organic matter in groundwater plays important roles in controlling geochemical processes by acting as proton donors/acceptors and as $\mathrm{pH}$ buffers, by affecting the transport and degradation of pollutants, and by participating in mineral dissolution/precipitation reactions. Dissolved and particulate organic matter may also influence the availability of nutrients and serve as a carbon substrate for microbially mediated reactions. Numerous studies have recognized the importance of natural organic matter in the mobilization of hydrophobic organic species, metals (e.g. $\mathrm{Pb}, \mathrm{Cd}, \mathrm{Cu}, \mathrm{Zn}, \mathrm{Hg}$, and $\mathrm{Cr}$ ), and radionuclides (e.g. Pu, Am, $\mathrm{U}$, and $\mathrm{Co}$ ). Many contaminants that scientists view as virtually immobile in aqueous systems can interact with dissolved organic carbon or colloidal organic matter, resulting in migration of hydrophobic chemicals far beyond distances predicted by structure/activity relationships. Although organic matter is often present in low concentrations in subsurface systems, this organic matter can exhibit significant reactivity with contaminants. In addition, these compounds are reactive substances that are potential precursors for the formation of disinfection by-products resulting from water treatment practices.

Organic matter in surface and groundwater is a diverse mixture of organic compounds ranging from macromolecules to low molecular weight compounds such as simple organic acids and short-chained hydrocarbons. Historically, organic matter in natural waters has been arbitrarily divided into dissolved (DOC) and particulate organic carbon (POC), based on filtration through a $0.45 \mu$ filter. No natural cutoff exists between these two fractions and the distinction is arbitrary, based on the filtration of the sample. The definition of terms, therefore, is operational. Overlapping the dissolved and particulate fractions is the colloidal fraction, which consists of suspended solids that are operationally considered solutes. Colloidal organic matter in natural waters is composed of living and senescent organisms, cellular exudates, and partially-to-extensively degraded detrital material, all of which may be associated with mineral phases. Generally, DOC is in greater abundance than POC, accounting for approximately $90 \%$ of the total organic carbon of most waters.

Microbial degradation of organic matter results in the formation of many of the compounds that comprise DOC, especially non-volatile organic acids that dominate the DOC in most aquatic environments. Many of these organic acids are considered refractory because the rates of subsequent biodegradation are slower than for other fractions or classes of organic matter. Organic matter derived from different source materials has distinctive chemical characteristics associated with those source materials. Organic matter derived from higher plants, for instance, has been found to have relatively large amounts of aromatic carbon, is high in phenolic content, and low in nitrogen content. Microbially-derived organic matter (from algae and bacteria), on the other hand, has greater nitrogen content, and low aromatic-C and phenolic content. In ground water, there are 3 main natural sources of organic matter: organic matter deposits such as buried peat, kerogen and coal; soil and sediment organic matter; and organic matter present in waters infiltrating into the subsurface from rivers, lakes and marine systems. The relative contributions of these sources of organic matter varies between different water bodies, but there is presently no way to quantify this variation based on chemical characterization of the organic matter. Once in the system, microbial processes continue to slowly alter the structure and chemical reactivity of the organic matter.

A number of significant, albeit poorly understood, mechanisms can be responsible for the transport or retention of organic molecules in the subsurface. Once in the system, organic compounds, whether they be 
anthropogenic or naturally derived, can be truly dissolved, associated with immobile particles or associated with mobile particles. Mobile particles include DOC, DOC-iron complexes and colloids. For an organic compound, each state is related to the other states through equilibrium partitioning and air/water exchange. The magnitude of the partitioning coefficients and the abundance of sorbents determine the mechanisms and enhancement of transport for a particular organic compound. Regardless of environment, chemical reactivity and speciation will be controlled by thermodynamics and reaction kinetics.

Application of chromatographic theory to subsurface transport can aid in understanding and quantifying the chemical processes in subsurface systems. Chromatography is essentially the transport of a chemical in a mobile fluid phase through a column packed with a stationary phase. A chemical introduced at the beginning of this column moves at a rate proportional to the average velocity of the fluid and inversely proportional to the strength and nature of sorptive interactions with the stationary phase. These interactions include ionic and complexation interactions, hydrogen bonding, van der Waal's interactions, and equilibrium partitioning. In a ground-water system, the geologic matrix, representing the stationary phase, generally consists of sand grains coated with organic matter. The mobile phase is the water, which can contain significant quantities of dissolved organic and inorganic chemicals. Organic compounds move through the system as a result of the flow rate of water and the strength and nature of interactions with the stationary phase. The nature and distribution of organic matter in the system is determined, to a large extent, by the interactions between the various phases in the environment.

Although little is known about the nature of the solid-phase coatings, it is important to recognize that the surfaces of the stationary particles have a profound effect on their sorptive properties for organic molecules. Almost all stationary particle surfaces are covered with an organic coating that imparts a negative charge to the surface. A sorptive interaction between organic compounds and stationary phases removes the DOC from solution and changes the surface of the particles. This process is a function of the chemical properties of the DOC, the particle-size distribution, and the chemistry of the ground water. Positively charged organic solutes are readily removed from the dissolved phase by cation exchange, which can be a significant sorption mechanism. Organic solutes that may exist as cations in natural waters include amino acids and polypeptides. Hydrophilic neutral (e.g carbohydrates, alcohols) and low molecular weight anionic organic compounds (e.g. organic acids) are retained the least by aquifer solids. Hydrophobic organic compounds interact strongly with the organic matter associated with the solid-phase. These interactions are controlled, in part, by the nature of the organic coatings, especially with respect to its polarity and aromatic carbon content. Interactions of hydrophobic organic compounds with stationary particles can result in strong binding and slow release rates of these compounds.

\section{Selected References}

Aiken, G. R., McKnight, D. M., Wershaw, R. L., and MacCarthy, P., eds., 1985, Humic Substances in Soil, Sediment, and Water: Geochemistry, Isolation, and Characterization: John Wiley, New York, 692p.

Aiken, G. R., and Cotsaris, E., 1995, The Influence of Soil Properties and Hydrology on the Nature of Organic Matter in Aquatic Systems and Drinking Water Supplies: Journal of the American Water Works Association, vol. 87, pp. 36-45.

Antweiler, R. C. and Drever, J. I., 1983, The weathering of late Tertiary volcanic ash: importance of organic solutes, Geochimica et Cosmochimica Acta: Vol. 47, pp. 623-629.

Davis, J. A., 1982, Adsorption of natural dissolved organic matter at the oxide/water interface. Geochimica et Cosmochimica Acta: Vol. 46, pp. 2381-2393.

Hoch, A.R., Reddy, M.M., and Aiken, G.R., 2000, Calcite crystal growth inhibition by humic substances: Geochimica et Cosmochimica Acta, Vol. 64, pp. 61-72.

Larson, R. A. and Weber, E. J., 1994, Reaction Mechanisms in Environmental Organic Chemistry: Lewis Publishers, Boca Raton, Florida, 433 p. 
Luthy, R. G., Aiken, G.R., Brusseau, M. L., Cunningham, S. D., Gschwend, P. M., Pignatello, J. J., Reinhard, M., Traina, S. J., Weber, W. J., and Westall, J. C., 1997, Sequestration of hydrophobic organic contaminants by geosorbents: Environmental Science and Technology, Vol. 31, pp. 3341-3347.

McKnight, D. M., Bencala, K. E., Zellweger, G. W., Aiken, G. R., Feder, G. L., and Thorn, K. A., 1992, Sorption of dissolved organic material by hydrous aluminum and iron oxides occurring at the Confluence of Deer Creek with the Snake River, Summit County, Colorado: Environmental Science and Technology, vol. 26, pp. 1388-1396.

Meier, M., Namjesnik-Dejanovic, K., Maurice, P., Chin, Y.P., and Aiken, G. R., 1999, Fractionation of aquatic natural organic matter upon sorption to goethite and kaolinite: Chemical Geology, Vol. 157, pp. $275-284$.

Schwarzenbach, R. P., Giger, W., Hoehn, E. and Schneider, J. K., 1983, Behavior of organic compounds during infiltration of river water to groundwater: Environmental Science and Technology, Vol. 17, pp. 472-479.

Schwarzenbach, R. P., Gschwend, P. M., and Imboden, D. M., 1993, Environmental Organic Chemistry: John Wiley \& Sons, New York, New York, 681 p.

Thorn, K. A. and Aiken, G. R., 1998, Biodegradation of crude oil into nonvolatile organic acids in a contaminated aquifer near Bemidji, Minnesota: Organic Geochemistry, Vol. 29, pp. 909-931. 


\title{
Processes Controlling Attenuation of Dissolved Organic Matter in the Subsurface
}

\author{
Jerry A. Leenheer (leenheer@usgs.gov) \\ U.S. Geological Survey, P.O. Box 25046, MS 408, Denver Federal Center, Lakewood, Colorado 80225
}

\begin{abstract}
The four major processes that directly control attenuation of dissolved organic matter (DOM) in the subsurface are adsorption and/or coprecipitation, biodegradation, and dilution. Factors that indirectly control DOM attenuation are groundwater redox state and $\mathrm{pH}$ (affects adsorption/precipitation and biodegradation); nutrient availability (affects biodegradation and redox); and rainfall, snowmelt, recharge, and evapotranspiration (affects dilution and precipitation).

DOM attenuation by adsorption (reaction with soil and aquifer surfaces) and/or precipitation (with groundwater cations such as aluminum, calcium and iron) is most obviously evidenced by soil podzolization processes in which DOM derived from oxidation of surface vegetation leaches aluminum, iron, manganese, and clay colloids from the albic horizon followed by precipitation (caused by $\mathrm{pH}$ and Eh changes) of DOM/metal complexes and clays in the underlying spodic horizon (Soil Conservation Service, 1975). Soil podzolization occurs in humid environments whereas in more arid environments, calcic horizons tend to form that coprecipitate DOM. A study (Alsmadi and Fox,2000) of soil aquifer treatment (SAT) of reclaimed water (tertiary-treated wastewater) in Phoenix, Arizona found that SAT resulted in doubling the amount of organic matter (from 14 to about $28 \%$ ) that was associated with iron, manganese, and carbonate coatings on aquifer surfaces that formed during SAT treatment. Adsorption and precipitation processes reduced DOM by greater than $90 \%$ during infiltration of "black waters" in northern Florida through karst sinkholes into the Upper Floridian limestone aquifer (Rostad et al., 2000).
\end{abstract}

DOM components, such as fulvic acid derived from tannins and lignins, are removed by ligand-exchange adsorption on aluminum, iron, and manganese sesquioxide coatings on mineral surfaces (Leenheer, 1991) whereas fulvic acid derived from terpenoid resins are not removed by sorption on these sesquioxides (unpublished research, Leenheer, 2002). The presence of clustered carboxylic acids in fulvic acid structures is necessary for fulvic acid adsorption/precipitation with calcium, iron, and manganese because of the formation of polydentate chelate complexes. These structures are present in fulvic acid derived from tannins and lignin (Leenheer et al., 1998), but not in fulvic acid derived from terpenoid resins such as was found in the Norman landfill (unpublished research, Leenheer , 2002).

Peptidoglycan colloids derived from bacterial cell walls comprise $30-40 \%$ of the DOM in many natural surface-waters (Leenheer et al., 2000) and 40\% in reclaimed water (Leenheer et al., 2001). When this reclaimed water was basin-infiltrated in Los Angeles County, California., this colloidal DOM was quantitatively removed in the first 1-foot of infiltration. Similar results were observed during infiltration of Santa Ana River in Anaheim Lake in Orange County, California (Leenheer, unpublished research, 2002). The mechanism of removal of these peptidoglycan colloids is believed to be adsorption on mineral surfaces as biodegradable algal cells were observed to infiltrate over $200 \mathrm{ft}$ below Anaheim Lake. The sorption mechanism for these colloids is hypothesized to be a combination of electrostatic interactions (basic positively-charged lysine unit on peptide chain with negativelycharged mineral surfaces) and hydrogen bonding of amide structures (peptides and $\mathrm{N}$-acetyl amino sugars) with mineral oxides and hydroxides (Leenheer, 1991).

Biodegradation processes can also be subdivided into colloidal DOM biodegradation and truly dissolved DOM biodegradation. The colloidal DOM that adsorbs at the bottom of basins used to infiltrated reclaimed water is a component of the biologically active "schmutzdecke" organic layer where aerobic biodegradation removes about $25 \%$ of the DOC during the first $10 \mathrm{~cm}$ of infiltration (Quanrud et al., 1996). Additional reductions in truly dissolved DOC over longer flow-paths and time periods result in overall DOC reductions from 48 to $90 \%$ (Bower et al., 1974; Idelovitch and Michail, 1984; Wilson et al., 1995). These reductions in DOM result from a combination of adsorption and biodegradation. 
A combination of low dissolved oxygen concentrations in groundwater and organic structures resistant to biodegradation has resulted in sulfonated anionic surfactant metabolites of LAS being stable to biodegradation over long time periods and flow paths in infiltrated sewage effluents at Cape Cod, Ma. (Field et al., 1992) and Los Angeles, Ca (Leenheer et al., 2001). The greater DO concentrations in groundwater infiltrated from the Santa Ana River, Orange County, California is probably responsible for the more efficient biodegradation of surfactant metabolites and DOC at this site (Ding et al., 1999, Leenheer, unpublished research, 2002). Aliphatic alicyclic rings are structural components of DOM that are most resistant to biodegradation (Trudgill, 1984) and are found in LAS metabolites such as dialkytetralin sulfonates (Field et al., 1992) and terpenoid resin acids. However, both DOC attenuation data and spectral characterization of DOM fractions isolated from infiltrated Santa Ana River water at the Orange County study site indicate aerobic biological degradation of aliphatic alicyclic rings of both DATS and terpenoid acids (Leenheer, unpublished research, 2002).

DOM attenuation by dilution can be assessed by comparing various conservative tracers (bromide, chloride, sulfate, boron, tritium, conductivity) that occur in infiltrating water versus receiving groundwater (Anders and Schroeder, 1998; Leenheer et al., 2001). A unique tracer such as sulfur hexafluoride can also be added to infiltrating water (Gamlin et al., 2001). The conservative component of DOM in infiltrated water can be identified and differentiated from native ground-water DOM at the compound-class level of identification by a combination of infrared and ${ }^{13} \mathrm{C}$-nuclear magnetic resonance spectral analyses, ${ }^{14} \mathrm{C}$ age dating of DOM isolates, and ${ }^{13} \delta \mathrm{C}$ isotope analyses of DOM isolates (Leenheer et al., 2001). This comprehensive study of DOM attenuation at various points and times in the infiltration flow-path was able to differentiate the various DOM attenuation processes by assessing

variations of dissolved constituents with time in the source water, assessing dissolved constituents in upgradient and downgradient uncontaminated groundwaters, and by applying multiple, independent analytical techniques to characterize DOM and various inorganic tracers.

\section{References}

Alsmadi, B.M., and Fox, P., 2000, Effect of soil aquifer treatment (SAT) on soil components and soil micromorphology. Proceedings First World Water Congress of the International Water Association, Paris, France, pp. 174-181.

Anders, R., and Schroeder, R.A., 1998, Correlations between various water-quality indicators of recharged recycled water in production wells in Los Angeles County, California. American Geophysical Union Meeting, Boston, MA, May 26-29; EOS Transaction Supplement, April 28, 1998, Abstract H61B-23, p. S141.

Bower, H., Lance, J.C., and Riggs, M.S., 1974, High rate land treatment II: Water quality and economic aspects of the Flushing Meadows Project. J. Water Pollution Control Federation, v. 46, p. 844-859.

Ding, W.-H., Wu, J., Semadeni, M., Reinhard, J., 1999, Occurrence of wastewater indicators in the Santa Ana River and impacted into groundwater. Chemosphere, v. 39, p. 1781-1794.

Field, J.A., Leenheer, J.A., Thorn, K.A., Barber, L. B., Rostad, C., Macalady, D. L., and Daniel, S.R., 1992, Identification of persistent anionic surfactant-derived chemicals in sewage effluent and groundwater. $J$. Contaminant Hydrology, v. 9, p. 55-78.

Gamlin, J.D., Clark, J.F., Woodside, G., and Herndon, R., 2001, Large-scale tracing of ground water with sulfur hexafluoride, J. Environmental Engineering, February, p. 171-174.

Idelovitch, I., and Michail, M., 1984, Soil-aquifer treatment-A new approach to an old method of wastewater reuse. J. Water Pollution Control Federation, v. 56, p. 936-943.

Leenheer, J. A., 1991, Organic substance structures that facilitate contaminant transport and transformations in aquatic sediments: Chaper 1 in Organic Substances and Sediments in Water, Humics and Soils, (R. A. Baker, ed.), Chelsea, Michigan, Lewis Publishers, v. 1, p. 3-22. 
Leenheer, J.A., Brown, G.K., MacCarthy, P., and Cabaniss, S.E., 1998, Models of metal-binding structures in fulvic acid from the Suwannee River: Environmental Science and Technology, v. 32, p. 2410-2416.

Leenheer, J. A., Croue, J.-P., Benjamin, M., Korshin, G. V., Hwang, C. J., Bruchet, A., and Aiken, G., 2000, Comprehensive isolation of natural organic matter for spectral characterization and reactivity testing, Chapter 5 in Natural Organic Matter and Disinfection By-Products, (S.E. Barrett, S. W. Krasner, and G. Amy), Eds., American Chemical Society Symposium Series 761, American Chemical Society, Wash. D. C., pp. 68-83.

Leenheer, J.A., Rostad, C.E., Barber, L.B., Schroeder, R.A., Anders, R., and Davisson, M.L., 2001, Nature and chlorine reactivity of organic constituents from reclaimed water in groundwater, Los Angeles County, California. Environmental Science and Technology, v. 35, p. 3869-3876.

Quanrud, D.M., Arnold, R.G., Wilson, L.G., Gordon, H.J., Graham, D.W., and Amy. G.L., 1996, Fate of organics during column studies of soil aquifer treatment. J. Environmental Engineering, April, p. 314-321.

Rostad, C.E., Leenheer, J.A., Katz, B., Martin, B.S., and Noyes, T.I., 2000, Characterization and disinfection byproduct formation potential of natural organic matter in surface and ground waters from northern Florida, Chapter 11 in Natural Organic Matter and Disinfection By-Products (S.E. Barrett, S.W. Krasner, and G. Amy, Eds.), ACS Symposium Series 761, American Chemical Society, Wash. D.C., pp. 154-172.

Soil Conservation Service, U.S. Department of Agriculture, 1975, Horizons and properties diagnostic for the higher categories: Mineral Soils. Chapter 3 in Soil Taxonomy, Agriculture Handbook No. 436, U.S. Government Printing Office, Wash. D.C., pp. 13-64.

Trudgill, P.W., 1984, Microbial degradation of the alicyclic ring. In Microbial Degradation of Organic Compounds (D.T. Gibson, Ed.), Microbiology Series, Vol. 13, Marcel Dekker, New York, N.Y., pp. 131-180.

Wilson, L.G., Quanrud, D.M., Arnold, R.G., Amy, G.L., Gordon, H.J., and Conroy, A.D., 1995, Field and laboratory observations on the fate organics in sewage effluent during soil aquifer treatment. Proc. Artificial Recharge of Ground Water, II, ASCE, New York, N.Y. 


\title{
Fate of Disinfection By-products in the Subsurface
}

\author{
Colleen Rostad (cerostad@usgs.gov) \\ U.S. Geological Survey, P.O. Box 25046, MS 408, Denver Federal Center, Lakewood, Colorado 80225
}

\begin{abstract}
Disinfection of drinking water involves adding chemicals to the source water to kill pathogens and viruses. These chemicals oxidize organic matter present and reduce odor and color of the water, but in the process produce disinfection by-products (Larson and Weber, 1994). Disinfection by-products can also be formed during wastewater disinfection. Concentrations of disinfection by-products (DBPs) in drinking water are subject to government regulations (Pontius, 1996, 1999). Prior to discharge, wastewater is heavily chlorinated and subsequently dechlorinated. Because of high dissolved organic carbon (DOC) concentrations in wastewater, high concentrations of DBPs result (Jekel and Roberts, 1980, Fujita et al, 1996). These are discharged into surface or groundwaters, where they may be diluted, volatized, or sorbed to nearby sediments. In wastewater discharged to surface waters, discharge permits usually limit free chlorine (due to sensitivity of aquatic organisms), rather than disinfection byproducts.
\end{abstract}

The quantity and speciation of DBPs, such as total organic halide (TOX) and trihalomethanes (THMs) can vary not only by water quality and disinfection conditions, but also by properties of the organic molecules that comprise the DOC (Croue et al., 1999). Natural organic matter characteristics of source waters, such as molecular weight distribution and humic content, can vary due to some geographical or source-related (surface vs. groundwater) differences (Owen et al, 1993).

Although much is known about disinfection processes and factors that influence by-product formation, less is known about their fate in the environment. Most groundwater recharge is done with chlorination-disinfected wastewaters. Studies have shown that in surface waters TOX is relatively non-volatile and conservative, whereas THMs volatilize. In groundwater assessments across the country, the most common contaminant found was chloroform (a prevalent chlorination by-product), possibly from municipal drinking water infiltration (Squillace et al., 1999). Ozone is rarely used to disinfect wastewaters, and therefore ozonated water is rarely used for recharge. Ozonation increases the biodegradability of natural organic matter, resulting in greater bacterial regrowth in ozonated waters without further biological treatment (Reckhow, 1999), which is a detriment to efficient recharge.

Effect of aquifer recharge on DBPs and their formation potential is important for eventual retrieval and potable use of the water (Bouwer, 1991, Asano, 1992; Pinholster, 1995). Groundwater recharge can be accomplished by surface spreading or direct injection. However, concerns about water quality and potential health hazards led to California issuing guidelines for groundwater recharge, recommending spreading over injection, disinfection prior to recharge, and minimization of DBPs (Crook et al, 1990). Groundwater recharge is more expensive using injection wells than infiltration basins (Bouwer, 1991).

In order to assess the effectiveness of wastewater treatment by groundwater recharge (soil aquifer treatment), two aspects are important: the fate of DBPs themselves, and changes in the DOC, which affect the disinfection by-product formation potential upon reuse. However, extensive studies on DOC fractionation and THM formation potential (Owen et al, 1993; Croue et al, 1999; Croue et al, 2000; Hwang et al, 2000) rarely are applied to groundwaters.

Initial studies on groundwater recharge by direct injection of reclaimed municipal wastewater found that although total organic carbon and THMs decreased, the TOX showed no retardation or sorption in the aquifer (Roberts et al, 1982). Using secondary and tertiary treated wastewater for aquifer recharge, a decrease of 50 percent of DOC and 40 percent of TOX was accomplished by shallow (20-ft) soil aquifer treatment, while the THMs volatilized in the recharge ponds prior to infiltration (Amy et al, 1993). Most removal occurred within the top meter of the surface. Higher molecular weight, humic material was preferentially removed by the soil aquifer treatment (Amy et al, 1993), as has been reported for granular activated carbon (Owen et al, 1993). Soil aquifer treatment at the same site using greater depths $(80-\mathrm{ft})$ reduced DOC by 92 percent and TOX by 85 percent (Wilson et al, 1995). Soil column studies with secondary effluent showed DOC removal of 56 percent for sandy loam, 48 percent for sand and 44 percent for silty sand (Quanrud et al, 1996a). While 48 percent of the DOC was removed with most removal 
near the surface, absorbable organic halide removal, assumed to be sorption, was only 17 percent, (Quanrud et al, 1996b).

Reclaimed water derived from secondary and tertiary treated wastewater has been discharged into spreading basins to recharge groundwater in Los Angeles County, California for 30 years. TOX and THM concentrations were determined in 1996 at the source, and down gradient with multilevel samplers located from 4 to 20 feet below the spreading basin. Elevated THMs and TOX were found below and in distant down-gradient wells (Barber et al, 1997). If TOX were sorbing out or degrading, it would decrease relative to DOC. The proportion of TOX to DOC remained consistent along the gradient sampled. There was also no decrease in THMs relative to TOX in the aquifer. Yield of TOX and THMs did not change significantly during infiltration (Leenheer et al, 2001). Therefore, precursors of disinfection byproducts in reclaimed water are not rapidly removed by soil aquifer treatment.

In twenty-three nearby production wells, TOX correlated with DOC with a linear correlation coefficient, $\mathrm{r}^{2}$, of 0.61 . In contrast, TOX correlated with UV absorbance at $254 \mathrm{~nm}$ with a much lower $\mathrm{r}^{2}$ of 0.42 . Specific UV (SUVA, ratio of UV absorbance to DOC) was much lower than other natural waters (Amy et al, 1987). On four of the production wells, total THM yield (ug THM formed per mg DOC in source) were low, compared to similar literature values (Rathbun, 1996). Non-purgeable TOX yield was consistently lower than other yields reported (Rathbun, 1996). The very low specific UV and low yields of THM and TOX indicate that the DOC is much less reactive with chlorine than commonly found in surface waters. Low reactivity would be expected from reclaimed water, which has been chlorinated and dechlorinated prior to release. Conclusions from these formation-potential studies were that the aquifer recharge was not contributing TOX or THM formation potential to this water during recharge.

An aquifer in northern Florida was investigated where the surface water connects to groundwater through limestone karst. Karst features, such as sinkholes, provide direct pathways for the flow of surface water into the unconfined aquifer. The surface water sources are referred to as blackwater streams due to the high concentrations of tannins and lignins. Formation potentials of the surface and groundwater were quite different. The DOC was fractionated to determine which specific fractions were the most reactive (Rostad et al, 2000b).

Two groundwater samples were dominated by hydrophobic acids, with minor amounts of the other fractions. Two surface water samples were dominated by hydrophobic acids and colloids, which made up about $75 \%$ of the DOC, and significant amounts of hydrophilic acids and tannins. About a third of the organic carbon was in the colloid phase. Surface waters were much more complex than the groundwaters, even though they are directly connected, and linked to each other. There was a dramatic decrease in DOC between the surface and ground waters, and the DOC in these waters are quite different chemically. TOX and THM production for the surface and ground waters indicated that the colloid and hydrophobic acid fractions were more reactive than the other fractions per milligram DOC.

SUVA is a commonly used indicator of formation potential based on UV absorbance (Minear and Amy, 1996). In comparison of TOX yield as a function of SUVA, at all four sites the hydrophilic acids and bases had greater yield than SUVA predicted. Hydrophobic acids, and hydrophobic neutrals were less reactive than SUVA predicted. When THM yield was compared to SUVA, at all four sites the THM formation potential was even more consistent in the trends of (1) hydrophilic acids and bases had greater yield than SUVA predicted; (2) Hydrophobic Acids, and hydrophobic neutrals were less reactive than SUVA predicted. Fractions of the DOC reacted to produce different disinfection by-product yields. The overall effect of limestone aquifer on DOC was that the high concentrations of DOC present in the surface waters were either sorbed or precipitated out by the limestone karst during infiltration.

Formation potentials were determined for 24 hours and for 7 days in waters entering and exiting a demonstration constructed wetland near Phoenix, Arizona (Rostad, 2000b). In 24 hours, the DBPs were dominated by TOX. Although this water is chlorinated and dechlorinated prior to discharge to the wetland, reactivity of the remaining DOC was greater than expected. Dissolved organic carbon produced by the wetland was highly reactive in producing THMs. After 7 days, the formation of THMs dominated over TOX. In seven days the water exiting the wetland formed slightly less THMs than TOX, although the amounts were greater. Because formation of THMs increases after the first 24 hours, utilities prefer to keep residence time down to 24 hours in distribution systems. 
Compared to the incoming wastewater, the constructed wetland increased the formation potential of the water both for TOX and THMs.

In general, under soil aquifer treatment conditions, DOC and THMs decreased, but TOX showed less attenuation. Most removal occurred near the surface. Unlike constructed wetland treatment, formation potential of TOX and THMs was not increased by soil aquifer treatment.

\section{References}

Amy, G.L., Chakik, P.A., Chowdhury, Z.K., 1987, Developing models for predicting trihalomethanes formation potential and kinetics, J. American Water Works Association, 79(7), 89-97.

Amy, G., Wilson, L.G., Conroy, A., Chahbandour, J., Zhai, W., Siddiqui, M., 1993, Fate of chlorination byproducts and nitrogen species during effluent recharge and soil aquifer treatment (SAT), Water Environment Research, 65(6), 726-734.

Asano, T., 1992, Artificial Recharge of Groundwater with Reclaimed Municipal Wastewater: Current Status and Proposed Criteria, Water Sci. Tech. 25(12), 87-92.

Barber, L.B., Brown, G.K., Kennedy, K.R., Leenheer, J.A., Noyes, T.I., Rostad, C.E., Thorn, K.A., 1997, Organic contaminants that persist during aquifer storage and recovery of reclaimed water in Los Angeles County, California, Proceedings of the AWRA Symposium, Conjunctive Use of Water Resources: Aquifer Storage and Recovery, D. R. Kendall (Ed.), Long Beach, California, October 19-23, 1997.

Bouwer, H., 1991, Role of Groundwater Recharge in Treatment and Storage of Wastewater for Reuse, Water Sci. Tech. 24(9), 295-302.

Crook, J., Asano, T., Nellor, M.H., 1990, Groundwater recharge with reclaimed water in California. Water Environment \& Technology, 42-49.

Croue, J-P., Violleau, D., Labouyrie, L., 2000, Disinfection By-Product Formation Potentials of Hydrophobic and Hydrophilic Natural Organic Matter Fractions: A Comparison between a Low- and a High-Humic Water, Chapter 10 in Natural Organic Matter and Disinfection By-products: Characterization and Control in Drinking Water. American Chemical Society Symposium Series 761, American Chemical Society, Washington, D.C., 139-153.

Croue, J-P., Debroux, J-F., Amy, G.L., Aiken, G.R., Leenheer, J.A., 1999, Natural Organic Matter: Structural Characteristics and Reactive Properites, Ch. 4 in Formation and Control of Disinfection By-Products in Drinking Water, American Water Works Association, P.C. Singer, Ed., Denver, Colorado.

Fujita, Y., Ding, W-H., Reinhard, M., 1996, Identification of wastewater dissolved organic carbon characteristics in reclaimed wastewater and recharged groundwater, Water Environment Research, 68(5), 867-876.

Hwang, C.J., Sclimenti, M.J., Krasner, S.W., 2000, Disinfection By-Product Formation Reactivities of Natural Organic Matter Fractions of a Low-Humic Water, Chapter 12 in Natural Organic Matter and Disinfection By-products: Characterization and Control in Drinking Water. American Chemical Society Symposium Series 761, American Chemical Society, Washington, D.C., 173-187.

Jekel, M.R., Roberts, P.V., 1980, Total Organic Halogen as a Parameter for the Characterization of Reclaimed Waters: Measurement, Occurrence, Formation, and Removal, Environmental Science and Technology, 14(8), 970-975.

Leenheer, J.A., Rostad, C.E., Barber, L.B., Schroeder, R.A., Anders, R., Davisson, M.L., 2001, Determination of nature and chlorine disinfection by-products of organic constituents from reclaimed water in groundwater, Los Angeles County, California, Environmental Science and Technology, v. 35, 3869-3876. 
Larson, R.A., Weber, E.J, 1994, Reactions with disinfectants, Ch. 5 in Reaction Mechanisms in Environmental Organic Chemistry, Lewis Publishers, Boca Raton, FL.

Minear, R.A., Amy, G.L., 1996, Water Disinfection and Natural Organic Matter: History and Overview, in Water Disinfection and Natural Organic Matter: Characterization and Control, Minear, R.A., Amy, G.L., (Eds.) American Chemical Society, Washington, D.C., p1-9.

Owen, D.M., Amy, G.L., Chowdhry, Z.K., 1993, Characterization of Natural Organic Matter and Its Relationship to Treatability, AWWA Research Foundation, Denver, Colorado.

Pinholster, G., 1995, Drinking Recycled Water, Environmental Science and Technology, 29(4), 174A-179A.

Pomes, M.L., Larive, C.K., Thurman, E.M., Green, W.R., Orem, W.H., Rostad, C.E., Coplen, T.B., Cutak, B.J., Dixon, A.M., 2000, Sources and Haloacetic Acid/Trihalomethane Formation Potentials of Aquatic Humic Substances in the Wakarusa River and Clinton Lake near Lawrence, Kansas, Environmental Science and Technology, v. 34, 4278-4286.

Pontius, F.W., 1996, An Update of the Federal Regs, Journal of the American Water Works Association, 88(3), 3646.

Pontius, F.W., 1999, Regulation of Disinfection By-Products, Ch. 7 in Formation and Control of Disinfection ByProducts in Drinking Water, American Water Works Association, P.C. Singer, Ed., Denver, Colorado.

Quanrud, D.M., Arnold, R.G., Wilson, L.G., Conklin, M.H., 1996a, Effect of Soil Type on Water Quality Improvement during Soil Aquifer Treatment, Water Sci. Tech., 33(10-11), 419-431.

Quanrud, D.M., Arnold, R.G., Wilson, L.G., Gordon H.J., Graham, E.W., Amy, G.L., 1996b, Fate of Oganics during Column Studies of Soil Aquifer Treatment, J. Environmental Engineering, April, 314-321.

Rathbun, R.E., 1996, Disinfection byproduct Yields from the Chlorination of Natural Waters, Archives of Environmental Contamination and Toxicology, 31(3), 420-425.

Reckhow, D., 1999, Control of Disinfection By-Product Formation using Ozone, Ch. 9 in Formation and Control of Disinfection By-Products in Drinking Water, American Water Works Association, P.C. Singer, Ed., Denver, Colorado.

Roberts, P.V., Schreiner, J., Hopkins, G.D, 1982, Field Study of Organic Water Quality Changes during Groundwater Recharge in the Palo Alto Baylands, Water Research, 16, 1025-1035.

Rostad, C.E., Leenheer, J.A., Katz, B.G., Martin, B.S., Noyes, T.I., 2000a, Characterization and disinfection byproduct formation potential of natural organic matter in surface and ground waters from northern Florida, Chapter 11 in Natural Organic Matter and Disinfection By-products: Characterization and Control in Drinking Water. American Chemical Society Symposium Series 761, American Chemical Society, Washington, D.C., 154-172.

Rostad, C. E., Martin, B. S., Barber, L.B., Leenheer, J.A., and Daniel, S.R., 2000b, Effect of a constructed wetland on disinfection by-products: Removal processes and Production of precursors, Environmental Science and Technology, v. 34, 2703-2710.

Squillace, P.J., Moran, M.J., Lapham, W.W., Price, C.V., Clawges, R.M., Zogorski, J.S., 1999, Volatile organic compounds in untreated ambient groundwater of the United States, 1985-95: Environmental Science and Technology, v. 33, no. 23, p. 4176-4187.

Wilson, L.G., Amy, G.L., Berba, C.P., Gordon, H., Johnson, B., Miller, J., 1995, Water quality changes during soil aquifer treatment of tertiary effluent, Water Environment Research, 67(3), 371-376. 


\title{
Impact of Organic Contaminants on the Evolution of Aquifer Geochemistry
}

\author{
Isabelle M. Cozzarelli (icozzare@usgs.gov) \\ U.S. Geological Survey, 12201 Sunrise Valley Drive, Mail Stop 431, Reston, Virginia 20192
}

\section{Abstract}

Numerous studies of aquifers contaminated with organic compounds have demonstrated that the introduction of organic material results in significant changes in the aqueous and solid-phase chemistry. These changes are largely driven by the degradation of the organic compounds by indigenous microorganisms. A range of electron acceptors available in subsurface environments can be utilized by bacteria to mediate the oxidation of labile organic compounds. Dissolved oxygen is the most readily used electron acceptor. In the absence of oxygen, the oxidized forms of other inorganic species are used by microorganisms as electron acceptors. A sequence of reactions, in order of decreasing energy yield, is typically observed during the decomposition of organic matter in aquifers, reflecting the ecological succession of progressively less efficient modes of metabolism. The order of utilization of electron acceptors is typically dissolved $\mathrm{O}_{2}, \mathrm{NO}_{3}{ }^{-}, \mathrm{Mn}$ (IV)-solids, $\mathrm{Fe}$ (III)-solids, and dissolved $\mathrm{SO}_{4}{ }^{2-}$.

In most sand and gravel aquifers, Fe (III), as iron oxides, is abundant. Although less abundant, manganese oxides (Mn(IV)) are easily reducible by microorganisms. Organic matter oxidation coupled to Mn (IV) and Fe(III) reduction have resulted in the accumulation of high concentrations of dissolved $\mathrm{Fe}^{2+}$ and $\mathrm{Mn}^{2+}$ in ground water (Baedecker and Back, 1979; Chapelle and Lovley, 1992; Lyngkilde and Christensen, 1992; Baedecker et al., 1993). The absence of these oxides, or the depletion of microbially reducible Fe (III)-oxides in narrow zones in anoxic aquifers, has allowed sulfate reduction (e.g. at the Galloway site (Cozzarelli et al., 1999)) or methanogenesis (e.g. at the Bemidji site (Bekins et al., 2001 and Cozzarelli et al., 2001)) to occur at small spatial scales. In most aquifers, nitrate and sulfate are supplied during ground-water recharge by rainwater, by mixing with seawater, or by contamination of ground water with fertilizers. The reduction of nitrate and sulfate has resulted in the accumulation of reduced nitrogen species and sulfide in aquifers impacted by organic contaminants (e.g., Baedecker and Back, 1979; Baedecker and Cozzarelli, 1992).

Geochemical reactions may be complicated or obscured by the spatial or temporal scales at which they occur. Although organic degradation reactions may occur at a micro-scale, the products of these reactions become mixed in the groundwater, causing significant variations in the chemical character of the water and the aquifer material. Changes in the aquifer solids include formation of authigenic minerals, such as iron sulfides and iron carbonates (Baedecker et al., 1992; Cozzarelli et al, 1999; Tuccillo et el., 1999) further complicating the interpretation of water-rock interactions. This mixing of the end products of different biogeochemical reactions can be enhanced by fluctuations in the water table and the small spatial scale at which the reactions occurred.

A surficial aquifer contaminated with leaded gasoline was studied by the USGS to determine the effects of organic contaminant degradation on the ground-water chemistry of a local part of the New Jersey Coastal Plain (Cozzarelli et al., 1999). This study provides a good example of the impact of organic compounds on aquifer geochemistry. At the Galloway research site the microbial degradation of hydrocarbons and organic acids in ground water resulted in changes in the oxidation-reduction potential and overall geochemistry of ground water and alterations in the mineral composition of the aquifer. The geochemical reactions that gave rise to the observed composition of the contaminated ground water were a number of oxidation-reduction reactions mediated by bacteria. Inorganic carbon concentrations and $\mathrm{pH}$ increased in the contaminated water as organic carbon was oxidized to bicarbonate through microbial degradation reactions. Aerobic degradation of dissolved hydrocarbons resulted in the depletion of oxygen. In the absence of oxygen, anaerobic degradation reactions became important. Nitrate, iron, and sulfate reduction were important biogeochemical processes in the shallow ground water at this site. Organic acids, which are intermediates in the degradation of hydrocarbons, accumulated in the contaminated water.

Further detailed geochemical investigations shed light on what controlled the microbial processes in this system and how they varied in time and space. A combination of nitrate and oxygen concentrations and the availability of metabolizable organic carbon were determined to be important controls on nitrate depletion coupled to organic-carbon oxidation. In another vertically narrow zone of the aquifer, Fe (III) reduction and sulfate 
reduction occurred where nitrate and oxygen were depleted. Significant vertical heterogeneities of these constituents reflected the small-scale spatial and temporal heterogeneities in biogeochemical reactions. Temporal variations in geochemical reactions occurred at the Galloway site as well, reflecting the dynamic hydrologic system. Increased availability of electron acceptors was observed during periods of the increased recharge as evidenced by rises in the water table and lowered concentrations of degradable organic compounds in the ground water. High concentrations of hydrocarbon metabolites (organic acids) indicated that enhanced degradation of hydrocarbons occurred under these conditions. The geochemical character of the aquifer at the Galloway site was thus affected by numerous microbially mediated reactions that occured at a small spatial scale as well as by changes in these reactions over time due to mixing with infiltrating water and rising and falling water levels.

Investigations of the aquifer solids were undertaken at the Galloway Site in addition to the aqueous geochemical investigations. Changes in the aquifer solids were a direct consequence of the degradation of the introduced organic compounds. Authigenic iron-containing minerals, siderite, ferroan calcite, and magnetite were identified in shallow aquifers associated with hydrocarbon degradation (Baedecker et al. , 1992). The authigenic minerals were reported in the anoxic zones of shallow aquifers containing high concentrations of dissolved hydrocarbons, ferrous iron, and bicarbonate. The formation of these authigenic minerals was clearly related to the interaction of the reduced end products of the microbial degradation of hydrocarbons, such as ferrous iron and hydrogen sulfide.

The availability of organic carbon did not limit either iron reduction or sulfate reduction; the hydrocarbons present in the anoxic, perched water have been shown to support growth of both iron and sulfate reducers in sediment from this site (Cozzarelli et al., 1999). It was the depletion of microbially reducible solid ironoxyhydroxides, and the coating of iron oxide surfaces with reduced iron phases, in narrow zones in the anoxic aquifer that limited iron reduction and allowed sulfate reduction to occur. The stability of the iron oxides remaining in the aquifer allowed sulfate reduction to become energetically favorable at the expense of iron reduction, as described by Postma and Jakobsen (1996). The mixing of the end products of iron reduction and sulfate reduction in groundwater at the Galloway site, similar to the process observed by Baedecker et al. (1992) resulting in the siderite and magnetite formation, was enhanced by the fluctuations in the water table over time and the small spatial scale at which the reactions appear to be occurring.

The results of the Galloway study underscore the need to determine small-scale geochemical changes so that the biogeochemical processes occurring in organic-rich subsurface environments can be evaluated. The reactions that controlled the distribution of hydrocarbons and organic acids in the shallow aquifer were microbially mediated oxidation-reduction reactions. The concentration gradients observed in contaminated groundwater were complicated by the occurrence of these reactions at a micro-scale. The impacts of hydrologic processes were different in shallow groundwater and the regional aquifer due to the different hydrodynamics of these two regimes. Recharge water entering the perched-water zone is depleted of $\mathrm{O}_{2}$ and $\mathrm{NO}_{3}{ }^{-}$as it mixes with contaminated water in the shallow, higher permeability zone. These electron acceptors did not reach the deeper lower-permeability zone. The chemical effects resulting from the microbial degradation of the hydrocarbons lead to discrete zones where secondary minerals, such as iron sulfide precipitated. Thus, the biogeochemical processes and resulting changes in groundwater and aquifer composition had to be examined differently depending on the local aquifer physical and chemical properties. The heterogeneous distribution of both the hydrocarbon source material and the aqueous and solid phase electron acceptors were important controls on the progress of degradation reactions.

Similarly, the presence of biodegradable organic matter in any potentially recharged ground water or in the aquifer matrix of an Aquifer Storage and Recovery (ASR ) system will result in the consumption of oxygen and other electron acceptors. The resulting changes in oxidation-reduction potential and $\mathrm{pH}$ could have a significant impact on ASR systems. Redox changes can affect solubility and precipitation reactions, which impact both physical aspects of operating ASR systems, such as well clogging, and other aspects such as produced water quality (Pyne, 1995). The mineralization of the organic matter or dissolved organic compounds will also produce $\mathrm{CO}_{2}$. An important product of microbial nitrate reduction is ammonium, which can exchange for other cations on the aquifer solids. If solid phase iron oxides are present in the aquifer iron reduction will occur, resulting in high dissolved iron concentrations in the aquifer. Likewise if sulfate reduction occurs, due to the presence of dissolved sulfate, hydrogen sulfide will be produced and, due to its' low solubility, will likely precipitate as iron sulfide minerals. For other trace metals the solubility in the ASR system may increase with increasing reduction. 
When considering ASR, it is important to keep in mind that many of these processes are reversible and that subsequent withdrawal of the recharged ground water may result in reoxidation of many of the reduced species.

Taking into account the availability and stability of the aquifer solids is very important. Much of the oxidizing or reducing potential of the system will be stored in the aquifer solids and measurement of the dissolved concentrations alone will not give an adequate indication of the potential occurrence of geochemical alterations.

\section{References}

Baedecker, M. J., Back, W., 1979. Modern marine sediments as a natural analog to the chemically stressed environment of a landfill. J. Hydrol. 43, 393-414.

Baedecker, M. J., Cozzarelli, I. M., 1992. The determination and fate of unstable constituents in contaminated ground water. In: Lesage, S., Jackson, R. E. (Eds.), Ground-Water Contamination and Analysis at Hazardous Waste Sites. Marcel Dekker, Inc., New York, pp. 425-462.

Baedecker, M. J., Cozzarelli, I. M., Evans, J. R., Hearn, P. P., 1992. Authigenic mineral formation in aquifers rich in organic material. In: Kharaka, Y. K., Maest, A. S. (Eds.), 7th International Symposium on Water-Rock Interaction, Proc. Balkema, Rotterdam, pp. 257-261.

Baedecker, M.J., Cozzarelli, I.M., Siegel, D.I., Bennett, P.C. and Eganhouse, R.P., 1993, Crude oil in a shallow sand and gravel aquifer: 3. Biogeochemical reactions and mass balance modeling in anoxic ground water: Applied Geochemistry, v. 8, p. 569-586.

Bekins, B.A., Cozzarelli, I.M., Godsy, E.M., Warren, E., Essaid, H.I., and Tuccillo, M.E., 2001, Progression of natural attenuation processes at a crude-oil spill site, II. Controls on spatial distributions of microbial populations, Journal of Contaminant Hydrology, v. 53, p. 387-406.

Chapelle, F. H., Lovley, D. R., 1992. Competitive exclusion of sulfate-reduction by Fe(III)-reducing bacteria: a mechanism for producing discrete zones of high-iron ground water. Ground Water 30, $29-36$.

Cozzarelli, I.M., Herman, J.S., Baedecker, M.J., Fischer, J.M., 1999, Geochemical heterogeneity of a gasolinecontaminated aquifer. Journal of Contaminant Hydrology, v. 40, p. 261-284.

Cozzarelli, I. M., Bekins, B. A., Baedecker, M.J., Aiken, G.R., Eganhouse, R. P., and Tuccillo, M. E., 2001, Progression of Natural Attenuation Processes at a Crude-Oil Spill Site, I.Geochemical Evolution of the Plume, Journal of Contaminant Hydrology, v. 53, p. 369-385.

Lyngkilde, J. and Christensen, T.H., 1992, Redox zones of a landfill leachate pollution plume (Vejen, Denmark). Journal of Contaminant Hydrology, v. 10, p. 273-289.

Postma, D., and Jakobsen, R., 1996, Redox zonation: equilibrium constraints on the Fe (III)/SO4-reduction interface: Geochimica et Cosmochimica Acta, v. 60, p. 3169-3175.

Pyne, R.D., 1995, Groundwater Recharge and Wells: A Guide to Aquifer Storage Recovery. Lewis Publishers, Boca Raton, Florida, 376pp.

Tuccillo, M.E., Cozzarelli, I.M., and Herman, J.S., 1999. Iron reduction in the sediments of a hydrocarboncontaminated aquifer. Applied Geochemistry, 14, no. 5: 71-83. 


\title{
Long Term Fate of Organic Micro-pollutants in the Subsurface Environment, Cape Cod, Massachusetts - From Field Surveys to Experimentation
}

\author{
Larry B. Barber (lbbarber@usgs.gov) \\ U.S. Geological Survey, 3215 Marine Street, Boulder, Colorado 80303
}

\begin{abstract}
Understanding the processes controlling the fate of organic micro-pollutants in the subsurface environment has been the focus of research conducted at the Cape Cod Toxics Substances Hydrology Research Site (Barber, 1988; Barber and others, 1988; Thurman and others, 1986; Harvey and Barber, 1992), as well as other locations around the U.S (Barber and others, 1997; Flynn and Barber, 2000; Leenheer and others, 2001). In particular, this research focuses on the fate of organic contaminants associated with treated municipal wastewater. Although a hierarchical analytical approach is used to characterize both natural and contaminant organic matter (Barber, 1992; Leenheer and others, 2001) particular attention has been given to detergent derived compounds (Thurman and others, 1987; Field and others, 1992a, 1992b; Barber and others, 1995; Krueger and others, 1998a, 1998b). Much of what has been learned from these investigations about subsurface hydrogeochemistry and field experimental protocol also should be applicable to other types of emerging contaminants (Barber and others, 2000; Kolpin and others, 2002) that have not yet been studied in detail.
\end{abstract}

Initial surveys at the Cape Cod site involving installation of monitoring wells and conducting water quality sampling, identified an extensive plume of sewage contaminated groundwater extending more than $5 \mathrm{~km}$ from sand and gravel rapid infiltration beds used for disposal of secondary treated domestic wastewater (LeBlanc, 1984). Subsequent investigations to further characterize the hydrogeological conditions and organic geochemistry of the plume indicated that a variety of trace organic chemicals had persisted for more that thirty years in the subsurface environment (Barber, 1988; Barber and others, 1988).

Investigations at other aquifer recharge sites using different suites of trace organic compounds (Tomson and others, 1981; Bouwer and others, 1984; Leenheer and others, 2001) have typically focused on the removal of compounds during infiltration through the vadose zone. However, few studies have traced the resulting plumes of contamination as the recharged wastewater is incorporated into the groundwater system. Most trace organic contaminants undergo significant degradation in the biologically and chemically active zone known as the "schmutzdecke", and removal rates decrease with increasing depth. Once contaminants have been transported out of the zone of influence from the infiltration site and introduced into uncontaminated portions of the aquifer, additional attenuation in the core of the plume occurs, but at lower rates than in the infiltration zone. The fate of organic contaminants in the subsurface depends on geochemical and nutrient conditions, with low dissolved oxygen/low nutrient conditions favoring long-term persistence.

These findings led to the development of a conceptual model of processes governing the long-term fate of organic contaminants in the Cape Cod aquifer (Field and Barber, 1994). This model consists of biogeochemical reactors in series. Under the aerobic conditions existing in the infiltration basins, biodegradation can effectively attenuate the moderately degradable compounds that are present in the treated effluent. The rapidly degradable component of the dissolved organic matter (DOM) is removed during the wastewater treatment process. During infiltration, additional removal occurs during the first meter of transport through the unsaturated zone due to sorption and biodegradation. However, because of the high organic loading and aerobic biodegradation occurring in this zone, the aquifer beneath the infiltration beds rapidly becomes oxygen depleted, and aerobic processes decrease. The moderately degradable component of the DOM is removed during the initial infiltration, and compounds that persist through this zone are generally more recalcitrant in nature and less susceptible to further aerobic biodegradation. Once these compounds reach the saturated zone of the unconfined aquifer they are transported in the subsurface along the regional groundwater flow path. The saturated zone under the beds can become anoxic, and anaerobic biodegradation of compounds not degraded by aerobic processes (i.e. tetrachloroethene) can occur. The effect of sorption is diminished with distance from the infiltration beds because of the low organic carbon content of the aquifer sediments (Barber, 1994). Organic contaminants that persist through the near bed zones can be transported by the regional groundwater flow system with little additional attenuation because (1) the degradable 
and sorptive components have been removed near the beds, (2) the groundwater in the contaminant plume is anoxic, (3) the water becomes nutrient limited for microbial processes, and the (4) the subsurface microbial community structure changes and is significantly less active. Although this model is based on results from a rapid infiltration wastewater disposal site in a shallow unconfined aquifer, the primary hydrological and biogeochemical processes are similar to, and the understanding can be applied to aquifer recharge and recovery operations.

In addition to steady-state processes associated with the various reactive zones of the rapid infiltration system, there are dynamic factors such as loading rates, wetting/drying cycles, and groundwater hydrology. Within a given infiltration cycle, contaminants can be introduced into the aquifer as a series of pulses. When sediments are loaded after a period of drying, compounds stored in the shallow infiltration zone can be remobilized and released as a concentrated pulse. After this initial flushing, concentrations ambient to the effluent pass into the subsurface during the lag time for microbial activity to establish. Once aerobic biodegradation begins, concentrations of compounds in the effluent can be significantly decreased. This phase of efficient removal proceeds until the reactive zone becomes anoxic due to oxygen consumption resulting from the effluent organic loading, at which point aerobic degradation ceases and compounds present in the effluent again are introduced to the subsurface.

Of course, the groundwater hydrogeology plays a significant role in the subsurface fate and transport of organic micro-pollutants. Factors such as depth to water table, sediment porosity and permeability, and ground water velocity all control how rapidly and to what extent contaminants make their way from the point of recharge to point of recovery.

Because of the widespread use of surfactants in domestic and commercial applications, and their direct introduction into the hydrologic environment through disposal down the drain, they are ubiquitous in treated wastewater effluents throughout the United States. There are a variety of common surfactants in use including nonionic, anionic, and cationic compounds. Research at the Cape Cod site has focused primarily on the anionic surfactant class, alkylbenzene sulfonic acids. Linear alkylbenzene sulfonates (LAS) are the major anionic surfactants currently in use, whereas branched chained alkylbenzene sulfonates (ABS) were in use prior to 1964 after which they were replaced with LAS. Both LAS and ABS consist of a series of homologs with alkyl chain lengths ranging from 10-14 carbons. The ABS compounds have a chemical structure that prevents biological degradation whereas the LAS compounds are rapidly biodegraded under aerobic conditions. This mixture of homologs and positional isomers results in a complex suite of chemical structures, each with differing biodegradation and sorption characteristics, that can be used as intrinsic tracers in experiments to identify environmental processes.

The sewage plume resulting from wastewater recharge at the Cape Cod site consists of three distinct geochemical zones. Pristine freshwater recharge overlies the plume and is very low in dissolved ions and DOM and is fully oxygenated. The transition zone has an increase in specific conductance and DOM, and dissolved oxygen concentrations decrease. The plume core is primarily sewage effluent, has a high specific conductance and DOM, and is anoxic. This geochemical gradient can be used to experimental advantage because each zone has a distinct set of biogeochemical processes.

The Cape Cod site has an extensive three-dimensional sampling array consisting of multilevel sampling devices (MLS) spaced at 1-10 meter intervals aligned perpendicular to and along the regional groundwater flow path (LeBlanc and others, 1991). This array allows in-situ natural gradient experiments to be conducted within the various geochemical zones. Results from a series of pulsed and continuous injection tracer tests using LAS and sodium bromide indicate that: (1) biodegradation rates within the aquifer are low, spatially variable, and controlled primarily by dissolved oxygen content, (2) biodegradation can be self limiting as the LAS and oxygen are consumed, resulting in formation of stable metabolites, (3) under oxygen limited conditions, biodegradation selectively removes the LAS isomers having the longest linear side chains, (4) sorption to the aquifer sediments results in chromatographic separation of the various homologs and isomers that is inversely proportional to the water solubility, even at very low sediment organic carbon contents, (5) sorption to the sediments results in variable transport rates, thus breakthrough of contaminants in the recovery wells will be dynamic.

The impact of the organic component held in sediment storage on long-term water quality considerations is illustrated by observations on the time required for dissolved organic carbon (DOC) concentrations to decrease in monitoring wells near the infiltration beds after the wastewater disposal practices ceased (Barber and Keefe, 1999). After nearly 60 years of continuous disposal, the wastewater source was shut off in December 1995. Monitoring of 
an extensive network of MLS immediately down gradient of the disposal beds indicated that the soluble components of the plume, such as chloride and boron, were rapidly flushed from the system (concentrations returned to baseline conditions in less than 6 months). In contrast, after 6 years the dissolved oxygen and DOC levels have still not returned to baseline conditions.

In summary, depending on the operational controls of aquifer recharge activities, the nature of the recharge water, and the hydrogeology of the receiving aquifer, a variety of trace organic contaminants can be introduced into the groundwater, with little additional attenuation occurring with subsequent transport and recovery. Rates of in situ removal can be difficult to determine, and work at the Cape Cod site has developed methods and protocols to quantitatively determine the mechanisms, rates, and geochemical constraints of subsurface removal processes.

\section{References}

Barber, L.B., II, 1988, Dichlorobenzene in ground water: Evidence for long-term persistence: Ground Water, v. 26, p. 696-702.

Barber, L.B., II, 1992, Hierarchical analytical approach to evaluating the transport and biogeochemical fate of organic compounds in sewage-contaminated ground water, Cape Cod, Massachusetts: Chapter 4 in S. Lesage and R.E. Jackson, eds., Ground water Contamination and Analysis at Hazardous Waste Sites, Mercel Dekker, Inc., New York, p. 73-120.

Barber, L.B., II, 1994, Sorption of chlorobenzenes to Cape Cod aquifer sediments: Environmental Science and Technology, v. 28, p. 890-897.

Barber, L.B., II, Brown, G.K., Kennedy, K.R., Leenheer, J.A., Noyes, T.I., Rostad, C.E., and Thorn, K.A, 1997, Organic contaminants that persist during aquifer storage and recovery of reclaimed water in Los Angeles County, California: American Water Resources Association, Conjunctive use of Water Resources: Aquifer Storage and Recovery, p. 261-272.

Barber, L.B., Brown, G.K., and Zaugg, S.D., 2000, Potential endocrine disrupting organic chemicals in treated municipal wastewater and river water: Chapter 7 in Keith, L.H., Jones-Lepp, T.L., and Needham, L.L. eds., Analysis of Environmental Endocrine Disruptors, American Chemical Society Symposium Series 747, American Chemical Society, Washington, DC, p. 97-123.

Barber, L.B. and Keefe, S.H., 1999, Evolution of a ground-water sewage plume after removal of the 60 -year-long source, Cape Cod, Massachusetts-Changes in the distribution of dissolved oxygen, boron, and organic carbon: U.S. Geological Survey, Water-Resources Investigations Report 99-4018C, p. 261-270.

Barber, L.B., II, Krueger, C., Metge, D.W., Harvey, R.W., and Field, J.A., 1995, Fate of linear-alkylbenzene sulfonate in ground water-Implications for in situ surfactant enhanced remediation: Chapter 8 in D.A. Sabatini, R.C. Knox, and J.H. Harwell, eds., Surfactant-Enhanced Remediation of Subsurface Contamination-Emerging Technologies, American Chemical Society Symposium Series 594, p. 95-111.

Barber, L.B., II, Thurman, E.M., Schroeder, M.P., and LeBlanc, D.R., 1988, Long-term fate of organic micropollutants in sewage-contaminated ground water: Environmental Science and Technology, v. 22, p. 205-211.

Bouwer, E.J., McCarty, P.L., Bouwer, H., and Rice, R.C., 1984, Organic contaminant behavior during rapid infiltration of secondary wastewater at the Phoenix $23^{\text {rd }}$ Avenue project: Water Research, v. 18, p. 463-472.

Field, J.A. and Barber, L.B., 1994, Wastewater treatment and ground water contamination: Chapter 22 in Uri Zoller, ed., Ground Water Contamination and Control, Marcel Dekker, Inc., New York, 377-389.

Field, J.A., Barber, L.B., II, Thurman, E.M., Moore, B.L., Lawrence, D.L., and Peake, D.A., 1992a, Fate of alkylbenzenesulfonates and dialkyltetralinsulfonates in sewage contaminated ground water: Environmental Science and Technology, v. 26, p. 1140-1148. 
Field, J.A., Leenheer, J.A., Thorn, K.A., Barber, L.B., II, Rostad, C., Macalady, D.L., and Daniel, S.R., 1992b, Identification of persistent anionic-surfactant derived chemicals in sewage effluent and ground water: Journal of Contaminant Hydrology, v. 9, p. 55-78.

Flynn, J.L. and Barber, L.B., 2000, Quality of ground-water and surface water in an area of individual sewage disposal system usage near Barker Reservoir, Nederland, Colorado, August-September, 1998: U.S. Geological Survey, Open-File Report 00-214, 8 p.

Harvey, R.W. and Barber, L.B., II, 1992, Associations of free-living bacteria and dissolved organic compounds in a plume of contaminated ground water: Journal of Contaminant Hydrology, v. 9, p. 91-103.

Kolpin, D.W., Furlong, E.T., Meyer, M.T., Thurman, E.M., Zaugg, S.D., Barber, L.B., and Buxton, H.T., 2002, Pharmaceuticals, hormones, and other organic wastewater contaminants in U.S. Streams, 1999-2000: A national reconnaissance: Environmental Science and Technology, v. 36.

Krueger, C.J., Barber, L.B., Metge, D.W., and Field, J.A., 1998a, Fate and transport of linear alkylbenzene sulfonate in a sewage-contaminated aquifer - A comparison of natural-gradient pulsed tracer tests: Environmental Science and Technology, v. 32, p. 1134-1142.

Krueger, C.J., Radakovich, K.M., Sawyer, T.E., Barber, L.B., Smith, R.L., and Field, J.A., 1998b, Biodegradation of the surfactant linear alkylbenzenesulfonate in sewage-contaminated groundwater: A comparison of column experiments and field tracer tests: Environmental Science and Technology, v. 32, p. 3954-3961.

LeBlanc, D.R., 1984, Sewage plume in a sand and gravel aquifer, Cape Cod, Massachusetts: U.S. Geological Survey Water-Supply Paper 2218, 28 p.

LeBlanc, D.R., Garabedian, S.P., Hess, K.M., Gelhar, L.W., Quadri, R.D., Stollenwerk, K.G., and Wood, W.W., 1991, Large-scale natural-gradient tracer test in sand and gravel, Cape Cod, Massachusetts. 1. Experimental design and observed tracer movement: Water Resources Research, v. 27, p. 895-910.

Leenheer, J.A., Rostad, C.E., Barber, L.B., Schroeder, R.A., Anders, R., and Davisson, M.L., 2001, Nature and chlorine reactivity of organic constituents from reclaimed water in groundwater, Los Angeles County, California: Environmental Science and Technology, v. 35, p. 3869-3876.

Tomson, M.B., Dauchy, J., Hutchins, S., Curran, C., Cook, C.J., and Ward, C.H., 1981, Groundwater contamination by trace level organics from a rapid infiltration site: Water Research, v. 15, p. 1109-1116.

Thurman, E.M., Barber, L.B., Jr., and LeBlanc, D.R., 1986, Movement and fate of detergents in ground water: A field study: Journal of Contaminant Hydrology, v. 1, p. 143-161.

Thurman, E.M., Willoughby, T., Barber, L.B., II, and Thorn, K.A., 1987, Determination of alkylbenzene sulfonate surfactants in ground water using macroreticular resins and ${ }^{13} \mathrm{C}$ nuclear magnetic resonance spectroscopy: Analytical Chemistry, v. 59, p. 1798-1802. 


\title{
Geochemical Modeling of an Aquifer Storage Recovery Experiment, Charleston, South Carolina
}

\author{
David L. Parkhurst ${ }^{1}$ (dlpark@usgs.gov) and Matthew D. Petkewich ${ }^{2}$ \\ (mdpetkew@usgs.gov) \\ ${ }^{1}$ U.S. Geological Survey, P.O. Box 25046, MS 413, Denver Federal Center, Lakewood, Colorado 80225 \\ ${ }^{2}$ U.S. Geological Survey, 720 Gracern Road, Columbia, South Carolina, 29210
}

\section{Introduction}

Geochemical modeling tools are well suited for analyzing aquifer storage recovery experiments. The types of modeling available include speciation modeling, solute-transport modeling, mole-balance modeling, batchreaction modeling, and one-, two-, and three-dimensional reactive-transport modeling. These modeling techniques range from relatively simple speciation modeling to complex reactive-transport modeling, with corresponding simple to complex requirements of time, data needs, and computer resources. Geochemical modeling should be part of every aquifer storage recovery project, but the extent of modeling must be appropriate for the scale of the project.

In this report, example calculations of several types of geochemical modeling are applied to an aquifer storage recovery experiment in Charleston, South Carolina. The purpose of the aquifer storage operation is to store potable drinking water in a sand and limestone aquifer underlying the city of Charleston. Application of geochemical modeling approaches have been useful in this study in understanding the induced flow in the aquifer, deducing the important chemical reactions, building hypotheses, and identifying unanswered questions related to full-scale operations.

To date, three pilot injection-storage-recovery experiments have been completed. This report is limited to a preliminary analysis of the flow, solute transport, and chemical reactions in the third experiment, which was undertaken between September 11, 2000 and April 2, 2001. During this period, water was injected at approximately $0.042 \mathrm{~m}^{3} / \mathrm{min}$ (11 gpm) for 43 days, stored for 99 days, and extracted by pumping the injection well at a rate of 0.45 $\mathrm{m}^{3} / \mathrm{min}$ (120 gpm) for 61 days. Water was injected and recovered through well CHN-812 (fig. 1); water samples were taken from observation well CHN-809 throughout the experiment and from well CHN-812 during recovery. Both wells were screened over 70 percent of the 22 -m-thick aquifer.

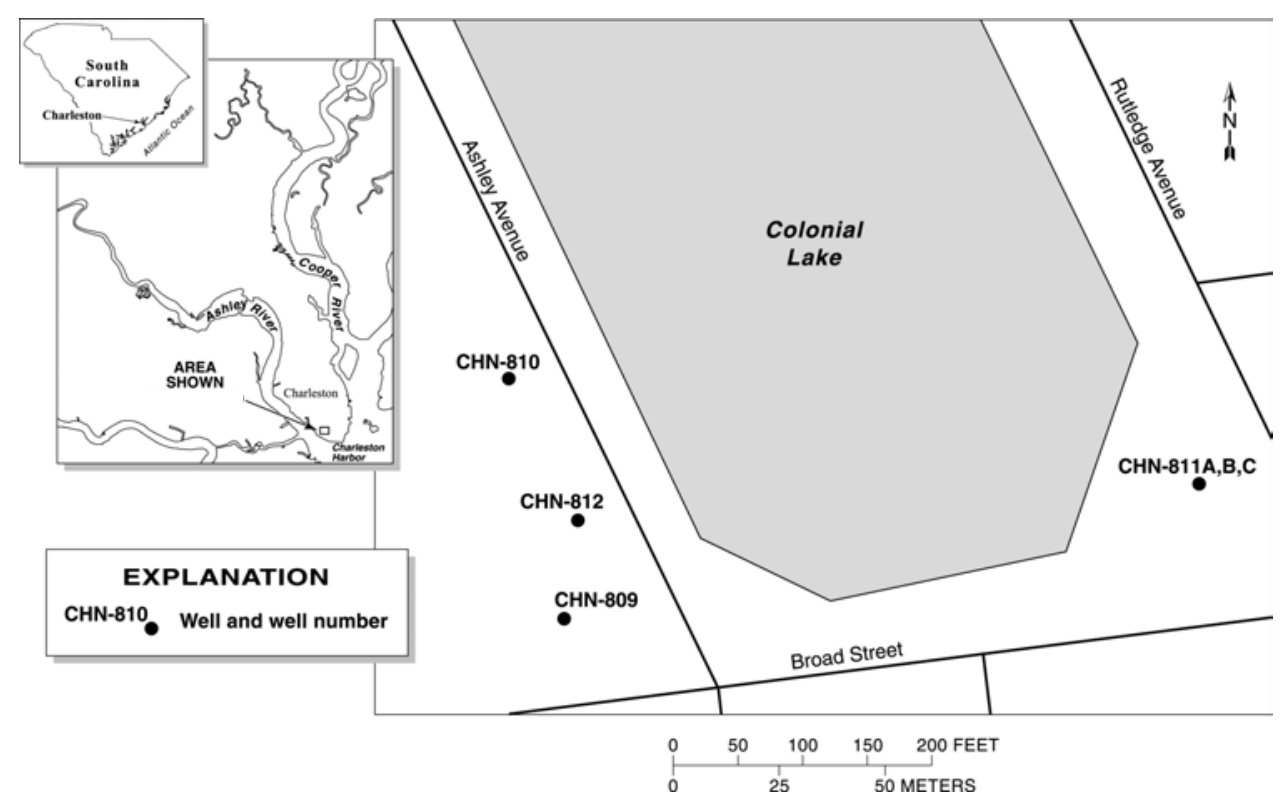

Figure 1.-Aquifer storage recovery site and well locations, Charleston, South Carolina. 


\section{Solute Transport}

Figure 2 shows the chloride concentration at observation well CHN-809 through the injection, storage, and recovery experiment. Given the relatively low injection rate, the rapid breakthrough of low-chloride water at the observation well (approximately $23 \mathrm{~m}$ from the injection well) indicates that the injected water must flow through a small volume of aquifer. If the breakthrough were representative of the entire aquifer, porosity of 2 percent or less would be required, which is not plausible for a predominantly sand aquifer. Alternatively, the flow must occur predominantly through a thin transmissive zone of the aquifer. A limestone layer of 3-m thickness or less occurs near the top of the aquifer. Electrical conductivity logs of observation wells during injection show that this layer has the lowest specific conductance within the aquifer, which indicates that it is the most transmissive zone. It is hypothesized that preferential flow through this layer is the cause of the rapid breakthrough of low-chloride water at the observation well.

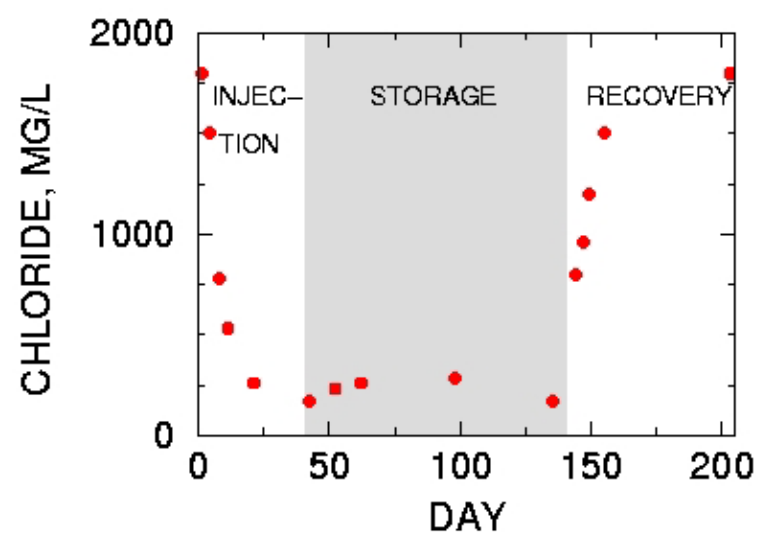

Figure 2.-Chloride concentration in observation well CHN-809 during injection, storage, and recovery; shaded area is period of storage with injection preceding and extraction following this period.
In the breakthrough of low-chloride water, the lowest concentrations of chloride are in the range of 170 to $230 \mathrm{mg} / \mathrm{L}$, in contrast to the injection concentration of approximately $40 \mathrm{mg} / \mathrm{L}$. Thus, it is apparent that although a large proportion of the water is moving through the more hydraulically conductive limestone, some water with large chloride concentration is moving from the rest of the aquifer into the observation well, which causes minimum chloride concentrations to be greater than the injected concentration. A solute-transport model was developed that included a 2-m zone of greater hydraulic conductivity than the rest of the aquifer. By trial and error, it was determined that a horizontal hydraulic conductivity ratio of $120: 1$, for the two model zones of the aquifer, produced concentrations of approximately $200 \mathrm{mg} / \mathrm{L}$ chloride in the observation well following initial breakthrough of low-chloride water. It was assumed that both zones of the aquifer contributed water to the observation well according to the corresponding thickness and hydraulic conductivity.

\section{Geochemical Reactions}

Speciation and inverse modeling were used to deduce chemical reactions that occurred during the experiment. Speciation modeling indicates that calcite should dissolve into the water that is injected into the aquifer.

Mole-balance models were developed for waters from the observation well by assuming the mixing of the injection and background waters. It was determined that mixing plus chemical reaction-dissolution of calcite and cation exchange - could adequately account for the water compositions in the observation well during the experiment. The exchange reaction removes calcium, magnesium, and potassium from solution to the exchanger, and removes sodium from the exchanger to the solution. The combination of removal of calcium and dissolution of calcite is consistent with the high $\mathrm{pH}$ and high alkalinity observed in the observation well after breakthrough of lowchloride water.

One-dimensional reactive-transport modeling with PHREEQC (Parkhurst and Appelo, 1999) was used to test whether equilibrium reactions were consistent with the observations. Whereas inverse modeling showed that calcite and cation-exchange mole transfers could account for the water compositions, mole-balance modeling takes no account of thermodynamic driving forces or kinetics of reactions. The one-dimensional modeling assumed equilibrium for calcite and cation-exchange reactions and used the default exchange constants of the database phreeqc.dat (Parkhurst and Appelo, 1999). The number of exchange sites could not be determined from the available data, except that a minimum number of sites were needed to match the observations; a value of $0.1 \mathrm{eq} / \mathrm{L}$ was assumed. The results of the one-dimensional reactive-transport modeling indicated that equilibrium calcite and 

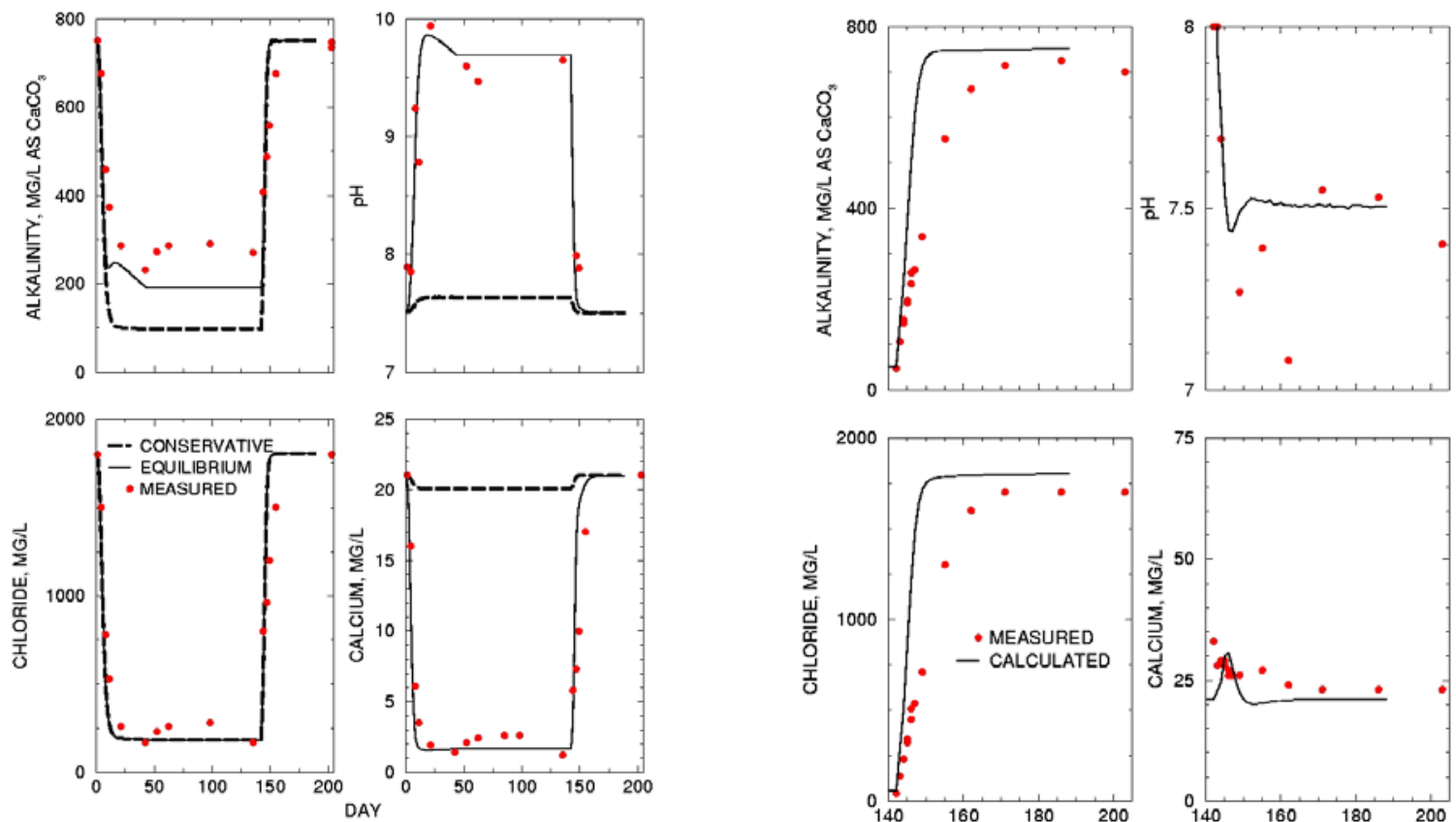

Figure 3.-Observed concentrations in well $\mathrm{CHN}-809$ during injection, storage, and recovery compared to concentrations modeled by assuming equilibrium reactions
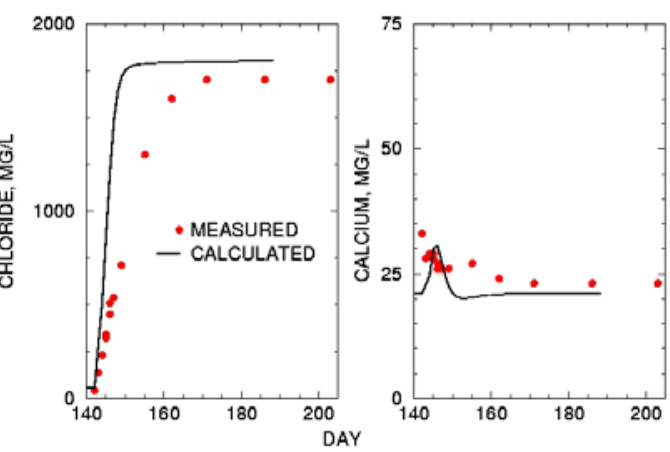

Figure 4.-Observed concentrations in extraction well 810 compared to concentrations modeled by assuming equilibrium reactions. and conservative transport.

cation-exchange reactions - plus mixing of water in the observation well-were consistent with the composition of water from the observation well.

Clays are the most important minerals providing exchange sites, and previous work has shown that clays with significant exchangeable sodium are subject to expansion accompanied by decreased hydraulic conductivity when exchangeable sodium or dilute water is injected (McNeal and Coleman, 1966; Brown and Silvey, 1977). The need for cation exchange to account for chemical compositions and the presence of clays in the aquifer implies that the aquifer may be subject to permeability changes caused by clay expansion. A significant decrease in breakthrough of low-chloride concentrations from the first experiment (approximately 30 days) to the third experiment (approximately 8 days) may be the result of expansion of clay in the less transmissive zone of the aquifer, forcing more water through the limestone zone.

\section{Three-Dimensional Reactive-Transport Model}

A three-dimensional model of the injection, storage, and recovery experiment used the hydraulic properties derived from the solute-transport analysis of chloride and the reactions deduced by speciation, inverse, and onedimensional reactive-transport modeling. The calculations used the simulator PHAST (Parkhurst, and others, 1995, Kipp and Parkhurst, in press). Figure 3 presents the results of the simulations for observation well CHN-809. An additional simulation was run by assuming that only conservative transport occurred, with no calcite or cationexchange reactions. The simulation that included equilibrium reactions more closely matches the alkalinity, calcium, and $\mathrm{pH}$ observations, and, in fact, closely matches the observed concentrations for all major ions. 
Figure 4 compares observed and simulated values for the extraction well during the recovery part of the experiment. The withdrawal of low-chloride water requires less time in the simulation than in the experiment. The difference in recovery duration must result from an inconsistency in the nominal injection and pumping rate, such that the actual recovery appears to produce more low-chloride water than can be accounted for by the injection. However, there is no reason to suspect errors in either the pumping- or injection-rate estimates.

The simulation of the nonconservative constituents for the extraction well was found to be sensitive to the time step used in the numerical modeling. The converging flow at the extraction well generates large velocities (up to $150 \mathrm{~m} / \mathrm{d}$ at the central model cell boundaries) and a sufficiently small time step is needed to obtain an accurate solution. With 5-m model cells, a time step of 0.01 days produced a stable numerical solution during the extraction part of the simulation. With the refined numerical solution, the comparison between calculated and observed concentrations is adequate. However, delayed breakthrough of all constituents is evident, which is related to the discrepancy noted for chloride breakthrough. Equilibrium reactions appear to be applicable, but details may be difficult to match in the dynamic environment of the pumping well. The large velocities may result in incomplete cation-exchange or calcite equilibration, and the appropriate simulation of dispersivity in this environment is not clear.

\section{Conclusions}

The predominant flow in the aquifer storage recovery experiment appears to be in a limestone layer near the top of the aquifer that is approximately $2 \mathrm{~m}$ thick. A hydraulic conductivity ratio of 120:1 for this zone relative to the rest of the aquifer accounts for the timing of the breakthrough of low-chloride water and the minimum chloride concentrations in the observation well, which exceed injection concentrations. By including calcite and cation-exchange equilibrium reactions, results of a three-dimensional reactive transport model are in agreement with the time sequence of major-ion concentrations in the observation and extraction wells. However, several questions can be raised as a result of the geochemical modeling:

1. Why is the modeled extraction of low-chloride water less than that observed?

2. Will water injected in the limestone remain extractable for a long period of time? Or will regional gradients cause the pool of fresh water to migrate?

3. If the water is injected primarily into a thin transmissive zone, will the large surface area of the interfaces between the transmissive layer and adjacent high-chloride layers cause water-quality degradation by leakage across the interfaces?

4. Does injection of low-concentration water affect clay particles and decrease permeability in parts of the aquifer?

\section{References}

Brown, D.L., and Silvey, W.D., 1977, Artificial recharge to a freshwater-sensitive brackish-water sand aquifer, Norfolk, Virginia: U.S. Geological Survey Professional Paper 939, 53 p.

Kipp, K.L., and Parkhurst, D.L., in press, Parallel processing for PHAST-A 3D reactive-transport simulator: XIV International Conference on Computational Methods in Water Resources, Delft, The Netherlands, 2002, Proceedings.

McNeal, B.L., and Coleman, N.T., 1966, Effect of solution composition on soil hydraulic conductivity and effect of solution composition on the swelling of extracted soil clays: Soil Science Society of America Proceedings, Vol. 30, No. 3, pp. 308-317.

Parkhurst, D.L., and Appelo, C.A.J., 1999, User's guide to PHREEQC (Version 2)—A computer program for speciation, batch-reaction, one-dimensional transport, and inverse geochemical calculations: U.S. Geological Survey Water-Resources Investigations Report 99-4259, 312 p.

Parkhurst, D. L., Engesgaard, Peter, and Kipp, K. L., 1995 Coupling the geochemical model PHREEQC with a 3D multi-component solute-transport model: V.M. Goldschmidt Conference, 1995, State College, Pa., Program and Abstracts, pp. 77-78. 


\title{
Transport and Fate of Water-Quality Indicators after $\mathbf{4 0}$ Years of Artificial Recharge with Treated Municipal Wastewater to the Central Ground-Water Basin in Los Angeles County
}

\author{
Roy A. Schroeder (raschroe@usgs.gov) and Robert Anders (randers@usgs.gov) \\ U.S. Geological Survey, 5735 Kearny Villa Road, Suite O, San Diego, California 92123
}

\section{Introduction}

The use of treated municipal wastewater effluent (recycled water) to replenish potable ground-water supplies through artificial recharge is increasing, especially in the arid southwestern United States. Artificially recharging ground water basins is accomplished by delivering large amounts of water, including recycled water, into large holding ponds, or spreading grounds, where the recycled water infiltrates through the unsaturated zone to the water table and moves downgradient to drinking-water aquifers (National Research Council, 1994). In Los Angeles County, the Los Angeles Department of Public Works, using water supplied from the Water Replenishment District of Southern California, has been augmenting the potable ground-water supply in the Central Ground-Water Basin with recycled water for the past four decades. Therefore, this area provides an excellent opportunity to investigate the transport and fate of wastewater constituents as they travel long distances and over long time periods from the point of recharge to points of withdrawal. The U.S. Geological Survey (USGS) has been engaged in such investigations in this area for the past 10 years. Manuscripts and abstracts based on these investigations are listed in chronological order of their publication in the last section of this abstract.

The California Department of Health Services (DOHS) regulates artificial recharge using recycled water under Title 22 of the California Administrative Code. In addition to ensuring compliance with the common drinking-water standards for all constituents, the DOHS also proposed additional regulations for organic carbon, nitrogen, and pathogens. These proposed additional regulations require that no more than $1 \mathrm{mg} / \mathrm{L}$ organic carbon and nitrogen in the ground water be of wastewater origin. As a result, the proportion of recycled water in the total recharge to the area described in this study is limited to 50 percent annually and to 35 percent within three contiguous years. Likewise, protection from exposure to pathogens is achieved by requiring separation between points of recharge and withdrawal that results in a ground-water travel time of at least 6 months (Hultquist and others, 1991).

Artificial recharge at the Montebello Forebay in the Los Angeles area takes place at two spreading grounds (constructed infiltration basins) using an annual delivery of about 150,000 acre-feet of water. One spreading basin is adjacent to the San Gabriel River and includes a short unlined part of the down-stream river channel (see location map). The other is adjacent to the Rio Hondo. Total area of recharge is almost 1,000 acres, and the spreading grounds typically are operated in "wet/dry" cycles wherein each part of the cycle lasts about a week. The recharged water moves from the spreading grounds southward in the direction of regional ground-water flow. The recharge is composed of imported water (from northern California and the Colorado River), recycled water (secondary- and tertiary-treated wastewater from treatment facilities located north of the Montebello Forebay and outside the Central Ground-Water Basin), storm water (local runoff), and a small amount of underflow from the San Gabriel Valley to the north. 
Tertiary treatment includes chlorination-dechlorination and dual-media (charcoal and sand) filtration. Since recycled water was first introduced in 1961, its proportion has gradually increased with time as the proportion of imported water has decreased and now constitutes about 35 percent of annual recharge.

Studies during the last 10 years were conducted in stages, beginning at the spreading grounds and moving farther away from the area of recharge. Water-quality changes occurring over intervals of several days and vertical and horizontal distances of about $25 \mathrm{ft}$ were investigated at a small research basin constructed on the north side of the San Gabriel River spreading grounds in Pico Rivera (see location map). These studies were followed by comprehensive inorganic, isotopic, and organic analyses at production wells near the spreading grounds, and finally by analysis of samples from multilevel monitoring wells as deep as 1,000 ft and located as much as 10 miles from the research basin. Recently, virus tracer studies have begun at the research basin along with laboratory column experiments. Principal findings from these investigations are summarized here.

\section{Research basin}

Study results at the research basin indicate that dissolved organic carbon (DOC) and dissolved nitrogen (present almost entirely as ammonia and nitrate) in percolating recycled water decreased by about one-third and by about 20 to 60 percent, respectively. The decrease in DOC is independent of operating conditions, such as duration of recharge and length of the subsequent desiccation cycle; however, the decrease in dissolved nitrogen concentration does depend on operating conditions to the extent that they influence the establishment of local anoxic conditions in the subsurface. In the subsurface, reduced nitrogen in the form of ammonium and organic nitrogen in recycled water initially is rapidly oxidized to nitrate as oxygen is incorporated with recharge, but the nitrate is partly removed through denitrification that ensues as the subsurface becomes increasingly reducing after several days. Denitrification is confirmed by enrichment in ${ }^{15} \mathrm{~N}$ in the residual nitrate.

\section{Production wells}

A wide variety of inorganic, organic, and isotopic constituents were analyzed in 23 production wells located within $500 \mathrm{ft}$ of the spreading grounds to ascertain which constituents of wastewater origin could be identified and used as tracers to determine percent of recycled water. The production wells range in depth from 250 to $900 \mathrm{ft}$, are screened over intervals ranging from 100 to $400 \mathrm{ft}$ below land surface, and were yielding 500 to 3,000 gallons/min at the time of sampling. Spearman Rank Order correlation coefficients and level of significance were calculated for about 40 water-quality indicators and several physical features such as well depth and distance from spreading grounds to the production wells. About half of the correlations are significant at $\alpha<0.01$, and several are even significant at $\alpha<0.001$. The DOHS would like to base regulations on the percentage of wastewater present in a well by using internal tracers; therefore, an attempt was made to calculate values based on a two-member mixing model. One end member is the recycled water itself and the other is either a background well known to be from 
outside the area containing recycled water or the production well with the lowest measured concentration of each constituent. No completely satisfactory tracer was identified although chloride, boron, ultraviolet absorbance at 254 nanometers, and excitation-emission fluorescence seemed to yield the most reasonable estimates. The large number of statistically significant nonparametric correlations results from the fact that the wastewater signal is preserved in the production wells. However, the failure of parametric calculations to yield precise estimates of the wastewater percentage is caused by the fact that the wells draw water from various depths and ages (with variable extent of degradation) that are not accurately represented by a simple two-member mixture.

\section{Multilevel monitoring wells}

Five multilevel monitoring well sites along a section line $\mathrm{A}-\mathrm{A}^{\prime}$ (see location map) extending from upgradient from the spreading grounds to about 10 miles downgradient were analyzed for wastewater (and other) constituents and to ascertain the long-term effects that artificial recharge has on the ground-water basin. The southernmost site along $\mathrm{A}-\mathrm{A}^{\prime}$ serves as a background insofar as absence of tritium confirms that the ground water at this site is older than 1950 s recharge and, therefore, is still ahead of the advancing wastewater front. Individual organic constituents present in recycled water and in the 23 nearby production wells described earlier, such as ethylenediaminetetraacetic acid (EDTA), are not in ground water that was more than 20 years old (on the basis of tritium/helium-3 dating). The partly degraded sulfonates present in detergents were the only organic chemicals of recycled-water origin that were detected, and they appear to comprise a substantial portion of the DOC present in the groundwater samples containing recycled water. They also contribute to the finding that THM (trihalomethane) formation potentials are less than for ground-water samples containing only natural organic matter. An additional desirable effect of recharging using recycled water here seems to be a slight increase in the redox state of this generally suboxic (less than $1 \mathrm{mg} / \mathrm{L}$ dissolved oxygen) basin insofar as methane is absent where age dating and chemical analyses indicate recycled water is present, whereas methane is present at distances and depths where recycled water has not yet penetrated. Chlorofluorocarbon (CFC) data suggest that older recycled water may have contained more volatile organic contaminants than today insofar as CFC concentrations in ground-water samples older than about 20 years are enriched by as much as 100 -fold over equilibrium with the historical atmospheric level-in contrast to current samples of recycled water, which are only slightly enriched in CFCs.

\section{Virus transport and attenuation}

Recent experiments in which recycled water delivered to the research basin has been amended (seeded) with high concentrations of the bacteriophages PRD-1 and MS2 have been completed to determine the potential for virus transport and attenuation in the subsurface. Extrapolation from results obtained over short distances indicates that 7-log removal, an amount required by the DOHS for human enteric viruses, occurs for these surrogates over a distance of about $100 \mathrm{ft}$ in the Montebello Forebay. 


\section{USGS publications on SAT studies in Los Angeles County}

Schroeder, R.A., and Anders, Robert, 1996, Transport and attenuation of wastewater constituents during recharge at a research basin in Los Angeles County: American Geophysical Union Fall Meeting, San Francisco, December 15-19, 1996, EOS Transactions supplement, v. 77, no. 46, Abstract no. H42F-2, p. F281.

Barber, L.B., II., Brown, G.K., Kennedy, K.R., Leenheer, J.A., Noyes, T.I., Rostad, C.E., and Thorn, K.A., 1997, Organic constituents that persist during aquifer storage and recovery of reclaimed water in Los Angeles County, California, in Kendall, D.W., ed., Proceedings of the AWRA Symposium, Conjunctive Use of Water Resources: Aquifer Storage and Recovery, American Water Resources Association 33rd National Meeting, Long Beach, California, October 19-23, 1997: American Water Resources Association, Herndon, Virginia, TPS-97-2, p. 261-272.

Schroeder, R.A., Anders, Robert, Böhlke, J.K., Michel, R.L., and Metge, D.W., 1997, Water quality at production wells near artificial-recharge basins in Montebello Forebay, Los Angeles County, in Kendall, D.W., ed., Proceedings of the AWRA Symposium, Conjunctive Use of Water Resources: Aquifer Storage and Recovery, American Water Resources Association 33rd National Meeting, Long Beach, California, October 19-23, 1997: American Water Resources Association, Herndon, Virginia, TPS-97-2, p. 273-284.

Anders, Robert, and Schroeder, R.A., 1997, Water-quality changes during recharge with recycled water at a research basin in the Montebello Forebay, Los Angeles County, California, in Kendall, D.W., ed., Proceedings of the AWRA Symposium, Conjunctive Use of Water Resources: Aquifer Storage and Recovery, American Water Resources Association 33rd National Meeting, Long Beach, California, October 19-23, 1997: American Water Resources Association, Herndon, Virginia, TPS-97-2, p. 285-296.

Anders, Robert, and Schroeder, R.A., 1998, Correlations between various water-quality indicators of recharged recycled water in production wells in Los Angeles County: American Geophysical Union Spring Meeting, Boston, May 26-29, 1998, EOS Transactions supplement, v. 79, no. 17, Abstract no. H51B-23, p. S141.

Anders, Robert, Yanko, W.A., Schroeder, R.A., and Jackson, J.L., 1999, Attenuation of PRD-1 and MS-2 during recharge at a constructed research basin in Los Angeles County: $4^{\text {th }}$ International Symposium on Subsurface Microbiology, Vail, Colorado, August 22-27, 1999, Programs and abstracts, p. 28.

Anders, Robert, Yanko, W.A, Schroeder, R.A., and Jackson, J.L., 2000, Attenuation rates for PRD-1 and MS2 during recharge with recycled water at a research basin in Los Angeles County: American Geophysical Union Spring Meeting, Washington, D.C., May 30-June 3, 2000, EOS Transactions supplement, v. 81, no. 19, Abstract no. H41C-04, p. S226-S227.

Leenheer, J.A., Rostad, C.E., Barber, L.B., Schroeder, R.A., Anders, Robert, and Davisson, M.L., 2001, Nature and chlorine reactivity of organic constituents from reclaimed water in groundwater, Los Angeles, County, California: Environmental Science \& Technology, v. 35, p. 3869-3876.

Anders, Robert, and Schroeder, R.A., 2001, Using environmental tracers to determine long-term effects of recharging recycled water in the Central Ground Water Basin, Los Angeles County, California: American Geophysical Union Fall Meeting, San Francisco, December 10-14, 2001, EOS Transactions supplement, v. 82, no. 47, Abstract no. H51C-0338, p. F492.

\section{Acknowledgments}

This investigation was funded under the USGS cooperative program with the Water Replenishment District of Southern California and the County Sanitation Districts of Los Angeles County. We thank numerous individuals from the USGS National Research Program for providing analyses of various chemical constituents and isotopes. 


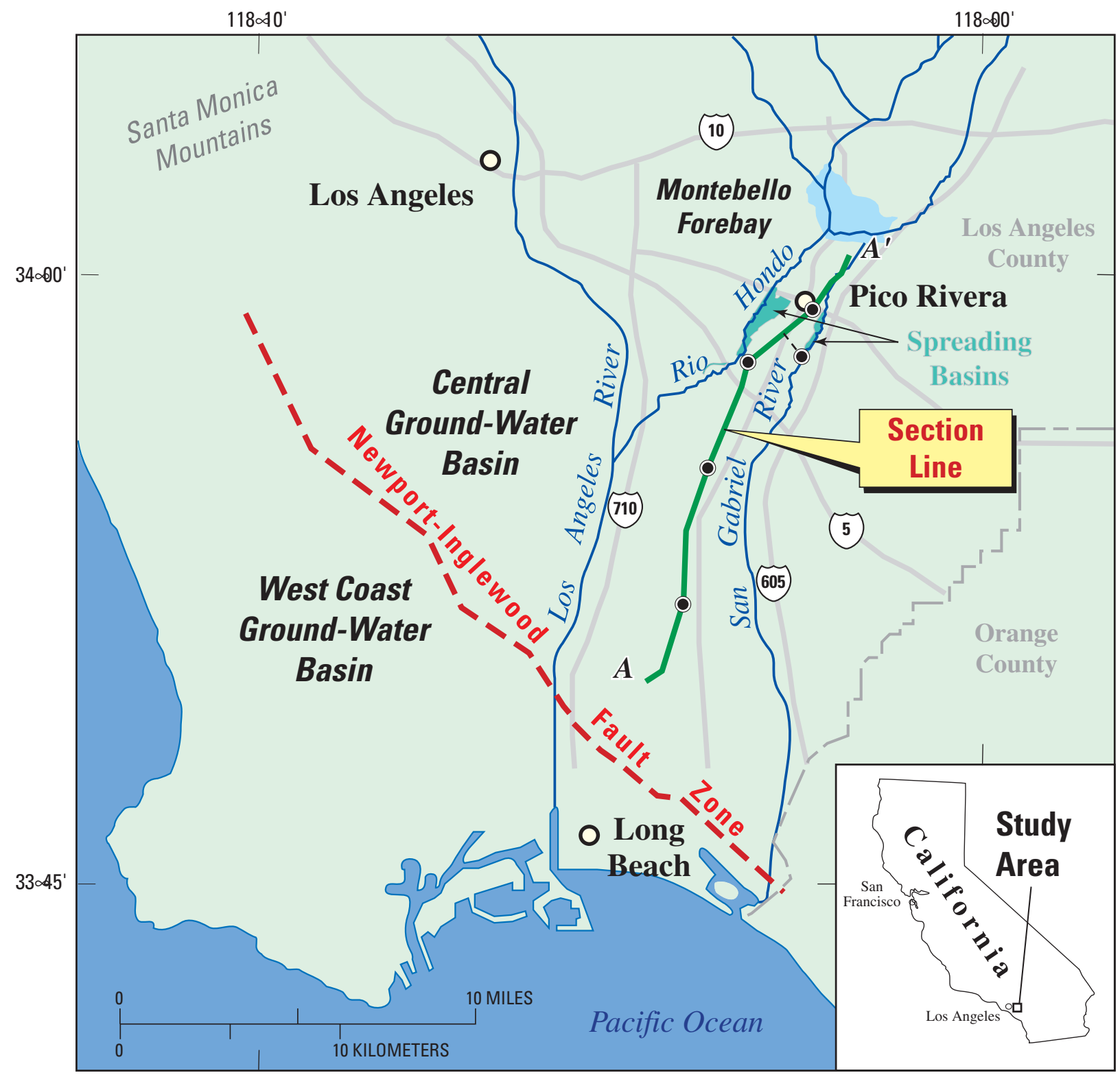

\section{Location map}

\section{References cited}

Hultquist, R.H., Sakaji, R.H., and Asano, T., 1991, Proposed California regulations for ground water recharge with reclaimed municipal wastewater, in Proceedings of the 1991 Specialty Conference, Environmental Engineering, Reno, Nevada: American Society of Civil Engineers, p. 759-764.

National Research Council, 1994, Ground Water Recharge using Waters of Impaired Quality: Washington, D.C., National Academy Press, 182 p. 


\title{
Mobilization of arsenic and other trace elements during aquifer storage and recovery, southwest Florida
}

\author{
Jonathan D. Arthur ${ }^{1}$ (jonathan.arthur@dep.state.fl.us) \\ Adel A. Dabous ${ }^{1}$ (adel.dabous@dep.state.fl.us) \\ James B. Cowart ${ }^{2}$ (cowart@gly.fsu.edu) \\ ${ }_{1}^{1}$ Florida Department of Environmental Protection - Florida Geological Survey, Tallahassee, Florida \\ ${ }^{2}$ Department of Geological Sciences, Florida State University, Tallahassee, Florida
}

\section{Background}

Aquifer storage and recovery (ASR) is an effective method of injecting treated or reclaimed water into confined, or semi-confined permeable formations for later withdrawal as needed. This technology is rapidly becoming widely accepted to address water supply shortages. In 1998, only six ASR facilities were in operation in Florida. As of January 2002, 26 ASR facilities exist in Florida and 19 are permitted for construction. More than 100 ASR facilities are in operation worldwide. ASR not only helps meet increasing demands for drinking water, but it has several other applications in industry, agriculture and environmental restoration. A prime example of the latter application is the role of ASR in the Comprehensive Everglades Restoration Project. Approximately 300 ASR wells are proposed in South Florida to capture $\sim 1.7$ billion gallons per day and store the water in the Floridan aquifer system (FAS) until it is needed.

Early operational testing of ASR wells in Florida (early 1980's to mid 1990's) focused primarily on engineering aspects to address what was considered the bottom line: what percentage of water can be recovered once it has been injected into aquifer storage zones? Although water quality monitoring accompanied the testing of these wells, little attention was paid to water-rock interactions that may occur during ASR operation, unless those processes affected the ability to store or recover water (e.g., precipitation/plugging).

In 1995, leaching experiments conducted by Florida Geological Survey (FGS) staff demonstrated that not only does uranium occur in appreciable amounts ( $>25 \mathrm{ppm})$ within FAS limestones, but also more than $30 \%$ of the uranium can be leached from the rocks under oxidizing conditions in the laboratory. This is especially significant relative to ASR in Florida where the storage zone is the reduced FAS. Source (i.e., surface) waters for ASR contain more dissolved oxygen (DO) than native ground water. Once these waters are introduced into a reduced aquifer, selective leaching and/or mineral dissolution may release metals into the injected water. Recognizing the implications of this research, the Florida Department of Environmental Protection (FDEP) funded the Aquifer Storage and Recovery Geochemistry project, which is now in its fifth year at the FGS. Goals of this project include:

- Investigate water-rock interaction processes that occur during ASR

- Identify the source and mechanism for mobility of trace metals released into injected waters during ASR in varying hydrogeologic settings (e.g., microanalysis and sequential extraction [leaching] experiments)

- Evaluate the effect of repeated ASR cycle testing and other ASR practices (e.g., borehole acidization) on water quality

- Explore the application of $U$ isotopes to identify source waters (injected, native and interstitial) and mixing

- Characterize the chemistry and mineralogy of FAS carbonates

- Provide the FDEP with scientific knowledge on which to base permitting decisions.

Currently, three ASR facilities comprise the focus of our research: NW Hillsborough County Reclaimed water ASR, Rome Avenue ASR (Hillsborough County), and the Punta Gorda ASR facility (Charlotte County). Results of research on the latter two sites, located more than $120 \mathrm{~km}$ apart, are summarized herein.

\section{Mobile metals}

Water quality changes during twelve ASR cycle tests have been evaluated to date. Time-series graphs allow comparison of water chemistry changes during injection, storage and recovery. These graphs also clearly define mixing and mobilization, depending on the initial concentrations of "end member" waters. For example, where concentration of an element is low in injected water, and high in native water (Figure 1), or vice versa, a mixing curve between injected and native ground water is well defined during withdrawal. On the other hand, when the concentration of a metal is low in both injected and native water, but an increase in concentration is observed 
during recovery, mobilization from the aquifer matrix is indicated. Mobilization of As during recovery at the Punta Gorda ASR facility is evident in Figure 1. This pattern is also observed in the ASR well cluster at Rome Avenue.

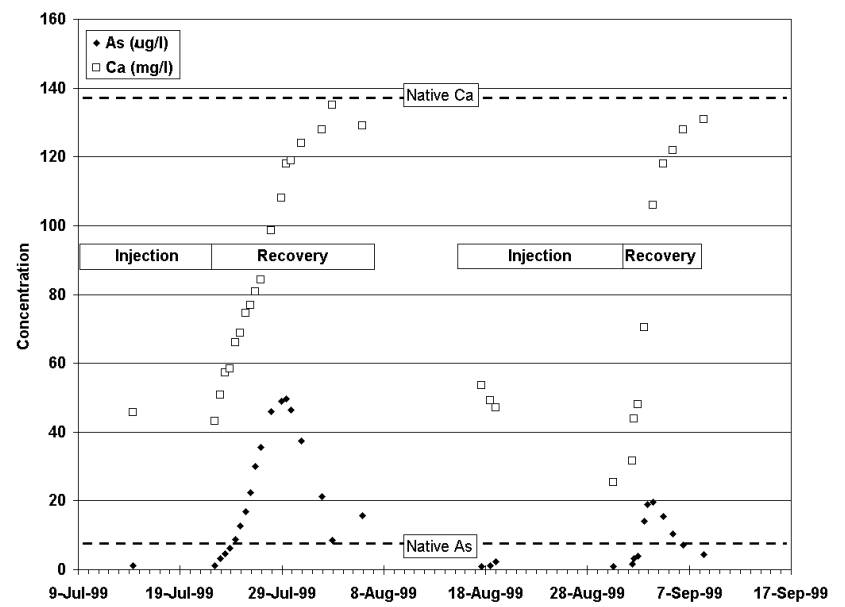

Figure 1. Punta Gorda cycle tests: As and $\mathrm{Ca}$ distributions. During recovery, mixing of low-Ca injected waters and higher-Ca native ground water is observed. Arsenic concentrations in recharge and native ground waters are less than $10 \mu \mathrm{g} / \mathrm{l}$. An As peak (up to $50 \mu \mathrm{g} / \mathrm{l})$ is observed indicating water-rock interaction.
Combined results from cycle tests (Williams and others, 2001; Arthur and others, 2001; unpublished FGS data) suggest that As, Fe, Mn, $\mathrm{Ni}(?), \mathrm{V}($ ?) and $\mathrm{U}$ are mobilized from the aquifer system matrix into the injected waters. Arsenic and $\mathrm{U}$ mobilization are the most consistent and welldocumented trends observed, with concentrations exceeding $85 \mu \mathrm{g} / \mathrm{l}$ and $6 \mu \mathrm{g} / \mathrm{l}$, respectively. Most cycle test results are based on water quality during recovery from ASR wells (e.g., Figure 1), however where ASR monitor wells exist, mobilization is observed during injection as injected water moves past storage zone monitor wells. Preliminary results indicate that these mobilization reactions take place on the order of days, perhaps hours. Three pairs of cycle tests indicate that maximum observed As concentrations decrease during successive cycle testing, however, this preliminary observation holds true only where both cycle test injection volumes are similar and exposure of "new" aquifer matrix to the injected water is minimal. This result is not only desired, but expected assuming that the As source is a fixed concentration within the aquifer matrix and it

is not replenished through mobilization/precipitation from yet unidentified source waters. In cases involving paired cycle tests where the second injection is a larger volume (thus more exposure to previously unexposed aquifer matrix), the maximum As concentration is greater during the second cycle test of the pair (data not shown).

Figure 2 summarizes As concentrations from nine cycle tests with respect to the volume percent of injected water that has been recovered during each test. Input volumes range from 3.7 to 159 million gallons. Some cycles recovered only $75 \%$ while others recovered more than $200 \%$ by volume. There is no apparent relation between the maximum As concentrations and the volume of water recharged/injected during the cycle test (data not shown). On the other hand, Figure 2 suggests that maximum As concentrations are not observed until between $50 \%$ and more than $100 \%$ of the input volume is recovered. This preliminary finding is important to consider in the design and monitoring of cycle tests.

Different geochemical processes or reactions likely govern $\mathrm{U}$ versus $\mathrm{As}$ and $\mathrm{Ni}$ concentrations as indicated by ASR well data from Rome Avenue (Figure 3). The $\mathrm{U}$ concentrations peak earlier than those of $\mathrm{As}$ and $\mathrm{Ni}$, an observation corroborated by data reported in earlier cycle tests results (Arthur and others, 2001) from the Punta Gorda ASR well. This not only suggests different geochemical reactions/processes, but also a possible association of As and Ni mobilization.

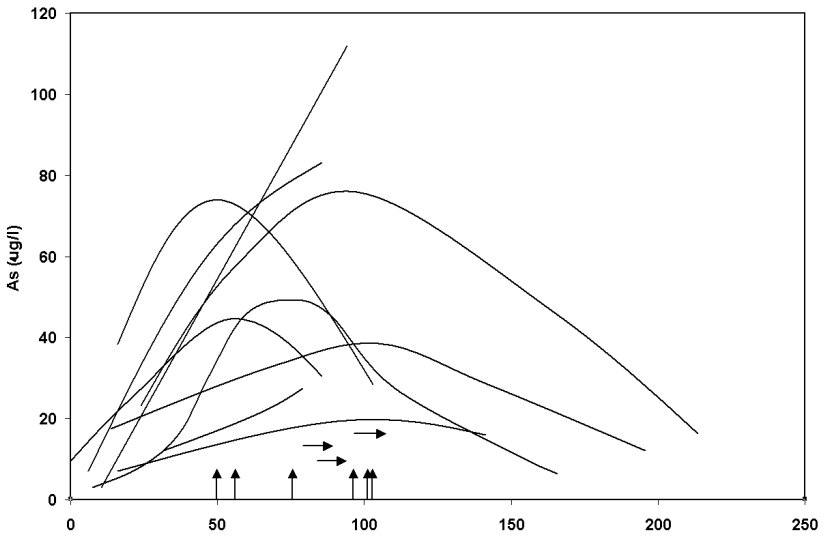

Figure 2. Arsenic concentrations represented by trend lines versus cumulative percent recovery (by volume) of water injected during cycle tests. Vertical arrows indicate estimated maximum As concentration. Horizontal arrows indicate the point beyond which the maximum As concentration would be encountered (i.e., maximum As concentration was not attained before sampling ended). 


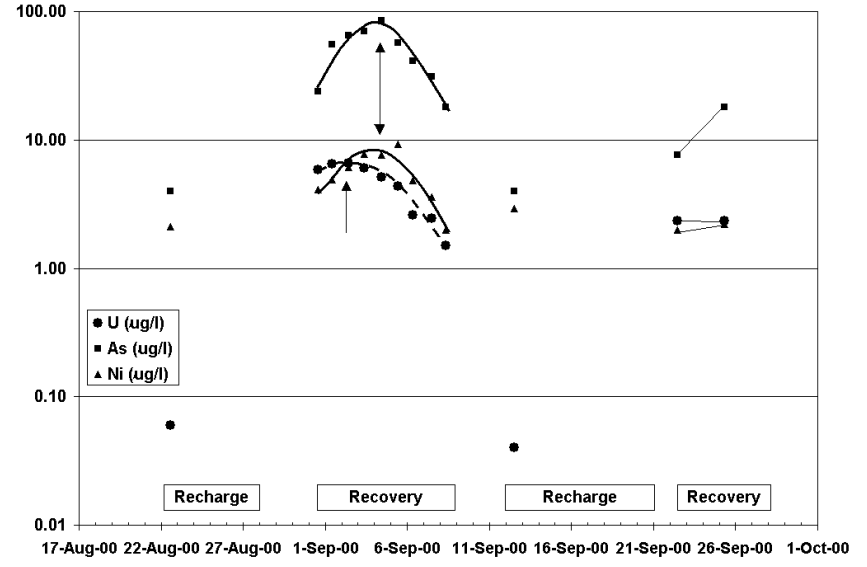

Figure 3. Log-distribution of $\mathrm{As}, \mathrm{Ni}$ and $\mathrm{U}$ concentrations during Rome Avenue cycle tests.
In addition to $\mathrm{U}$ being useful to demonstrate metals mobilization during ASR activities, the activity ratio (AR) of ${ }^{234} \mathrm{U} /{ }^{238} \mathrm{U}$ is also useful for identifying mixing and evolution of waters during ASR in a single well (Arthur and others, 2001). Moreover, AR is useful to demonstrate heterogeneity that exists among wells in a single wellfield (Rome Avenue) or between ASR facilities located kilometers apart (Rome Avenue and Punta Gorda). Various models are proposed to account for the observed trends in AR (Cowart and others, 1998; Arthur and others, 2001; Williams and others, 2001), including selective leaching of ${ }^{234} \mathrm{U}$ from thin U-rich grain carbonate coatings, and selective leaching of ${ }^{234} \mathrm{U}$ from homogeneously distributed $\mathrm{U}$ within grains, coupled with flowing or non-flowing, aggressive, oxic interstitial water.

The aquifer system matrix

Mineralogical and chemical characterization of the FAS storage zone (Oligocene Suwannee Limestone) at both ASR facilities has been determined through a variety of methods. Mineralogy was determined through binocular description, petrography, x-ray diffraction, scanning electron microscopy and energy dispersive x-ray microprobe analyses. Thirty-six samples have been analyzed for 64 elements using multi-method analytical techniques (XRAL and Actlabs laboratories). Results of chemical analyses for 15 samples are reviewed in Arthur and others, (2001). When compared to global averages for limestones, most FAS average compositions are similar, except for perhaps $\mathrm{Cr}$, which is higher in the FAS rocks. However, the maximum concentrations of selected metals (e.g., As, Hg, Ni, U) far exceed global averages (Table 1).
Table 1. Whole rock chemistry, FAS carbonates.

Selected metals concentrations $(n=36)$ :

$\begin{array}{lcccc}\text { Element } & \min & \max & \text { avg. } & \text { global avg. } \\ \mathrm{Fe}_{2} \mathrm{O}_{3} \text { (wt.\%) } & .04 & .39 & .15 & .11 \\ \mathrm{MgO} \text { (wt.\%) } & 0.6 & 19 & 1.74 & 2.20 \\ \mathrm{MnO} \text { (wt.\%) } & \text { bd } & .02 & .02 & .01 \\ \mathrm{~K}_{2} \mathrm{O} \text { (wt.\%) } & .02 & 0.2 & .04 & .04 \\ \mathrm{As} \text { (ppm) } & \text { bd } & 11 & 3 & 2.5 \\ \mathrm{Cr}(\mathrm{ppm}) & \text { bd } & 53 & 17 & 10 \\ \mathrm{Hg}(\mathrm{ppb}) & \text { bd } & 158 & 42 & 30 \\ \mathrm{~S}(\text { wt. \%) } & \text { bd } & 0.1 & .08 & .06 \\ \mathrm{Ni}(\mathrm{ppm}) & \text { bd } & 19 & 4 & 12 \\ \mathrm{U}(\text { ppm) } & \text { bd } & 28 & 5 & 2 \\ & & & & \\ \text { bd - below detection } & & & & \\ \end{array}$

Mineralogy of the ASR storage zone carbonates is dominantly calcite and dolomite with minor clay minerals and organic material, and trace amounts of quartz, gypsum, and pyrite. Pyrite is euhedral to subhedral,

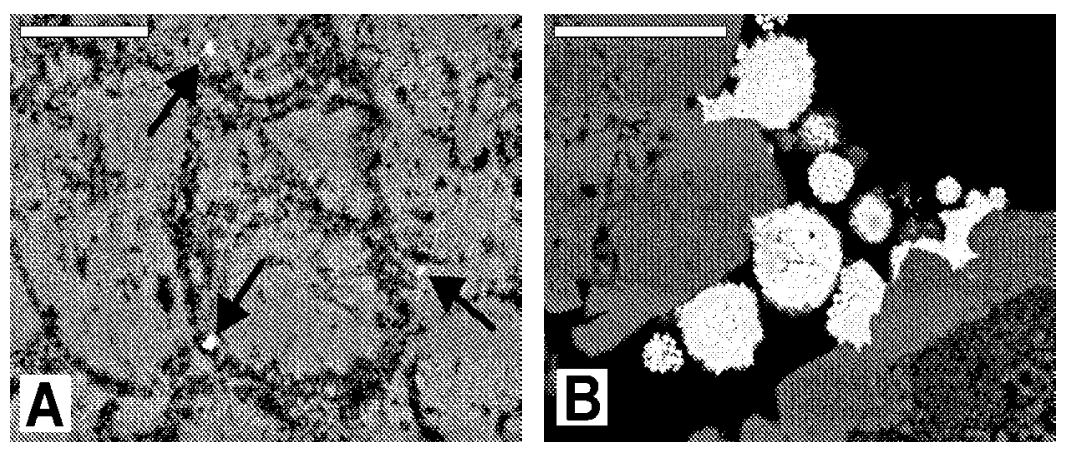

Figure 4. Backscatter electron images of Suwannee Limestone, Floridan aquifer system. White areas are pyrite occuring as: A - finely disseminated intergranular and intragranular subhedral crystals (Rome Avenue, ASR 3, 255 feet below land surface), and B - framboidal masses along pore spaces within carbonate matrix (Rome Avenue, ASR 5, 251 feet below land surface). Scale bar $=10 \mu \mathrm{m}$. averages less than one micron in size, and is intergranular and intragranular with respect to the calcite grains (Figure 4A). Framboidal pyrite masses are also observed (Figure 4B). Semiquantative microprobe analyses of more than 15 pyrite grains tentatively suggests that As concentrations range from less than five weight percent to below detection $(\sim$ two weight percent). Preliminary results of electron microscopy analyses (dot mapping and backscatter imaging) did not reveal other occurrences of detectable As-bearing minerals or mineral coatings. 


\section{Arsenic mobilization mechanisms}

Welch and others (2000) present a comprehensive overview of As hydrogeochemistry. Relative to the FAS, examples of natural As mobilization mechanisms and associated mineral phases include: 1) oxidation of sulfide minerals such as pyrite, which may contain trace elements as lattice substitutes, impurities or in solid solution ( $\mathrm{Ni}, \mathrm{Co}, \mathrm{Cu}, \mathrm{Pb}, \mathrm{As}, \mathrm{Zn}$, and $\mathrm{Mn}$ ), 2) desorption or dissolution of $\mathrm{Fe}$ and $\mathrm{Mn}$ hydroxides (including grain or fracture coatings), 3) oxidation-reduction of organic material, which can mobilize organically complexed As, and 4) biological transformations (see Arthur and others, 2001 for more detail and references).

In addition to our recent work, other studies document As mobility during artificial recharge of aquifers (Stuyfzand, 1998; Ruiter and Stuyfzand, 1998, Brun and others, 1998). In a study of 11 deep well recharge experiments, oxidation of pyrite is reported, resulting in mobilization of As, Co, and Ni (Stuyfzand, 1998). Stuyfzand found that As remains relatively mobile while $\mathrm{Ni}$ and $\mathrm{Co}$ are less mobile and likely co-precipitate or adsorb on to Fe-hydroxides further away from the injection well.

\section{Conclusions}

Aquifer storage and recovery is a viable alternative water supply, but consideration of water-rock interaction is an important water quality and thus human health consideration. The Floridan aquifer system matrix is chemically heterogeneous, which is not only exemplified by carbonate geochemical data, but by the variable geochemical response observed in cycle tests from wells only a few hundred meters apart (Rome Avenue ASR wells). In the ground water, mobilization of $\mathrm{As}, \mathrm{Fe}, \mathrm{Mn}, \mathrm{U}$ and other metals are observed during ASR activities. Variables affecting this mobility include: 1) native and input water chemistry $(\Delta \mathrm{DO}, \mathrm{pH}), 2)$ aquifer matrix chemistry/mineralogy, 3) input water - matrix contact time and number of cycle tests, and 4) site-specific hydrogeology/geochemistry. In addition to $U$ being mobile, $U$ activity ratios are useful toward understanding ground water evolution during ASR activities. Due to concerns regarding maximum contaminant levels, the design, construction and operation of ASR facilities, including monitor well placement and monitoring schedules should take into account the possibility of water-rock interaction and mobilization of metals into recovered waters.

\section{References}

Arthur, J.D., Cowart, J.B. and Dabous, A.A., 2001, Florida aquifer storage and recovery geochemical study: Year three progress report: Florida Geological Survey Open File Report 83, 46 p.

Brun, A., Christensen, F.D., Christiansen, J.S., Stuyfzand, P.J., and Timmer, H., 1998, Water quality modeling at the Langerak deep-well recharge site: in Peters, J.H., et al., eds., Artificial Recharge of Groundwater:

Rotterdam, Netherlands, A.A. Balkema, 474 p.

Cowart, J.B., Williams, H.K., and Arthur, J.D., 1998, Mobilization of U isotopes by the introduction of surface waters into a carbonate aquifer: Geological Society of America Abstracts with Programs, v. 30, no. 7, p. A86.

Ruiter, H. and Stuyfzand, P.J., 1998, An experiment on well recharge of oxic water into an anoxic aquifer: in Peters, J.H., et al., eds., Artificial Recharge of Groundwater: Rotterdam, Netherlands, A.A. Balkema, 474 p.

Stuyfzand, P.J., 1998, Quality changes upon injection into anoxic aquifers in the Netherlands: Evaluation of 11 experiments, in Peters, J.H., et al., eds., Artificial Recharge of Groundwater: Rotterdam, Netherlands, A.A. Balkema, $474 \mathrm{p}$.

Welch, A.H., Westjohn, D.B., Helsel, D.R., and Wanty, R.B., 2000, Arsenic in ground water of the United States: Occurrence and geochemistry: Ground Water, vol. 38, no. 4, p. 589-604.

Williams, H., Cowart, J.B. and Arthur, J.D., 2002, Florida aquifer storage and recovery (ASR) geochemical project: Year One and Year Two Progress Report Submitted to Bureau of Water Facilities Regulation, Florida Department of Environmental Protection, January, 1999, Florida Geological Survey Report of Investigation $100,131 \mathrm{p}$. 


\title{
Using chemical and isotopic tracers to assess hydrogeologic processes and properties in aquifers intended for injection and recovery of imported water
}

\author{
John Izbicki (jaizbick@usgs.gov) \\ U.S. Geological Survey, 5735 Kearny Villa Road, Suite O, San Diego, California 92123
}

\begin{abstract}
During the late 1800's and early 1900's, aquifers underlying the East Bay Plain on the densely populated eastern shore of San Francisco Bay, California (fig. 1), were pumped for water supply. Since that time, pumping has decreased as a result of the availability of imported water from the Sierra Nevada. Injection and recovery of imported water has been proposed by the East Bay Municipal Utilities District (MUD) for aquifers 500 to 650 feet beneath the East Bay Plain (CH2M-Hill, Inc., 2000; Fugro West, 1998, 1999). However, successful injection and recovery of imported water requires a thorough understanding of hydrologic processes within these aquifers including understanding ef recharge processes, sources of high-chloride water to wells, and isolation of deep aquifers from surface sources of contamination. Further, concern regarding flow of water from shallow to deeper aquifers has increased because of the large number of abandoned wells that may serve as conduits for contamination from the upper aquifer to the lower aquifer (San Francisco Bay Regional Water Quality Control Board, 1999). During this study, chemical and isotopic data, in conjunction with test-drilling and hydrogeologic data collected by East Bay MUD, were used to evaluate hydrologic processes and confirm inputs for ground-water flow models developed to estimate the effects of injection. Depth-dependent water-quality and velocity-log data were collected from wells to measure the flow of water between aquifers for pumped and unpumped conditions.
\end{abstract}

Nobel gas data were used to determine the timing of natural recharge and to evaluate contributions from focused recharge sources, such as infiltration of winter streamflows, and from diffuse sources, such as direct infiltration of precipitation (Stute and Schlosser, 2000). Nobel gas data, corrected for excess air concentrations, indicate recharge temperatures ranging from 11.0 to $18.3^{\circ} \mathrm{C}$. The average annual air temperature in the study area is $13.2^{\circ} \mathrm{C}$ and the average winter air temperature is $9.0^{\circ} \mathrm{C}$. Depending on the thickness of the unsaturated zone, recharge temperatures at the water table are typically between 0.4 and $1.4^{\circ} \mathrm{C}$ greater than the average air temperatures (Stute and Schlosser, 2000). Cooler recharge temperatures are consistent with water recharged from winter stormflows directly to the water table. Warmer recharge temperatures are consistent with water recharged by direct infiltration of precipitation through a thick unsaturated zone. Nobel gas data suggest that both recharge processes occur at this site.

Oxygen-18 $\left(\delta^{18} \mathrm{O}\right)$ and deuterium $(\delta \mathrm{D})$ data were used to determine if leakage from water supply and sewer pipes is a large source of ground-water recharge. Previous researchers believed this was the largest source of ground-water recharge to aquifers underlying the East Bay Plain (Muir, 1996). The median $\delta^{18} \mathrm{O}$ and $\delta \mathrm{D}$ composition of fresh water from wells was -6.6 and -44 per mil, respectively. These values are only slightly lighter than the median isotopic composition of precipitation (-6.1 and -39 per mil, respectively) in coastal California (measured at Santa Maria, California about 250 miles south of the study area) (International Atomic Energy Agency, 1981). The $\delta^{18} \mathrm{O}$ and $\delta \mathrm{D}$ composition of imported water from the Sierra Nevada is about -12 and -82 per mil, respectively, and is more negative than water from wells in the study area suggesting that recharge from leaking water-supply and sewer pipes may not be as large a source of recharge as previously believed.

Depth-dependent water samples collected from wells and trace-element data were used to determine the sources of high chloride concentrations in water from wells. The high chloride concentrations measured in water from wells completed in deep aquifers were believed the result of seawater that intruded from San Francisco Bay and entered these aquifers through gaps in confining clay layers or through the casings of wells (San Francisco Regional Water Quality Control Board, 1999). The downward flow of high-chloride water from the overlying aquifers intruded by seawater into the deep aquifers was measured at one well which demonstrated that this process can occur. However, the quantity of water moving through this well was small, about 0.1 acre-feet per year. Highchloride water from surrounding and underlying partly consolidated deposits also may be a source of high-chloride water to wells. For example, the depth-dependent samples of water collected from selected wells at depths of 1,000 feet below land surface have chloride concentrations as high as $640 \mathrm{mg} / \mathrm{L}$. Iodide and other trace-element 
concentrations in water from these depths are similar to concentrations in water from the partly consolidated deposits that underlie coastal aquifers in other parts of California (Piper, Garrett, and others, 1953; Izbicki, 1991) and this water may be a source of contamination to deep aquifers as injected water is withdrawn.

Carbon-14 data were used to evaluate the age of water from wells and the isolation of deep aquifers from surface sources of recharge and contamination. Water from the deep aquifer at the proposed injection/recovery site had a carbon-14 activity of 18.9 percent modern carbon (pmc) and an interpreted age of 9,400 years before present. These data suggest that the deep aquifer is isolated from surface sources of recharge and, presumably, from surface sources of contamination. A regional ground-water flow model, with a particle-tracking package, was used to simulate the movement of a particle of ground-water as it flowed from recharge areas to the injection site and to calibrate aquifer porosity values (Dan Wendel, CH2M-Hill, Inc., oral commun., 2000).

\section{References Cited}

CH2M-Hill, Inc., 2000, Regional hydrogeologic investigation of the south East Bay Plain, Oakland, Calif.: variously paged.

Fugro West, Inc., 1998, East Bay injection/extraction groundwater pilot project well construction and performance testing Oro Loma Phase III injection/extraction well--summary of operations report: Ventura, Calif. Fugro West, Inc., variously paged.

Fugro West, Inc., 1999, Oakport groundwater storage pilot project: Volume I--Technical Memorandum Number 3, Phase 2 field investigation, Ventura, Calif., Fugro West, Inc., variously paged.

International Atomic Energy Agency, 1981, Statistical treatment of environmental isotope data in precipitation, Technical Report Series, No. 206, 255 p.

Izbicki, J.A., 1991, Chloride sources in a California coastal aquifer. in: Peters, Helen, ed., Ground water in the Pacific Rim countries: American Society of Civil Engineers, IR Div/ ASCE Proceedings, p. 71-77.

Muir, K.S., 1996, Classification of ground water recharge potential in the East Bay Plain area, Alameda County, California: Hayward, Calif., Alameda County Flood Control and Water Conservation District, C-92-320, $10 \mathrm{p}$.

Piper, A.M., Garrett, A.A., and others, 1953, Native and contaminated ground waters in the Long Beach-Santa Ana areas, California: U.S. Geological Survey Water-Supply Paper 1136, 320 p.

San Francisco Regional Water Quality Control Board, 1999, East Bay Plain groundwater basin beneficial use evaluation report, Oakland, Calif., variously paged.

Stute, Martin, and Schlosser, Peter, 2000, Atmospheric noble gasses, chap. 11, in: Cook, Peter, and Herezeg, A.L., eds., Environmental tracers in subsurface hydrology: Boston, Kluwer Academic Publishers, pp. 349-377. 


\title{
Feasibility of Regional-Scale Aquifer Storage and Recovery (ASR): Scientific Uncertainties
}

Carl R. Goodwin (cgoodwin@usgs.gov)

U.S. Geological Survey, 227 N. Bronough St., Suite 3015, Tallahassee, Florida 32301

\begin{abstract}
The concept of pumping water underground during times of excess supply and recovering the same water later to supplement supplies is attractive as a water management tool. In fact, aquifer storage and recovery (ASR) is functioning well in many localized areas throughout the country. The application of this concept on a regional scale is a logical next step and is being proposed as a key component of the Comprehensive Everglades Restoration Plan.
\end{abstract}

In areas of potential regional-scale ASR application such as south Florida, there are several significant scientific uncertainties that must be addressed to help assure that societal expenditures on such ventures are scientifically well founded and are afforded the greatest chance of success. Scientific uncertainties span a variety of disciplines, including hydrogeology, geochemistry, and microbiology. Uncertainties can be framed as questions whose answers are presently either unknown, only known in a very general way, or expected to be within a very large range of possibilities. Some examples are:

- How will local and regional aquifer pressures change, and what are the implications of such changes?

- How far will the recharged water migrate into the targeted zone?

- What will be the extent of mixing recharge with native aquifer water?

- How much of the recharged water will be recoverable?

- How will recharge water, native aquifer water, and aquifer materials interact to affect the chemistry of recovered water?

- Will trace elements and radionuclides be mobilized during storage of water in the aquifer?

- How do subsurface microbial communities respond to recharged water?

- What is the fate and transport of introduced pathogens?

- Will chemical reactions between mixing waters alter the matrix of the aquifer substrate?

This presentation addresses and expands upon these scientific uncertainties, using schematics and animation sequences to better explain the concepts. 


\title{
Why do Bacteria Colonize Aquifer Surfaces? Geochemical and Nutrient Controls of Bacterial Colonization of Silicate Surfaces
}

\author{
Jennifer Roberts Rogers (jrrogers@ku.edu) \\ Dept. of Geology, University of Kansas
}

\section{Introduction}

It has long been recognized that colloid-sized particles, including microorganisms, are transported through porous media (see review by Gerba and Bitton, 1984). The implications of this are of obvious importance when pathogens are involved, due to public health concerns. However, the transport of microorganisms may also have important implications of a geological or environmental nature. Microorganisms are the primary recyclers of organic carbon in aquifers, gaining energy but discarding carbon dioxide, methane, and other organic byproducts back to the groundwater. These processes can often shift geochemical equilibria by dissolving and precipitating mineral phases. In contaminated aquifers, indigenous degradative microorganisms can bioremediate groundwater contaminants, but these efforts may fail if intense bacterial attachment and growth clog sediment pores.

The transport of microorganisms through porous media has long been recognized and modeled (e.g., Campbell Rehman and others, 1999). Bacterial transport in the subsurface is controlled by advection/dispersion, attachment/detachment to the solid matrix, growth phase and type of bacteria, as well as cell shape. Colloid filtration and surface interactions between bacteria and surfaces control attachment, with surface influences like electrostatic interactions, hydration forces, hydrophobic and steric interactions, and polymer bridging affecting attachment (Elimelech and others, 1995). Bacterial adhesion may be influenced by many factors including mineral and bacterial surface charges, mineral surface roughness and surface alteration, glycocalyx formation, predation, and competition. In aquifers, bacteria are often transported at a rate less than that of the flowing groundwater, leading to various representations of retardation mechanisms in models. Over the past decade, efforts have been made to characterize bacterial attachment thermodynamically through surface/solution or by using the Derjaguin-LadauVerwey-Overbeek (DLVO) theory to model electrostatic interactions (see review by Hermansson, 1999). Physical and hydrologic parameters also influence bacterial transport. Aquifer heterogeneities may create preferential flow paths that transport bacteria, while cell size may limit transport to larger conduits or fractures (e.g., McKay and others, 1993).

Solution chemistry, including $\mathrm{pH}$, DOC (dissolved organic carbon), and nutrients, is known to affect microbial attachment behavior (Mueller, 1996). Researchers have found that the attachment behavior of Pseudomonas fluorescens decreases between $\mathrm{pH} 5.5$ to 7 to silica beads and with decreasing ionic strength (e.g., Deshpande and Shonnard, 1999). Field observations suggest that the number of free-living organisms increases within contaminant plumes where cells are capable of active attachment and detachment (e.g., Savage and Fletcher, 1985). In dilute or oligotrophic environments attachment may benefit microorganisms due to surface-associated organic matter.

It is proposed here that microorganisms preferentially attach to surfaces that are nutritionally advantageous when those surfaces have similar electrostatic characteristics. In nutrient-limited environments, irreversible attachment of bacteria to silicate surfaces occurs predominantly to those surfaces from which the limiting nutrients $(\mathrm{P} / \mathrm{Fe})$ can be leached. In environments rich in dissolved nutrients, colonization occurs predominantly on silicate surfaces with the greatest coulombic attraction for the cells.

\section{Methods}

The study aquifer is a petroleum contaminated groundwater near Bemidji, MN, part of the USGS Toxic Substances Hydrology program. Groundwater in the study zone is completely anaerobic; a representative water has a pH of 6.6, with $3.7 \mathrm{mmol} \mathrm{l}^{-1} \mathrm{DOC}, 0.7 \mathrm{mmol} \mathrm{l}^{-1} \mathrm{Fe}^{2+}$, and $1.0 \mathrm{mmol} \mathrm{l}^{-1} \mathrm{Si}$. The bulk solution has $4.3 \mathrm{mmol}^{-1} \mathrm{Ca}^{2+}$, $1.5 \mathrm{mmol} \mathrm{l}^{-1} \mathrm{Mg}^{2+}$, with $11.3 \mathrm{mmol} \mathrm{l}^{-1} \mathrm{HCO}_{3}{ }^{-}$and $<0.01 \mathrm{mmol}{ }^{-1}$ of $\mathrm{Al}, \mathrm{K}, \mathrm{Na}, \mathrm{SO}_{4}, \mathrm{NO}_{3}$, and $\mathrm{PO}_{4}(\mathrm{Bennett}$ and others, 2000). Changes in groundwater chemistry in the anaerobic zone suggest silicate weathering, and evidence for accelerated dissolution of feldspars and quartz with precipitation of clay minerals has been reported (Bennett and others, 2000; 2001). Dissimilatory iron reducing bacteria (DIRB) are the dominant hydrocarbon degrading guild 
within the study zone, as assessed by most probable number analysis (MPN) (Bekins and others, 1999), producing high concentrations of $\mathrm{Fe}^{2+}$.

Microbial colonization of silicates was characterized using the in situ microcosm method (Hiebert and Bennett, 1992). A selection of silicates were used in field experiments because they contain varying amounts of $\mathrm{P}$ and $\mathrm{Fe}$ occurring as apatite needles and iron oxides, respectively (Rogers and others, 1998) including anorthoclase ( $\mathrm{P}=$ 1050 ppm, $\mathrm{Fe}_{2} \mathrm{O}_{3}=4.4 \%$ ), South Dakota (S.D.) microcline ( $\mathrm{P}=1200$ ppm, $\mathrm{Fe}_{2} \mathrm{O}_{3}=0.9 \%$ ), Ontario (O.) microcline $\left(\mathrm{P}<50\right.$ ppm, $\left.\mathrm{Fe}_{2} \mathrm{O}_{3}=1.8 \%\right)$, plagioclase $\left(\mathrm{P}<50 \mathrm{ppm}, \mathrm{Fe}_{2} \mathrm{O}_{3}=1.0 \%\right)$, and a crystalline Columbia River basalt $(\mathrm{P}$ $=3000 \mathrm{ppm}, \mathrm{Fe}_{2} \mathrm{O}_{3}=14.0 \%$ ). The silicates were crushed and sieved to a $1-5 \mathrm{~mm}$ size fraction, cleaned by lowpower sonication and dry sterilized at $125^{\circ} \mathrm{C}$. The fragments were transferred to sterile polyethylene flow-through microcosms, and suspended in the aquifer for 3 months. Additional microcosms were reserved for reference and control. Groundwater samples were taken at the time of microcosm placement and removal.

Streaming potentials of mineral surfaces were measured to obtain information about grain surface charge characteristics. Samples were analyzed in a $10 \mathrm{mM} \mathrm{KCl}$ solution using a streaming potential analyzer equipped with a cylindrical cell and Ag electrodes (Brookhaven). Streaming potentials were converted to zeta potentials using the Helmholtz-Smoluchowski equation and the Fairbrother and Mastin approach (Elimelech and others, 1994).

After reaction in the aquifer, microcosms were recovered anaerobically, samples were taken and immediately processed for MPN using the methods of Bekins, and others (1999). Additional samples were preserved for scanning electron microscopy (SEM). Samples were fixed in the field using chemical critical point drying (Vandevivere and Bevaye, 1993) with method blanks to insure that the surface was not altered during fixation.

\section{Surface Colonization}

Microorganisms colonize some silicate surfaces to a greater degree than others, with weathering correlating directly with the extent of colonization. Only those silicates which contain phosphorus were colonized, and this only occurred in the anaerobic groundwater (e.g., Rogers and others, 1998).

SEM examination of mineral surfaces after reaction in the aquifer showed that plagioclase and the Ontario

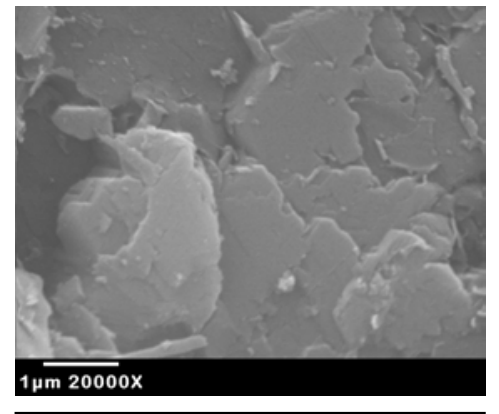

Figure 1. Non-P bearing microcline after exposure to microbially active groundwater for 6 months. No bacterial colonization is observed.

microorganisms can utilize the $\mathrm{P} / \mathrm{Fe}$ in silicates and further, that the increased availability of these nutrients results in microbial growth and colonization only on those surfaces. Our previous research has established that increased biomass correlates directly with the presence of $\mathrm{P}$ in laboratory experiments and that microorganims are capable of extracting and utilizing $\mathrm{P}$ from silicates (Rogers and others, 2001). This is consistent with the findings of other researchers that microorganisms derive many essential trace elements from silicate rocks (Brantley and others, 2001). 
While the extent of colonization correlates to the presence of $\mathrm{P}$ and Fe in silicates, there is no direct correlation between zeta potential and colonization. At neutral $\mathrm{pH}$ the feldspars and silicates used in these experiments should be uniformly negatively charged according to published $\mathrm{pH}_{z \mathrm{pc}}$ values. This is evidenced by measured zeta potentials (Table 1). The P-bearing silicates have more negative zeta potentials, yet these surfaces exhibit the greatest attachment. These results suggest that the distribution of microorganisms on different mineral surfaces in situ may be related, in part, to the nutrient content of silicates and not exclusively coulombic attraction between the cells and the mineral surfaces. However, in environments where nutrients are available or on surfaces that are positively-charged (e.g., iron oxides), it is expected that coulombic forces will dominate this interaction.

Table 1. Summary of results from in situ microcosm minerals after exposure to carbon-rich groundwater.

\begin{tabular}{|c|c|c|c|c|c|c|}
\hline Mineral/Rock & $\mathrm{C}$ & G & W & $\mathrm{P}$ & $\mathrm{Fe}$ & $\mathrm{mV}$ \\
\hline $\begin{array}{l}\text { Anorthoclase } \\
\text { Basalt } \\
\text { S.D. Microcline } \\
\text { O. Microcline } \\
\text { Plagioclase }\end{array}$ & $\begin{array}{l}++++ \\
++++ \\
++ \\
-- \\
--\end{array}$ & $\begin{array}{l}+++ \\
+ \\
-- \\
-- \\
--\end{array}$ & $\begin{array}{l}\text { ++++ } \\
+++ \\
++ \\
-- \\
--\end{array}$ & $\begin{array}{l}+++ \\
++++ \\
+++ \\
--\end{array}$ & $\begin{array}{l}++ \\
++++ \\
-- \\
+ \\
--\end{array}$ & $\begin{array}{l}-37.0 \\
* * \\
-36.0 \\
-25.0 \\
* *\end{array}$ \\
\hline \multicolumn{7}{|c|}{$\begin{array}{l}\text { Increasing density of colonization }(\mathrm{C}) \text {, glycocalyx }(\mathrm{G}) \text {, surface weathering }(\mathrm{W}) \text {, and } \\
\text { presence of mineral phosphorus }(\mathrm{P}) \text { and iron }(\mathrm{Fe}) \text { are indicated by }+ \text { through }++++.-- \\
\text { indicates that the feature was not observed. Zeta potential at } \mathrm{pH}=7 \text { is expressed in } \mathrm{mV} \\
* * \text { indicates the silicate was not investigated. }\end{array}$} \\
\hline
\end{tabular}

MPN analysis of the silicate chips confirms that P-bearing silicates and specifically silicates containing $\mathrm{P}$ and Fe support more biomass than non-nutrient silicates (Figure 3). DIRB are the most numerous physiologic type on silicate surfaces, although methanogens and fermenters are detected. Fe-bearing anorthoclase and basalt are dominated by DIRB, while SD microcline and plagioclase dislpay more balanced populations. The dominance of DIRB on Fe-bearing surfaces may indicate that these cells out-compete other metabolic guilds in the presence of iron or are actually growing and increasing their biomass once attached. Colonization on anorthoclase and basalt may be advantageous to this population by providing two necessary nutrients in one place. Because Fe(III) is used as a terminal electron acceptor (TEA) by DIRB, these organisms may have a competitive advantage when a silicate provides both $\mathrm{P}$ and the

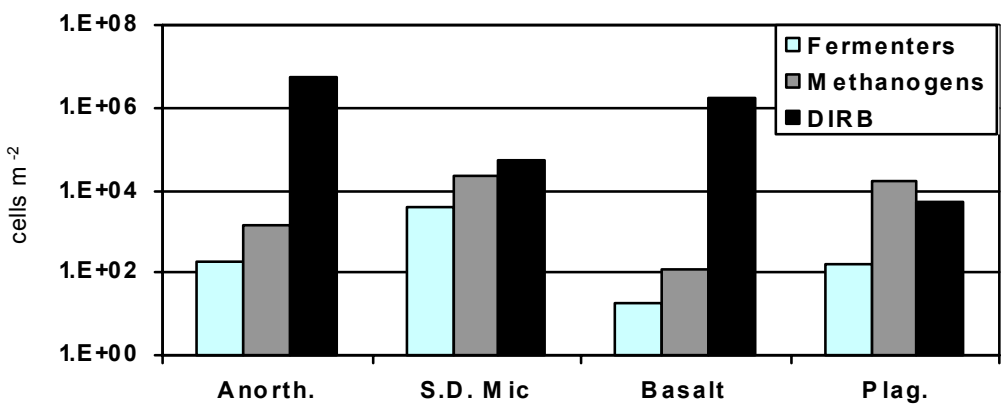
necessary TEA.

\section{Implications}

One implication of the observed nutrient-driven colonization is that the transport of bacteria through porous media may be controlled not only by surface charge and groundwater conditions, but also by the mineral composition of the aquifer material. Small compositional changes in sediment mineralogy could have potentially tremendous impacts on which cells are transported and how fast they are transported. Conversely, the ability of bacteria to attach and grow on nutrient-rich rocks, while leaving non-nutrient rocks barren, suggests the potential for preferential clogging of the most reactive mineral surfaces and flow paths. 


\section{References}

Bekins, B.A., Godsy, E.M., and Warren, E., 1999, Distribution of microbial physiologic types in an aquifer contaminated by crude oil: Microbial Ecology, v. 37, p. 263-275.

Bennett, P.C., Hiebert, F.K., and Rogers, J.R., 2000, Microbial control of mineral-groundwater equilibria macroscale to microscale: Hydrogeology Journal, v.8, p. 47-62.

Bennett, P.C., Rogers, J.R., Hiebert, F.K., and Choi, W.J., 2001, Silicates, silicate weathering, and microbial ecology.: Geomicrobiology Journal, v. 18, p. 3-19.

Brantley, S.L., Lierman, L.J., Bau, M., and Wu, S., 2001, Uptake of trace metals and rare earth elements from hornblende by a soil bacterium: Geomicrobiology Journal, v. 18, p. 37-61.

Campbell Rehman, L.L., Welty, C., and Harvey, R.W., 1999, Stochastic analysis of virus transport in aquifers: Water Resources Research, v. 35, no. 7, p. 1987-2006.

Deshpande, P.A., and Shonnard, D.R., 1999, Modeling the effects of systematic variation in ionic strength on the attachment kinetics of Pseudomonas fluorescens UPER-1 in saturated sand columns: Water Resources Research, v. 35, p. 1619-1627.

Elimelech, M., Chen, W.H., and Waypa, J.J., Desalination., Vol. 95(3), July 1994, pages 269-286., 1994, Measuring the Zeta (Electrokinetic) Potential of Reverse Osmosis Membranes by a Streaming Potential Analyzer: Desalination, v. 95, no. 3, p. 269-286.

Elimelech, M., Gregory, J., Jia, X., and Williams, R., 1995, Particle Deposition and Aggregation: Measurement, Modeling and Simulation: Newton, MA, Butterworth-Heineman.

Gerba, C.P., and Bitton, G., 1984, Microbial pollutants: their survival and transport pattern to groundwater, in Bitton, G., and Gerba, C.P., eds., Groundwater Pollution Microbiology: New York, John Wiley and Sons, p. 225-233.

Hermansson, M., 1999, THe DLVO therory in microbial adhesion: Colloids and Surfaces, v. B14, p. 105-119.

Hiebert, F.K., and Bennett, P.C., 1992, Microbial control of silicate weathering in organic-rich ground water: Science, v. 258, no. 5080, p. 278-281.

McKay, L.D., Cherry, J.A., Bales, R.C., Yahya, M.T., and Gerba, C., 1993, A field example of bacteriophage as tracers in fractured flow: Environmental Science and Technology, v. 27, p. 1075-1079.

Mueller, R.F., 1996, Bacterial transport and colonization in low nutrient environments: Water Research, v. 30, no. 11, p. 2681-2690.

Rogers, J.R., Bennett, P.C., and Choi, W.J., 1998, Feldspars as a source of nutrients for microorganisms: American Mineralogist, v. 83, p. 1532-1540.

Rogers, J.R., Bennett, P.C., and Choi, W.J., 2001, Enhanced weathering of silicates by subsurface microorganisms: a strategy to release limiting inorganic nutrients?, in Water Rock Interaction, Villasmius, Sardinia.

Savage, D.C., and Fletcher, M., 1985, Bacterial Adhesion, Mechanisms, and Physiological Significance: New York, Plenum Press.

Vandevivere, P., and Bevaye, P., 1993, Improved preservation of bacterial exopolymers for scanning electron microscopy: Journal of Microscopy, v. 167, p. 323-330. 


\title{
Fate And Transport of Bacterial, Viral, and Protozoan Pathogens During ASR Operations- What Microorganisms Do We Need To Worry About And Why?
}

\author{
David Metge (dwmetge@usgs.gov) \\ U.S. Geological Survey, Boulder, Colorado 80303 http://wwwbrr.cr.usgs.gov/bacteria
}

\begin{abstract}
Deteriorating ground-water quality has stimulated new research initiatives; that, in part focus on the subsurface fate and transport behavior of pathogens. Increasing application of aquifer storage and recovery (ASR) operations has brought the issue of fate and transport of microbial pathogens into sharper focus. Because ASR practices are becoming widespread, they are found within diverse geohydrologic regimes. This is coupled with modest, recent regulatory guidance and limited understanding of how pathogens within the subsurface are affected by this type of water handling. These factors make the study of pathogen fate and transport within ASR systems extremely difficult. A major challenge in assessing the utility of ASR is to identify the pathogens that may pose a threat in each ASR setting. Another concern is how best to study the role of pathogens upon water quality during ASR operations.
\end{abstract}

There are several factors that influence survival of enteric microorganisms within ground water matrices. These include temperature, salinity, dissolved oxygen (DO), $\mathrm{pH}$, microbial size, predation, metal/nutrient availability, and microbial growth. Dissolved oxygen and temperature are among the most significant factors in loss of enteric virus infectivity and bacterial activity. Below $10 \mathrm{C}$, many viruses can survive for months or even years. In contrast, at higher temperatures greater than $20 \mathrm{C}$, inactivation of most viruses occurs rapidly. In Florida, ASR temperatures range from $22-28 \mathrm{C}$; these conditions promote both enteric bacterial and viral die off. Currently, there is little data on enteric protozoa (i.e., Cryptosporidium, and Giardia lamblia) survival in ground water. Thus, different conditions may promote or inhibit microbial survival and may be site-specific. Nevertheless, regular screening for coliform bacteria, indicator virus and Cryptosporidium should be undertaken.

In order to adequately describe subsurface transport behavior of microbial pathogens and address public safety and ground-water quality issues, surrogates (well-characterized microbial-sized microspheres; nonpathogenic, fluorescently labeled bacteria and protozoa; and bacteriophage) can be used in lieu of microbial pathogens in flow-through column and field injection and recovery experiments. Controlled field and lab experiments are generally conducted to study effects of trace organic contaminants (e.g., surfactants) and microbial properties (surface chemistry, size, and buoyant density) on movement of microbial surrogates through aquifer sediments. Results are then applied to the predicted subsurface transport behavior of pathogens, assuming that the pathogens would be affected by these factors in a similar manner. These results also provide attenuation rates for selected pathogens within groundwater at artificial recharge sites. A recently developed stochastic model indicated that the degree of aquifer heterogeneity helped govern the degree of viral transport within granular media; these types of data would help water utilities and regulators determine pretreatment requirements and predict water quality changes within aquifer storage and recovery systems.

Current studies show that slight differences in ground-water matrices impact the degree of subsurface microbial transport. It should be recognized that surface waters injected underground during ASR operations can have different physicochemical characteristics than the ground-water they displace. However, it is unknown if introduction of waters with different geochemical characteristics accelerate, inhibit or modify naturally occurring rock-water interactions and microbial-sediment interactions. These modifications may be operational on regional scales. A further complication is that different states have different regulations about ASR practices. Adequate water quality is most often obtained by chlorination before water is placed into aquifers. Though this prevents clogging and allows introduction of potable water to the aquifer, chlorination is well known to be less effective against viruses and protozoa (specifically Cryptosporidium). Therefore, the survival and fate these microorganisms and enteric bacteria in the vicinity of ASR schemes requires closer scrutiny. 


\section{References}

Harvey, R.W. and S.P. Garabedian, Use of colloid filtration theory in modeling movement of bacteria through a contaminated sandy aquifer. Environmental Sciences and Technology, 1991. 25: p. 178-185.

Harvey, R.W., et al., Transport Behavior of Groundwater Protozoa and Protozoan-Sized Microspheres in Sandy Aquifer Sediments. Applied and Environmental Microbiology, 1995. 61(1): p. 209-217.

Harvey, R.W., In situ and laboratory methods to study subsurface microbial transport., in Manual of Environmental Microbiology, C.J. Hurst, et al., Editors. 1997, American Society for Microbiology Press, Inc.: Washington, DC. p. 586-599.

Harvey, R.W., et al., Physiological considerations in applying laboratory-determined buoyant densities to predictions of bacterial and protozoan transport in groundwater: Results of in-situ and laboratory pests. Environmental Science \& Technology, 1997. 31(1): p. 289-295.

5Pieper, A.P., et al., Transport and recovery of bacteriophage PRD1 in an unconfined sand aquifer: effect of anthropogenic organic material. Environmental Sciences and Technology, 1997. 31: p. 1163-1170.

Rehmann, L.L.C., C. Welty, and R.W. Harvey, Stochastic analysis of virus transport in aquifers. Water Resources Research, 1999. 35(7): p. 1987-2006.

Ryan, J.N. and P.M. Gschwend, Effects of Ionic-Strength and Flow-Rate on Colloid Release - Relating Kinetics to Intersurface Potential-Energy. Journal of Colloid and Interface Science, 1994. 164(1): p. 21-34.

Ryan, J.N. and P.M. Gschwend. Effect of solution chemistry on the detachment of clay colloids from an iron oxidecoated sand. Environmental Sciences and Technology, 1994. 28: p. 1717-1726.

Ryan, J.N., et al., Bacteriophage PRD1 and silica colloid transport and recovery in an iron oxide-coated sand aquifer. Environmental Science \& Technology, 1999. 33(1): p. 63-73.

US EPA, The Class V Underground Injection Control Study: Volume 7 Sewage Treatment Effluent Wells. 1999, US EPA: Washington, DC. p. 127. 


\title{
Detection of Microbial Indicators and Human Microbial Pathogens in Artificial Recharge Studies
}

\author{
Dale W. Griffin, Ph.D., MSPH (dgriffin@usgs.gov) \\ U.S.Geological Survey Center for Coastal Studies, St. Petersburg, Florida 33701
}

\begin{abstract}
One of the needs in studying artificial recharge is determining microbial water quality within the recharge zone. Indicator organisms such as the fecal coliforms and alternate indicators such as enterococci, Clostridium perfringens and bacteriophage can be used to determine if a recharge zone is being impacted by viable microorganisms of fecal origin via the recharge water source or surrounding contaminated ground waters. Using emerging technologies, some indicator organisms such as Escherichia coli (a fecal coliform), enterococci and certain types of bacteriophage (viruses whose hosts are bacteria) can be used to determine the source of the pollution when questions arise concerning human versus animal inputs. Examples of emerging technologies that have allowed this type of resolution include ribotyping (DNA fingerprinting of bacteria isolates) and genetic probe assays (group typing of $\mathrm{F}^{+}$specific RNA coliphage). The alternate to determining source via these types of assays are to screen water samples for host specific pathogens (human or animal). One group of host specific pathogens are the human enteroviruses (a group which includes polioviruses, echoviruses and Coxsackie viruses) and Hepatitis A viruses. These viruses have successfully been utilized by a number of researchers to determine if human waste was impacting a given body of water. Assays that are utilized to determine the presence of these pathogens include cell culture and many variants of the polymerase chain reaction (PCR).
\end{abstract}

Another useful tool in determining the susceptibility of a recharge zone to contamination or in determining the potential impact of recharge water on surrounding ground waters is tracer studies. Tracer studies can be carried out with gases, dyes and/or microorganisms. A number of tracer studies, which utilized bacteriophage to determine wastewater/groundwater movement, have been successfully carried out in the State of Florida. A common trend that was noted in these studies was that the phage tracers typically moved faster than dye tracers that were or had been utilized in the same regions for similar purposes. One of the conclusions from these studies was that phage tracers better reflect actual microbial groundwater movement.

This presentation will cover the microorganisms of interest and the methodology used to determine microbe presence and viability in groundwater studies. Issues such as source tracking, selection of the appropriate organism or suite of organisms and the pros and cons of various methodologies will be addressed. Below are several papers where many of these issues are addressed.

\section{References}

Griffin, D., C.J. Gibson III, E.K. Lipp, K. Riley, J.H. Paul, and J.B. Rose (1999). Detection of Viral Pathogens by Reverse Transcriptase PCR and of Microbial Indicators by Standard Methods in the Canals of the Florida Keys. Applied and Environmental Microbiology 65(9): 4118-4125.

Griffin, D.W., E.K. Lipp, M. McLaughlin and J.B. Rose (2001). Marine Recreation and Public Health Microbiology: Quest for the Ideal Indicator. BioScience 51(10): 817-825

Harvey, R.W. (1997). Microorganisms as tracers in groundwater injection and recovery experiments: A review. FEMS Microbiology Reviews 20(3-4): 461-472

Paul, J.H., J.B. Rose, S.C. Jiang, X. Zhou, P. Cochran, C. Kellogg, J.B. Kang, D. Griffin, S. Farrah and J. Lukasik. (1997). Evidence for Groundwater and Surface Marine Water Contamination by Waste Disposal Wells in the Florida Keys. Water Research 31(6) :1448-1454

Yates, M.V. and Yates S.R. (1988). Modeling Microbial Fate in the Subsurface Environment. CRC Critical Reviews in Environmental Control. 17(4): 307-344 


\title{
Microbial Strategies for Degradation of Organic Contaminants in Karst
}

\author{
Tom D. Byl (tdbyl@usgs.gov), Gregg E. Hileman ${ }^{1}$ (ghileman@usgs.gov), Shannon D. \\ Williams ${ }^{1}$ (swilliam@usgs.gov), David W. Metge ${ }^{2}$ (dwmetge@usgs.gov), and Ron W. \\ Harvey $^{2}$ (rwharvey@usgs.gov) \\ ${ }^{1}$ U.S. Geological Survey 640 Grassmere Park, Suite 100, Nashville Tennessee 37211 \\ ${ }^{2}$ U.S. Geological Survey, Boulder, Colorado 80303
}

\begin{abstract}
Approximately 40 percent of the United States east of the Mississippi River is underlain by various types of karst aquifers (Quinlan, 1989) and more than two-thirds of the State of Tennessee is underlain by carbonate rocks and can be classified as karst (Wolfe and others, 1997). Potential industrial sources of ground-water contamination are common in karst regions; however, the fate and transport of contaminants such as fuels in karst areas are poorly understood because of the distinctive hydraulic characteristics of karst aquifers (Field, 1993). Ground-water models that predict the fate and transport of contaminants in sandy aquifers have limited application to karst aquifers. Most natural attenuation and bioremediation guidelines specify that they are not applicable in fractured rock or karst aquifers (U.S. Environmental Protection Agency, 1997).
\end{abstract}

The lack of studies examining biodegradation in karst aquifers may be due to the widespread perception that contaminants are rapidly flushed out of karst aquifers. In highly developed and well-connected conduit systems, the rate of contaminant migration is expected to be much faster than the rate of biodegradation. Field (1993) states that remediation techniques such as ground-water extraction or bioremediation are impractical in karst aquifers dominated by conduit flow; however, he also states that the belief that contaminants are rapidly flushed out of karst aquifers is a popular misconception. Large volumes of water may be trapped in fractures along bedding planes and other features isolated from active ground-water flowpaths in karst aquifers (Wolfe and others, 1997). In areas isolated from the major ground-water flowpaths, contaminant migration may possibly be slow enough that biodegradation could reduce contaminant mass if favorable microorganisms, food sources, and geochemical conditions are present (Byl and Williams, 2000; Byl and others, 2001). The capacity for biodegradation processes in a karst setting was evaluated at sites in Tennessee and Kentucky.

The potential for biodegradation of trichloroethylene (TCE) was studied in a karst aquifer at Lewisburg, Tennessee. This site was selected because of the presence of TCE degradation by-products in the karst aquifer, available site hydrologic and chlorinated-ethene information. Additional chemical, biological and hydrological data were gathered to evaluate if the occurrence of TCE degradation by-products in the karst aquifer was the result of biodegradation in the aquifer or simply transport into the aquifer. Geochemical analysis established that sulfatereducing conditions, essential for reductive dechlorination of chlorinated solvents, existed in parts of the contaminated karst aquifer. Geochemical conditions in other areas of the aquifer fluctuated between anaerobic and aerobic conditions and contained compounds associated with cometabolism, such as ethane, methane, ammonia and dissolved oxygen. A large, diverse bacteria population inhabits the contaminated aquifer. Bacteria known to biodegrade TCE and other chlorinated solvents, such as sulfate-reducers, methanotrophs, and ammonia-oxidizers, were identified from karst-aquifer water using the RNA-hybridization technique. Results from microcosms using raw karst-aquifer water found that aerobic cometabolism and anaerobic reductive dechlorination degradation processes were possible when appropriate conditions were established in the microcosms. The chemical and biological results provide circumstantial evidence that several biodegradation processes are potentially active in the karst aquifer. Additional site hydrologic information was developed to determine if appropriate conditions persisted long enough in the karst aquifer for these biodegradation processes to be significant. Continuous monitoring devices placed in four wells during the spring of 1998 documented a dual phase ground-water flow system within the karst aquifer. Dynamic areas were present within the karst aquifer where active flow occurred, as well as, stable areas in the karst aquifer that were isolated from active flow. The $\mathrm{pH}$, specific conductance, low dissolved oxygen levels and low oxidation-reduction potentials changed very little in the stable areas isolated from active flow. The stable areas in the karst aquifer had geochemical conditions and bacteria conducive to reductive dechlorination of chlorinated ethenes. The dynamic areas of the karst aquifer associated with active flow fluctuated between anaerobic and aerobic conditions in response to rain events. Associated with this dynamic environment were 
bacteria and geochemical conditions conducive to cometabolism. In summary, multiple lines of evidence developed from biological, chemical and hydrological data demonstrate that a variety of biodegradation processes were active in this karst aquifer.

A second karst-aquifer site contaminated with jet fuel was also investigated. The site is located at an airfield in southern Kentucky. Ground-water samples were collected for bacteria and geochemical analysis from several contaminated monitoring wells in an unconsolidated regolith and karst aquifer that had varying concentrations of dissolved fuel. Bacteria counts ranged from approximately 700,000 bacteria per milliliter to 1.2 million depending on the well and sample collection time. These bacteria counts were derived using two methods, direct counts and BART growth tests, and the results of the two tests were within 20 percent of each other. These numbers are much greater than previously reported when tryptic soy agar was used to quantify heterotrophic bacteria in the same wells (Byl and others, 2001). Bacteria from the fuel-contaminated part of the karst aquifer had a 5\% lighter buoyant density and a wider range of sizes than the bacteria from the non-contaminated well. Additionally, bacteria isolated from fuel-contaminated ground-water samples readily grew with dissolved gasoline as the only source of food. Static microcosms $(n=3)$ set up using aerated raw karst water spiked with benzene at 1 $\mathrm{mg} / \mathrm{L}$ established a biodegradation rate of $50 \%$ loss $\left(\mathrm{T}_{1 / 2}\right)$ in 3 days. Sterile control microcosms had less than $10 \%$ benzene loss over the same time period. Additional field evidence that biodegradation was taking place in the aquifer was established by measuring geochemical indicators. The wells with screens intersecting non-contaminated sections of the aquifer had greater dissolved oxygen concentrations (generally above 2 milligrams per liter) than those intersecting more contaminated sections (dissolved oxygen less than 0.1 milligrams per liter). Also, where the oxygen concentrations were diminished, geochemical evidence indicated that anaerobic processes were active. This evidence includes elevated levels of ammonia, sulfide and ferrous iron in the fuel-contaminated ground-water samples. Based on these results, biodegradation of fuel constituents in the karst aquifer is indicated, and therefore, natural attenuation should not be disregarded because of preconceptions about low microbial activity in karst aquifers.

\section{References}

Byl, T.D., and Williams, S.D., 2000, Biodegradation of Chorinated ethenes at a karst site in Middle Tennessee. U.S. Geological Survey Water-Resources Investigations Report 99-4285, 58 pages. Also available at http://pubs.water.usgs.gov/wri994285

Byl, T.D., Hileman, G.E., Williams, S.D., and Farmer, J.J., 2001, Geochemical and microbial evidence of fuel biodegradation in a contaminated karst aquifer in southern Kentucky, June 1999, in U.S. Geological Survey Karst Interest Group Proceedings, St. Petersburg, Florida, February 13-16, 2001. E.L. Kuniansky, ed., WRIR 01-4011, pages 151-156.

Field, M.S., 1993, Karst hydrology and chemical contamination: Journal of Environmental Systems, v. 22, no.1, p. $1-26$.

Quinlan, J.F., 1989, Ground-water monitoring in karst terranes: recommended protocols and implicit assumptions: Las Vegas, Nev., U.S. Environmental Protection Agency, Environmental Monitoring Systems Laboratory, EPA/600/X-89/050, $100 \mathrm{p}$.

U.S. Environmental Protection Agency, Region 4, 1997, Draft EPA Region 4 Suggested practices for evaluation of a site for natural attenuation (biological degradation) of chlorinated solvents, Version 3.0: Atlanta, Ga., U.S. Environmental Protection Agency, Region 4, 41 p.

Wolfe, W.J., Haugh, C.J., Webbers, Ank, and Diehl, T.H., 1997, Preliminary conceptual models of the occurrence, fate, and transport of chlorinated solvents in karst aquifers of Tennessee: U.S. Geological Survey WaterResources Investigations Report 97-4097, 80 p. 


\title{
Microbial Redox Cycling of Arsenic Oxyanions in Anoxic Environments
}

\author{
Ronald S. Oremland (roremlan@usgs.gov) \\ U.S. Geological Survey 345 Middlefield Road, Bldg. 15, Menlo Park, California 94025
}

\section{Abstract}

While we normally associate the element arsenic with poisoning and death, paradoxically it can also serve as the fundamental basis for life-giving bioenergetic reactions in certain types of microorganisms. This is not to say that microbes differ from metazoans with regard to As toxicity; indeed it is also quite toxic to them as well. However, many microorganisms have evolved a variety of plasmid encoded strategies that protect them from the deleterious effects of heavy metals, including arsenic. Most of these resistance mechanisms involve redox reactions whereby either the internal pools of cytoplasmic arsenate $[\mathrm{As}(\mathrm{V})]$ are rapidly reduced to arsenite $[\mathrm{As}(\mathrm{III})]$ for extrusion from the cell, or external As(III) is oxidized at the cell surface and denied entry into the cell. But in the case of arsenic, and to a great extent selenium as well, other anaerobic Bacteria and Archaea can actually conserve the energy gained via the oxidation of organic compounds $\left(\right.$ or $\left.\mathrm{H}_{2}\right)$ with the reduction of $\mathrm{As}(\mathrm{V})$ to $\mathrm{As}(\mathrm{III})$. This process is termed dissimilatory arsenate reduction, and is a means of anaerobic respiration that supports the growth of a number of recently discovered, phylogenetically diverse microorganisms (Figure 1). For example, growth of the bacterium Sulfurospirillum barnesii on lactate and $\mathrm{As}(\mathrm{V})$ at $\mathrm{pH} 7.0$ conforms to the following stoichiometry:

Lactate $^{-}+2 \mathrm{HAsO}_{4}{ }^{=}+3 \mathrm{H}^{+} \rightarrow$ Acetate $^{-}+2 \mathrm{H}_{3} \mathrm{AsO}_{3}+\mathrm{HCO}_{3}{ }^{-} \quad \Delta \mathrm{G}_{\mathrm{o}}{ }^{\prime}=-174 \mathrm{~kJ} / \mathrm{mole}$ lactate

Because $\mathrm{As}(\mathrm{III})$ is hydrologically more mobile and biochemically more toxic than $\mathrm{As}(\mathrm{V})$, the dissimilatory reduction of $\mathrm{As}(\mathrm{V})$ represents an important means by which arsenic can be mobilized and transported from the adsorbed solid phase into the liquid phase (Zobrist and others, 2000). This process can therefore be of importance in anoxic sediments, soils, and subsurface aquifers. Several recent reviews on this phenomenon have appeared in the literature (Newman and others, 1998; Stolz and Oremland, 1999; Oremland and Stolz, 2000; Oremland and others, 2001). In certain anoxic, arsenic-rich environments, $A s(V)$ reduction represents an ecologically significant terminal electron acceptor for the mineralization of organic carbon. For example, in Mono Lake, California where the dissolved inorganic arsenic concentration is $0.2 \mathrm{mM}$, dissimilatory $\mathrm{As}(\mathrm{V})$ reduction can mineralize $8-14 \%$ of annual primary production by phytoplankton (Oremland et al., 2000).

It was in alkaline $(\mathrm{pH}=9.8)$, hypersaline Mono Lake that another aspect of microbial redox cycling of arsenic was recently discovered, namely the anaerobic oxidation of As(III) with nitrate or Fe(III) as oxidants (Hoeft and others, 2002). A Gram negative bacterium, strain MLHE-1, was isolated from lake water that demonstrated chemoautotrophic growth with As(III) as its electron donor according to the equation:

$\mathrm{H}_{2} \mathrm{AsO}_{3}{ }^{-}+\mathrm{NO}_{3}^{-} \rightarrow \mathrm{H}_{2} \mathrm{AsO}_{4}{ }^{-}+\mathrm{NO}_{2}^{-} \quad \Delta \mathrm{G}_{\mathrm{o}}{ }^{\prime}=-87.16 \mathrm{~kJ} / \mathrm{mole}$ (Oremland and others, 2002).

Microbiologically-linked oxidation of As(III) with nitrate has also been inferred to occur in Upper Mystic Lake, MA, an As-contaminated freshwater lake (D. Senn and H. Hemond, personal communication). Therefore, this process is not confined to just soda lakes, but is likely to be widespread in nature. When taken together with the aerobic chemoautotrophic oxidation of As(III) by strain NT-26 (Santini and others, 2000), it is clear that some microorganisms can also conserve energy for growth by oxidizing As(III) with stronger oxidants, like Fe(III), nitrate, or oxygen. This process is likely to be of importance in retarding the mobility of arsenic in subsurface aquifers that are poor in organics, but have abundant oxygen or nitrate to serve as oxidants. In addition, it is possible that oxygen- or nitrate-linked oxidation of As(III) by these microbes can be a mechanism by which arsenopyrite minerals in rocks ultimately undergo dissolution. 
Figure 1: Dissimilatory reduction of arsenate and selenate amongst the taxonomic domains of Bacteria and Archaea. Prokaryotes that respire arsenate are shown as black dots, selenium oxyanions as white dots, and microbes that can achieve respiratory growth with oxyanions of both elements as gray dots. This property occurs in both Gram + and diverse Gram - species, as well as in the Crenoachaeota. Since this tree was constructed in June, 2001, several new species have been described in literature that are not included in the figure.

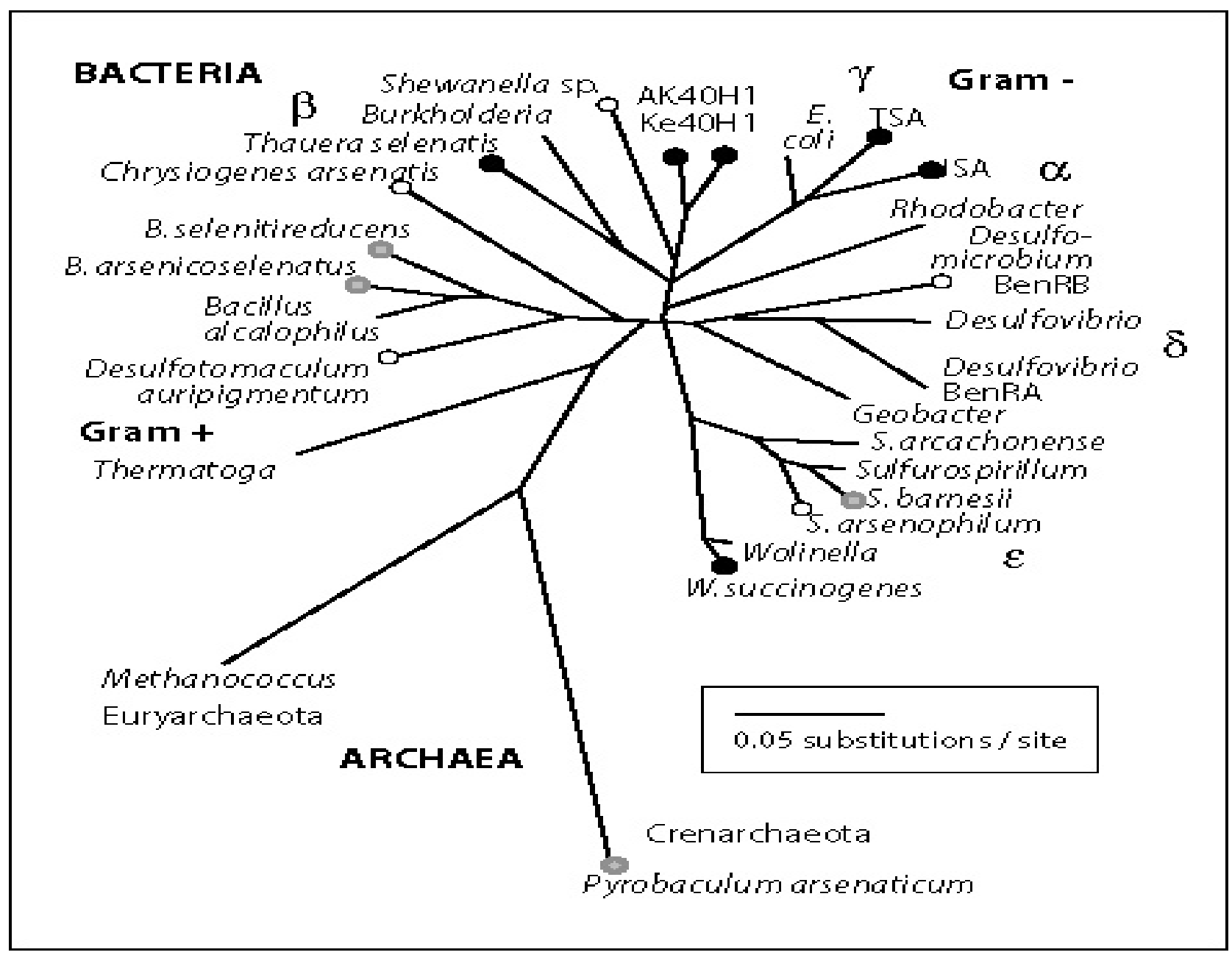

\section{References}

Hoeft, S.E. and others. 2002. Characterization of microbial arsenate reduction in the anoxic bottom waters of Mono Lake, California. Geomicrobiol. J. 19: $1-18$.

Newman, D.K., and others. 1998. A brief review of microbial arsenate respiration. Geomicrobiol. J. 15: 255 - 268.

Oremland, R.S., and others. 2002. Anaerobic oxidation of arsenite by a chemoautotrophic bacterium isolated from Mono Lake, California. Nature (in review).

Oremland, R.S. and others. 2001. Bacterial respiration of arsenate and its significance in the environment. In Environmental Chemistry of Arsenic (W.T. Frankenberger, Jr., ed.), p. 273 - 295, Marcel Dekker, N.Y. 
Oremland, R.S., and J.F. Stolz. 2000. Dissimilatory reduction of selenate and arsenate in nature. In Environmental Mtela-Microbe Interactions (D.R. Lovley, ed.), p. 199 - 224, ASM Press, Washington, D.C.

Oremland, R.S., and others.2000. Bacterial dissimilatory reduction of arsenate and sulfate in meromictic Mono Lake, California. Geochim. Cosmochim. Acta 64: 3073 - 3084.

Santini, J.M., and others. 2000. A new chemoautotrophic arsenite-oxidizng bacterium isolated from a gold mine: phylogenetic, physiological, and preliminary biochemical studies. Appl. Environ. Microbiol. 66: 92 - 97.

Stolz, J.F., and R.S. Oremland. 1999. Bacterial respiration of arsenic and selenium. FEMS Microbiol. Rev. 23: 615 627.

Zobrist, J. and others. 2000. Mobilization of arsenite by dissimilatory reduction of adsorbed arsenate. Environ. Sci. Technol. 34: 4747 - 4753. 


\title{
Planning for the Future of New York City's Water Supply System Using Artificial Recharge in the Coastal Plain Aquifers: A Cooperative Program between the USGS and the New York City Department of Environmental Protection
}

\author{
William A. Yulinsky, P.E., NYCDEP, Paul Misut, USGS, Donald K. Cohen, CPG, \\ Malcolm Pirnie, Inc.*
}

\begin{abstract}
The New York City Department of Environmental Protection (NYCDEP)and the US Geological Survey (USGS) have been cooperating on investigations into the use of the aquifers beneath Brooklyn and Queens as a supplemental potable water supply since the mid-1980's. Early cooperative efforts included application of the USGS Long Island-wide groundwater flow model to Brooklyn and Queens to evaluate the potential use of the aquifers. In the mid 1990's the USGS rediscretized the model in Brooklyn and Queens to further evaluate three specific pumping scenarios, including evaluation of natural and artificial recharge, as well as a preliminary evaluation of salt water intrusion under these scenarios. Concurrently, the NYCDEP evaluated the engineering requirements, cost estimates, and environmental impacts associated with the scenarios.
\end{abstract}

Currently, the USGS continues to cooperate with the NYCDEP in effort to develop an overall Groundwater Management Plan, which includes planning and testing of artificial recharge to the Lloyd and lower Magothy aquifers. The USGS has played a major role in characterizing the geologic controls and in developing the flow system analysis for this project. It will continue to be involved in ongoing field investigations designed to help confirm model assumptions and to further characterize and model the geochemistry of the Lloyd aquifer in particular. The USGS is also developing a more robust model to evaluate the long term movement of salt water under a variety of both transient and long term pumping scenarios, including artificial recharge and recovery of water from the Lloyd aquifer.

Planning activities for the Artificial Recharge project have identified several challenging issues. The Lloyd aquifer is the least studied of the Coastal Plain aquifers on Long Island, requiring significant assumptions in the flow system analysis. The location of the salt water-fresh water interface in the Lloyd aquifer is not known. Additional research is needed on the mineralogy of the Lloyd aquifer so that more specific geochemical modeling of source water-aquifer water interactions can be conducted. The planned use of potable water from the upstate surface water reservoirs of the New York City drinking water system as the source water poses challenges regarding changes in the chemistry of the groundwater during storage and subsequent recovery, and requires an evaluation of methods to condition the source water prior to recharge to prevent dissolution of iron and manganese from the aquifer matrix. The use of drinking water also raises significant permitting issues in New York related to the fate of disinfection byproducts (DBP's) in the aquifer. Low concentrations of DBP's, particularly chloroform, are present in the source water at levels that are well below drinking water standards, but above the New York State effluent standard for discharges to groundwater. However, the presence of chlorine residual in the source water should help impede the development of bacterial colonization and clogging of the wells. 


\title{
POSTER SESSION ABSTRACTS
}

\section{Correlations between Various Water-Quality Indicators of Recharged Recycled Water in Production Wells in Los Angeles County, California}

\author{
Robert Anders (randers@usgs.gov) and Roy A. Schroeder (raschroe@usgs.gov) \\ U.S. Geological Survey, 5735 Kearny Villa Road, Suite O, San Diego, CA 92123
}

\begin{abstract}
Water samples were collected from 23 production wells located within 500 feet (150 meters) of recharge basins in the Montebello Forebay in south-central Los Angeles County that receive local, imported, and reclaimed water; from an upgradient background well; and from effluent from a wastewater-treatment plant (recycled water). The water samples were analyzed for a broad suite of major and minor inorganic and dissolved organic constituents, nutrients, several isotopes, and selected microbial populations. These data were used to examine the relations (if any) that exist among various indicators of recycled water in the 23 production wells and the correlations between their concentrations and ground-water traveltimes and well depths.

Significant correlations exist between "excess" chloride (defined as the amount above the natural background level), "excess" boron, and nitrogen concentrations "calculated" (using nitrogen-isotope data) to the time of recharge, although all three methods overestimate recycled-water percentages in the production wells. There is a high correlation between dissolved organic carbon (DOC) and fluorescence (which results from fluorescent whitening agents), indicating little loss of DOC during recharge and subsequent travel to the production wells. Ethylenediaminetetraacetic acid and ultraviolet absorbance at 254 nanometers also are indicative of recycled water in the production wells.
\end{abstract}




\title{
Attenuation Rates for PRD-1 and MS2 During Recharge with Artificial Recharge with Recycled Water at a Research Basin in Los Angeles County
}

\author{
Robert Anders (randers@usgs.gov), ${ }^{1}$ William A. Yanko, ${ }^{2}$ Roy A. Schroeder \\ (raschroe@usgs.gov), ${ }^{1}$ and James L. Jackson ${ }^{2}$ \\ ${ }^{1}$ U.S. Geological Survey, 5735 Kearny Villa Road, Suite O, San Diego, CA 92123 \\ ${ }^{2}$ County Sanitation Districts of Los Angeles County, 1965 Workman Mill Road, Whittier, CA 90601
}

\begin{abstract}
Recharge experiments with recycled water conducted at a small research basin constructed adjacent to a large recharge facility in the Montebello Forebay of Los Angeles County, California indicated that bacteria can move through the soil with the percolating recycled water. These conclusions formed the basis for two field-scale tracer experiments using bacterial viruses (bacteriophage) PRD-1 and MS2 as surrogates for human viruses and bromide as a conservative tracer, to estimate virus attenuation rates under actual recharge conditions. Extensive data on the ratios of bacteriophage to bromide during the second experiment were obtained for samples collected from the research basin itself and from depths of $1,2,3,5$, and $10 \mathrm{ft}$ below the floor of the research basin. Regression analysis of the ratios collected during the 9-day experiment indicated an attenuation rate for MS2 of approximately $1.1 \log$ units over $10 \mathrm{ft}$, and an attenuation rate for PRD-1 of approximately $1.7 \log$ units over $10 \mathrm{ft}$. Using the observed attenuation rates, extrapolation suggests that a 7-log removal of bacteriophage should occur within less than $100 \mathrm{ft}$ of travel through the subsurface.
\end{abstract}




\title{
Using Environmental Tracers to Determine Long-Term Effects of Recharging Recycled Water in the Central Ground-Water Basin, Los Angeles County, California
}

\author{
Robert Anders (randers@usgs.gov) and Roy A. Schroeder (raschroe@usgs.gov) \\ U.S. Geological Survey, 5735 Kearny Villa Road, Suite O, San Diego, CA 92123
}

\begin{abstract}
Chlorofluorocarbons (CFCs), tritium-helium, chloride, boron, dissolved gases, and nitrogen isotopes were evaluated to determine some long-term effects of augmenting aquifer recharge using recycled water (secondary- and tertiary-treated wastewater). The USGS collected water and gas samples from four multiple-well monitoring sites located in Los Angeles County, California, along a flowpath extending from the Montebello Forebay in the north, where water is applied to large spreading basins, to the Central Ground Water Basin in the south. Recycled water has been used to replenish the underlying aquifers since the early 1960s.

CFCs and tritium-helium were used to date ground water with ages less than 50 years, and chloride and boron were used as tracers to locate the spatial distribution of recycled water along the flowpath. Based on tritiumhelium age determinations, ground-water samples ranged from less than 2 to more than 50 years. Although CFCs could not be used to determine ground-water ages, they proved to be sensitive tracers for the early period of recharge with recycled water. Using tritium-helium age determinations, in conjunction with measured CFC concentrations, researchers found that CFC concentrations are markedly elevated above atmosphere-water equilibrium in ground water older than about 20 years but still young enough to contain recycled water. Chloride and boron concentrations are generally highest in the youngest ground water (tritium-helium age determinations).

Analysis of dissolved gases show that the redox state of the ground-water basin has changed in response to recharge using recycled water. Dissolved-gases had higher concentrations of excess air in parts of the ground-water basin where recycled water is present. Also, these areas have no detectable methane, whereas methane is present in the native ground water older than 50 years. Some of the excess air probably originates as air trapped by rapid infiltration at the spreading grounds, but part has been identified as dissolved nitrogen resulting from denitrification.
\end{abstract}




\title{
Heat as a tracer for examining enhanced recharge processes along the Russian River, CA
}

\author{
By James E. Constantz (jconstan@usgs.gov) \\ U.S. Geological Survey, 345 Middlefield Road, Menlo Park, California 94025
}

\begin{abstract}
Ground water adjacent to the Russian River in Sonoma County, CA, is the primary source of drinking water pumped to Sonoma County Water Agency (SCWA) treatment facilities. This ground-water resource is superior to direct surface-water options, because experience has demonstrated that water extracted from the alluvial aquifer requires substantially less treatment than water extracted directly from the river, tributaries, or reservoirs. From late spring to early winter, SCWA erects an inflatable dam to raise the river stage and passively recharge the alluvial aquifer. The raised stage permits diversion of river water to a series of recharge ponds located upstream of the dam along the river. This results in enhanced extraction efficiency from water-supply wells situated along this reach of river. Production from these wells typically is reduced by $75 \%$ when the dam and recharge ponds are out of operation. Emerging issues, including fish habitat concerns and optimization of water resources management, indicate that a quantitative model should be developed to accurately represent river/ground-water exchanges in the region of the watershed encompassing the inflatable dam. Improved scheduling of dam and recharge pond operations, as well as supply well pumping patterns would be aided by the development of a proven ground-water model for this region of the watershed. Successful development of a model requires that key hydraulic parameters be identified, including the spatial and temporal pattern of river conductance. Several tools are available to estimate these hydraulic parameters, such as pumping tests and chemical tracers. Some pumping tests have been performed; however, introduced chemical tracers are not an option for the Russian River, due to environmental and esthetic concerns.
\end{abstract}

As an alternative to chemical tracers, the natural variation in river temperature affords the opportunity to use heat as a tracer of stream/ground-water exchanges in this reach of the Russian River. Earlier work successfully used heat as a tracer of ground-water recharge at various locations throughout the USA. Along the eastern seaboard, Lapham [1989] used annual temperature records from deep observation wells to identify rates of vertical water flux in several streams, based on analytical solutions reported in earlier work [Lapham, 1988]. In the Rio Grande near Albuquerque, NM, Bartolino and Niswonger [1999 ] used a similar approach with a USGS ground-water model, VS2DH, [Healy and Ronan, 1996]. They matched simulated temperature to observed temperature, yielding predicted estimates of deep streambed fluxes and spatial-averaged hydraulic conductivities. Thomas et al. [2000] used the same model to demonstrate that diurnal temperature patterns in shallow sediment could be successful in identifying shallower streambed conductance values at several locations along a reach of the Santa Fe River, NM.

For the Russian River, approximately 25 observation wells were instrumented for water-levels and groundwater temperatures, to compare with river stage and surface-water temperatures. Observed temperatures are being used to optimize simulated temperature from VS2DH, to predict the hydraulic conductivity at specific locations along this reach of the river. Early results identify a gradual decline of the streambed hydraulic conductivity upstream of the dam over the summer, which is probably due to accumulation of sediment.

The use of heat as a tracer to estimate percolation rates is also ongoing at the recharge pond facility in the vicinity of the inflatable dam. Again it is undesirable to use chemical tracers in this setting, so that natural variations in pond temperature should afford the opportunity to examine recharge characteristics. Earlier work by Nightingale [ 1975] and Constantz et al. [1999] suggests that heat could potentially be an excellent indication of recharge rates. Simulation results demonstrate that shallow temperature monitoring is useful for ponds operated in a low-stage mode, where diurnal temperature signals could be expected to be significant. For recharge ponds with greater stages, deeper sediment temperature monitoring is necessary to capture the annual temperature signal.

The recharge ponds near the Russian River are operated with a stage of only 0.4 to $0.8 \mathrm{~m}$, indicating that shallower sediments temperature should be monitored for diurnal analysis of heat and water transport beneath this facility. An intriguing thermal dissimilarity was observed for passive recharge from the river compared with the 
artificial recharge from the ponds. The use of heat as a tracer requires a accurate estimate of the upper thermal boundary condition. Observations on the Russian River have demonstrated that for virtually identical micrometeorological conditions, the sediment temperature profiles beneath the river are distinctly different than those beneath a standing body of water. For the river, water temperature and the surface-sediment temperature are comparable; however, this is not the case for shallow recharge ponds. During daylight, sediment surfaces have been observed to be several degrees greater than the standing water column in the recharge ponds, because solar energy is absorbed at a rate faster than its removal rate. Temperature equipment was installed below Recharge Pond \#3 at depths between the surface and $1.5 \mathrm{~m}$ and logged on a 30 minute frequency. This data is being used to estimate temporal patterns of percolation beneath the recharge basin on a daily basis. Observed temperatures show an increasing thermal gradient between the surface sediments and sediments at depth, over the duration of each recharge period. Increased vertical gradient indicates reduced advection of heat to deeper sediments, as a result of reduced recharge rates. Monitoring of this type of thermal information can be utilized to schedule surface-water routing during ponding and drying cycles for the recharge ponds.

Recently, a study was initiated to compare sediment-temperature-based measurements of seepage loss with surface-water-based estimates. In both the river and the recharge facility, shallow temperature profiles are compared to seepage measurements, derived from seepage meters temporary installations near temperature equipment. Initial comparisons of temperature-based and seepage-meter-based percolation rates are very encouraging, with good agreement for both the river sites and Recharge Pond \#3. In the future, continuous monitoring of ground-watertemperatures may lead to the capability to examine real-time trends in hydraulic clogging caused by sedimentation, and thus the ability to monitor real-time changes in ground-water recharge. Finally, this type of spatial and temporal parameter characterization will be useful in the planned construction of a MODFLOW model for this region of the Russian River, which is intended to evaluate the effects of various future scenarios on the water resources of Sonoma County.

\section{References}

Bartolino, J.R., and R. Niswonger, Numerical simulations of vertical ground-water fluxes of the Rio Grande from ground-water temperature profiles, Central New Mexico, U.S. Geological Survey, Water Resour. Invest. Rep. 99-42-12, pp.34, 1999.

Constantz, J., R. Niswonger, and A.E. Stewart, 1999, The use of heat as a tracer to estimate recharge beneath streams and artificial recharge ponds, in (ed.) R.D. Bartlett, Artificial Recharge of Groundwater, Amer. Soc. Civil. Engin., 193-203.

Healy, R.W., and A.D. Ronan, 1996. Documentation of computer program VS2DH for simulation of energy transport in variably saturated porous media, U.S. Geological Survey Water Resour. Invest. Rep. 96-4230, 36pp.

Lapham, W.W., Conductive and Convective Heat Transfer Near Stream, Ph.D. Dissertation, University of Arizona, Tucson, Arizona, pp. 315, 1988.

Lapham, W.W., Use of temperature profiles beneath streams to determine rates of vertical ground-water flow and vertical hydraulic conductivity , U.S. Geol. Surv. Water Supply Pap. 2337, 35ppp. 1989.

Nightingale, H.I., 1975. Groundwater recharge rates from thermometry, Ground Water, vol. 18(4), 340-344.

Thomas, C.L., A.E. Stewart, and J. Constantz, 2000, Comparison of methods to determine infiltration and percolation rates along a reach of the Santa Fe River near La Bajada, New Mexico, U.S.G.S. Water Resour. Invest. Rep. 00-4141, pp.31. 


\title{
Nitrate contamination and incorporation of excess air associated with artificial recharge in a desert basin, Yucca Valley, California
}

\author{
By Jill N. Densmore ${ }^{1}$ (densmore@usgs.gov), and J.K. Böhlke² (jkbohlke@usgs.gov) \\ ${ }^{1}$ U.S. Geological Survey, 624-B West Foster Road, Santa Maria, California \\ ${ }^{2}$ U.S. Geological Survey, 12201 Sunrise Valley Drive, Reston, Virginia 20192
}

\begin{abstract}
Historically, ground water has been the the sole source of water supply for the town of Yucca Valley in the Mojave Desert of southern California and, due to pumping, ground-water levels have declined as much as 300 feet since the 1950's (fig. 1). To reverse declines and to ensure future water needs are met, in 1995, the Hi-Desert Water District began recharging the basin using water imported from northern California. Subsequently, water levels rose as much as 240 feet (1999), and nitrate concentrations increased, in some cases, exceeding maximum contaminant levels established by the U.S. Environmental Protection Agency. The high nitrate content water also contains large quantities of dissolved gas, which when out-gassed in the delivery system, causes cloudy water and air accumulation within pipes.
\end{abstract}

In 1993, two multiple-completion monitoring sites (YV1 and YV2) were drilled near two artificial recharge ponds in the center of the basin. These sites were designed to monitor rising ground-water levels expected from the artificial recharge. In addition, water-quality samples were collected from these sites and from other existing well sites prior to, during, and after recharge to monitor changes in ground-water quality. The water samples were analyzed for major ions, nutrients, selected trace elements, and stable isotopes of hydrogen and oxygen $\left(\delta^{2} \mathrm{H}\right.$ and $\left.\delta^{18} \mathrm{O}\right)$. Selected ground-water samples were analyzed for nitrogen isotopes $\left(\delta^{15} \mathrm{~N}\right)$ to determine the source of increased nitrate, and for dissolved gases (nitrogen, argon, carbon dioxide, and oxygen) to determine the source of excess gas and to evaluate the possibility of denitrification resulting in an increase in the concentration of dissolved $\mathrm{N}_{2}$.

Nitrate concentrations in production well 17E (perforated from 450 to $800 \mathrm{ft}$ below land surface and located near the west recharge pond) have increased from $20 \mathrm{mg} / \mathrm{L}$ as nitrate $\left(\mathrm{NO}_{3}\right)$ in 1995 to $82 \mathrm{mg} / \mathrm{L}$ in 1999 . In contrast, during this same period, nitrate concentrations in an adjacent deeper well (16E, perforated from 920 to $1,450 \mathrm{ft}$ below land surface) have remained constant at $10 \mathrm{mg} / \mathrm{L}$ as $\mathrm{NO}_{3}$ and represent background levels. The nitrate concentration in well 17E, in January 1995, which was already higher than background levels, suggests that nitrate from surficial sources may have reached the shallow wells in some parts of the basin before recharge of imported water began. Because the nitrate concentration of imported water is low $(0.6 \mathrm{mg} / \mathrm{L})$, it is not likely the source of high nitrate concentrations in wells near the percolation ponds. $\delta^{15} \mathrm{~N}$ values indicate that the high nitrate concentrations in wells near the ponds could result in part, from septic-tank seepage in the unsaturated zone. In Yucca Valley, wastewater from homes and businesses is disposed of in septic tanks.

Dissolved nitrogen $\left(\mathrm{N}_{2}\right)$ gas concentrations ranged from 19 to $51 \mathrm{mg} / \mathrm{L}$, argon (Ar) concentrations ranged from 0.6 to $1.3 \mathrm{mg} / \mathrm{L}$, and oxygen $\left(\mathrm{O}_{2}\right)$ concentrations ranged from 6 to $19 \mathrm{mg} / \mathrm{L}$; some of these greatly exceed airsaturation values. The large variations in dissolved gas concentrations indicate that varying amounts of excess air were trapped in the water during artificial recharge through a thick unsaturated zone [more than 300 feet in 1995 (prior to artificial recharge)] and at least partly dissolved below the water table. Samples with the highest dissolved gas concentrations (from production wells $7 \mathrm{E}$ and 12E, which are adjacent to the west pond) had almost twice the concentrations of $\mathrm{Ar}$ and $\mathrm{N}_{2}$ expected from air-water equilibrium, equivalent to about 25-30 ccSTP/L of excess air. Other samples having high gas concentrations were from production wells 14E and 17E (near the east and west ponds, respectively, had about 17-20 ccSTP/L of excess air) and from YV1-305' and YV1- 230' (adjacent to the east pond had about 6-10 ccSTP/L of excess air). In contrast, the samples from production wells $9 \mathrm{~W}$ and $8 \mathrm{~W}$, in the western part of the basin had the equivalent of about 3-6 ccSTP/L of excess air, with apparent recharge equilibration temperatures of $10-13^{\circ} \mathrm{C}$. These samples are from outside the area of artificial recharge and the values are more typical of the natural recharge process. 
This study indicates unanticipated water-quality problems have resulted from artificial recharge efforts in Yucca Valley. It is proposed that increases in nitrate concentrations are due to the interception of downward-moving septic seepage by the rising water table and perhaps from the incorporation of natural pore-water nitrate from the unsaturated zone. In addition, large amounts of excess air were incorporated in the ground water due to artificial recharge through a thick unsaturated zone, resulting in undesired out-gassing in the delivery system causing cloudy water, air accumulation within pipes, and customer complaints.

Figure 1. Location of study area

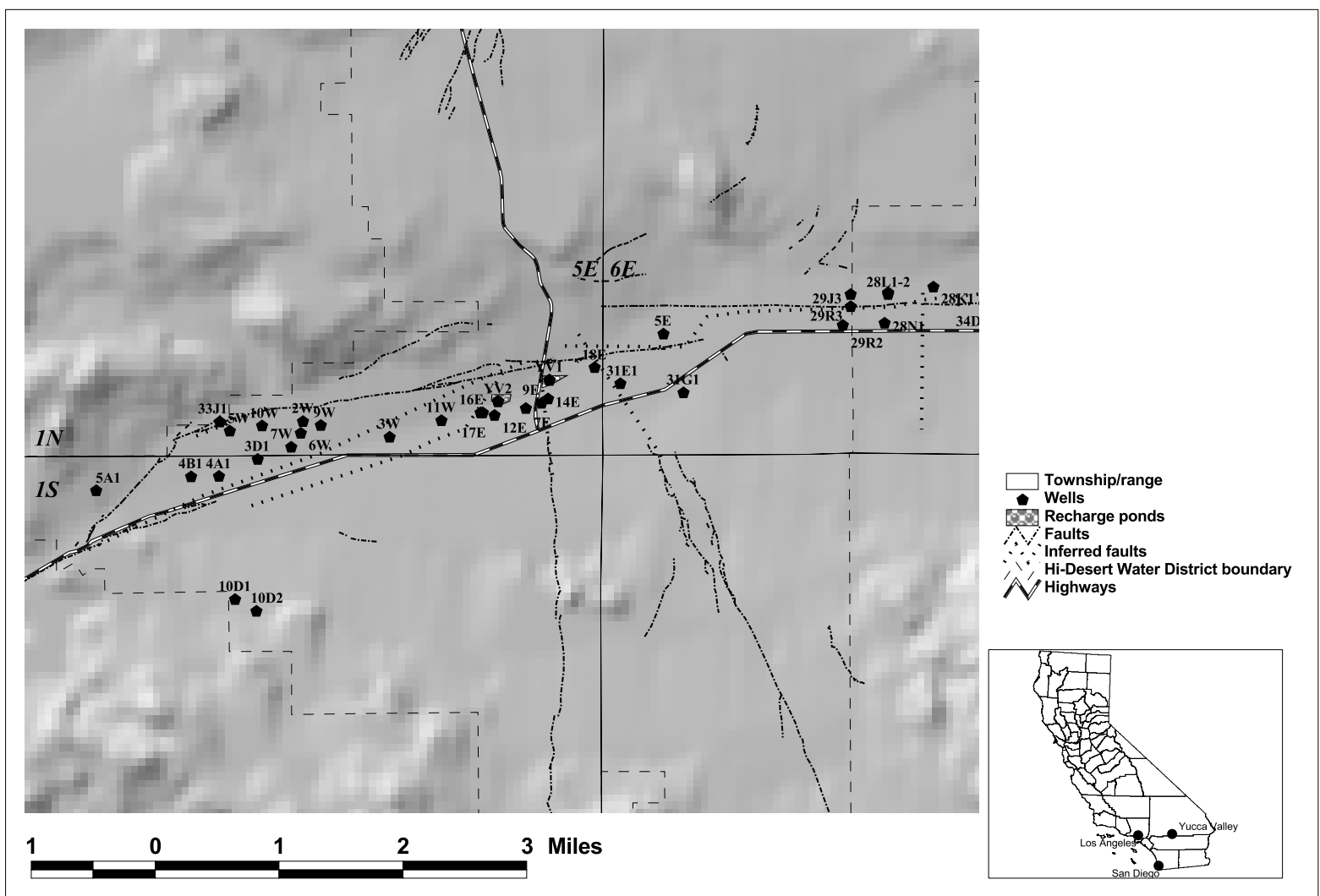




\title{
Processes Affecting the Trihalomethane Concentrations Associated with the Injection, Storage, and Recovery Tests at Lancaster, Antelope Valley, California
}

\author{
By Miranda S. Fram¹ (mfram@usgs.gov), Roger Fujii ${ }^{1}$ (rfujii@usgs.gov), Brian A. \\ Bergamaschi ${ }^{1}$ (bbergama@usgs.gov), Kelly D. Goodwin² (Kelly.Goodwin@noaa.gov), \\ and Jordan F. Clark ${ }^{3}$ (clark@geol.ucsb.edu) \\ ${ }^{1}$ U.S. Geological Survey, 6000 J Street, Placer Hall, Sacramento, California 95819-6129 \\ ${ }^{2}$ Cooperative Institute of Marine and Atmospheric Chemistry, 4301 Rickenbacker Cswy., Miami, Florida \\ 33149 \\ ${ }^{3}$ University of California, Santa Barbara, Department of Geological Sciences, Webb Hall, Santa Barbara, \\ California 92106
}

\begin{abstract}
The U.S. Geological Survey, in cooperation with the Antelope Valley-East Kern Water Agency and the Los Angeles County Department of Public Works, investigated the formation and fate of trihalomethanes (THM) during the 1998-1999 cycle of the subsurface injection, storage, and recovery program in Lancaster, Antelope Valley, California. This investigation was part of a larger project to assess the long-term feasibility of using subsurface injection, storage, and recovery as a water-supply method in the Antelope Valley. THMs $\left(\mathrm{CHCl}_{3}, \mathrm{CHCl}_{2} \mathrm{Br}\right.$, $\mathrm{CHClBr}_{2}$, and $\mathrm{CHBr}_{3}$ ) are disinfection by-products formed by reaction between natural dissolved organic carbon that is present in water and chlorine that is added during the drinking water treatment process (the water was chlorinated prior to injection into the aquifer). THMs are carcinogenic compounds and their concentrations in drinking water are regulated by the U.S. Environmental Protection Agency. During previous cycles of the Lancaster program, recovered water still contained measurable levels of THMs long after continuous pumping had extracted a greater volume of water than had been injected during the injection period of the cycle. This observation raised concerns about the potential long-term deleterious effect of subsurface injection, storage, and recovery cycles on ground-water quality in Antelope Valley aquifers. The primary objectives of our investigation were to 1) explain the variations in THM concentrations observed during the injection and recovery periods of a cycle, 2) determine the potential for natural attenuation of THMs in the aquifer, and 3) determine what caused the continued presence of THMs in the extracted water, even after long periods of pumping.
\end{abstract}

Our investigation included water-quality monitoring at the well used for injection and recovery and at a nearby set of piezometers; addition of the conservative tracer sulfur hexafluoride $\left(\mathrm{SF}_{6}\right)$ to the injection water; and laboratory experiments on biodegradation of THMs in microcosms of aquifer material, adsorption of THMs to aquifer sediments, and formation of THMs from the injection water. Aquifer bacteria were unable to degrade THMs under the aerobic conditions present in the aquifer. Degradation of $\mathrm{CHBr}_{3}$ did occur under anaerobic conditions in the laboratory. However, the aquifer is naturally aerobic and $\mathrm{CHCl}_{3}$ is the dominant $\mathrm{THM}$ species; therefore, anaerobic biodegradation is not considered an important attenuation mechanism for THMs in this aquifer. THMs did not adsorb significantly to the alluvial-fan sediments comprising the aquifer, thus, adsorption also is not considered an attenuation mechanism for THMs. Continued THM formation in the injection water after injection into the aquifer was limited by the amount of residual chlorine in the injection water at the time of injection. After accounting for THMs formed by consumption of the residual chlorine, THMs behaved as conservative constituents in the aquifer, and the only process affecting the concentration of THMs was mixing between the injected water and ground water present in the aquifer before the cycle.

The mixing process was quantified using mass balances of injected constituents, the $\mathrm{SF}_{6}$ tracer, and a simple, descriptive mathematical mixing model. Mass balance calculations show that only 60 percent of the injected THMs and chloride were recovered after a volume equivalent to 132 percent of the injection water volume had been extracted. Continued extraction of water to 250 percent of the injected volume only increased recovery of injected THMs to 72 percent. THM and $\mathrm{SF}_{6}$ concentrations in the extracted water decreased concomitantly during the recovery period, and THM concentrations predicted from $\mathrm{SF}_{6}$ tracer concentrations closely match the measured THM concentrations. Because $\mathrm{SF}_{6}$ initially was only present in the injection water, decreases in $\mathrm{SF}_{6}$ and $\mathrm{THM}$ 
concentrations must be due to dilution with ground water. The mixing model described mixing during the extraction period between the injected water and an equivalent volume of ground water that had been displaced by the injected water. This simple mixing model adequately predicts the concentrations of conservative constituents $\left(\mathrm{SF}_{6}, \mathrm{THMs}_{\mathrm{S}}\right.$ and chloride), and the temperature of the extracted water during the extraction period, providing further evidence to support the conclusion that mixing between injected water and ground water in the aquifer was the primary process controlling the concentration of THMs in the extracted water.

Modeling results and water-quality data both suggest that subsurface injection, storage, and recovery cycles will have a long-term impact on aquifer water-quality. The three nested piezometers were located in a borehole 80 horizontal feet from the injection/extraction well at depths corresponding to the middle and upper portion of the perforation interval in the injection/extraction well. THM concentrations in water from the nested piezometers remained high and variable throughout the recovery period, indicating that some of the injected water may become stranded in the aquifer, and that ground-water flow paths during the injection and extraction periods of the cycle may be different. The mixing model was used to forecast the results of repetitive annual cycles. Using realistic ratios of the volumes of injected and extracted water, the model forecasted that the concentration of THMs (or any conservative constituent from the injected water) in the vicinity of the injection/extraction well would reach nearly 100 percent of the concentration in the injected water in 10 years. This increase in concentration in water in the immediate vicinity of the injection/extraction well would be less if ground water from outside the region directly affected by injection also became involved in the mixing process. Finally, the model results indicated that extraction of all injected constituents would be essentially impossible because the volume of water that must be extracted increases exponentially as the desired concentration in the water remaining in the aquifer decreases. We conclude that low concentrations of THMs were measured in the extracted water even as the extracted volume of water approached 250 percent of the injected volume because injected water was retained in the aquifer as a result of mixing with ground water. 


\title{
Permeability Reduction Caused by Trapped Gas: Field-Scale Observations and Quantification With a Dissolved-Gas Tracer During a Ponded Infiltration Experiment
}

\author{
By Victor M. Heilweil ${ }^{1}$ (heilweil@usgs.gov) and D. Kip Solomon ${ }^{2}$ \\ (solomon@mines.utah.edu) \\ ${ }^{1}$ U.S. Geological Survey, 2329 W. Orton Circle, Salt Lake City, Utah 84119 \\ ${ }^{2}$ University of Utah, School of Mines
}

\begin{abstract}
Laboratory studies and field-scale artificial recharge experiments have demonstrated reduced permeability caused by trapped gases. Initially, infiltration rates drop due to air entrapment, causing decreases in vertical hydraulic conductivity. Longer-term permeability reduction caused by bacterially generated gases also has been observed, which has implications for both ponded and injection-well artificial recharge projects.
\end{abstract}

A ponded infiltration experiment was monitored during a 10-month period to evaluate potential artificial ground-water recharge beneath the Sand Hollow Reservoir near St. George, Utah. As part of this experiment, dissolved helium was introduced to the pond, along with dissolved bromide, to act as a partitioning tracer. Because of its low-solubility in water, helium preferentially partitions to a gas phase when it encounters trapped gas bubbles. This produces a net retardation of helium relative to a non-partitioning (non-volatile) tracer such as bromide. Previously, such gas-phase partitioning tracers have only been used in laboratory-scale experiments. Because of the large degree of retardation, it was necessary to measure helium at very low concentrations (at C/Co down to 1E-5). Fortunately, this is possible by using mass spectrometric methods that measure helium isotope ratios. Also, the biological source of the trapped gases was confirmed by high concentrations of dissolved carbon dioxide, methane, and hydrogen measured in water samples from shallow depths beneath the pond.

The helium tracer breakthrough occurred as much as 5 months after the brom ide tracer (fig. 1). The retardation of the dissolved-helium tracer in comparison to the bromide tracer at various depths beneath the pond indicates that as much as 10 percent of the porosity of material beneath the pond was filled with gas. Theoretically, this gas would exist mostly in the larger pore-throats. Laboratory measurements of hydraulic conductivity at varying degrees of saturation indicate that a 10-percent air-filled porosity may reduce vertical hydraulic conductivity by as much as two orders of magnitude. Therefore, trapped gases may be the primary rate limiting parameter for artificial recharge at the site.

Net infiltration rates quickly dropped off after the first few days from about $0.4 \mathrm{ft} / \mathrm{d}$ to less than $0.2 \mathrm{ft} / \mathrm{d}$ (fig. 2). Infiltration rates varied over a narrow range of 0.13 to $0.18 \mathrm{ft} / \mathrm{d}$ from August through February, but increased during the last 2 months of the experiment (March and April) to more than $0.2 \mathrm{ft} / \mathrm{d}$. Much of the decrease in infiltration rates in the fall and increase in the spring was likely caused by changes in hydraulic conductivity caused by changes in the dynamic viscosity of water at different temperatures. 


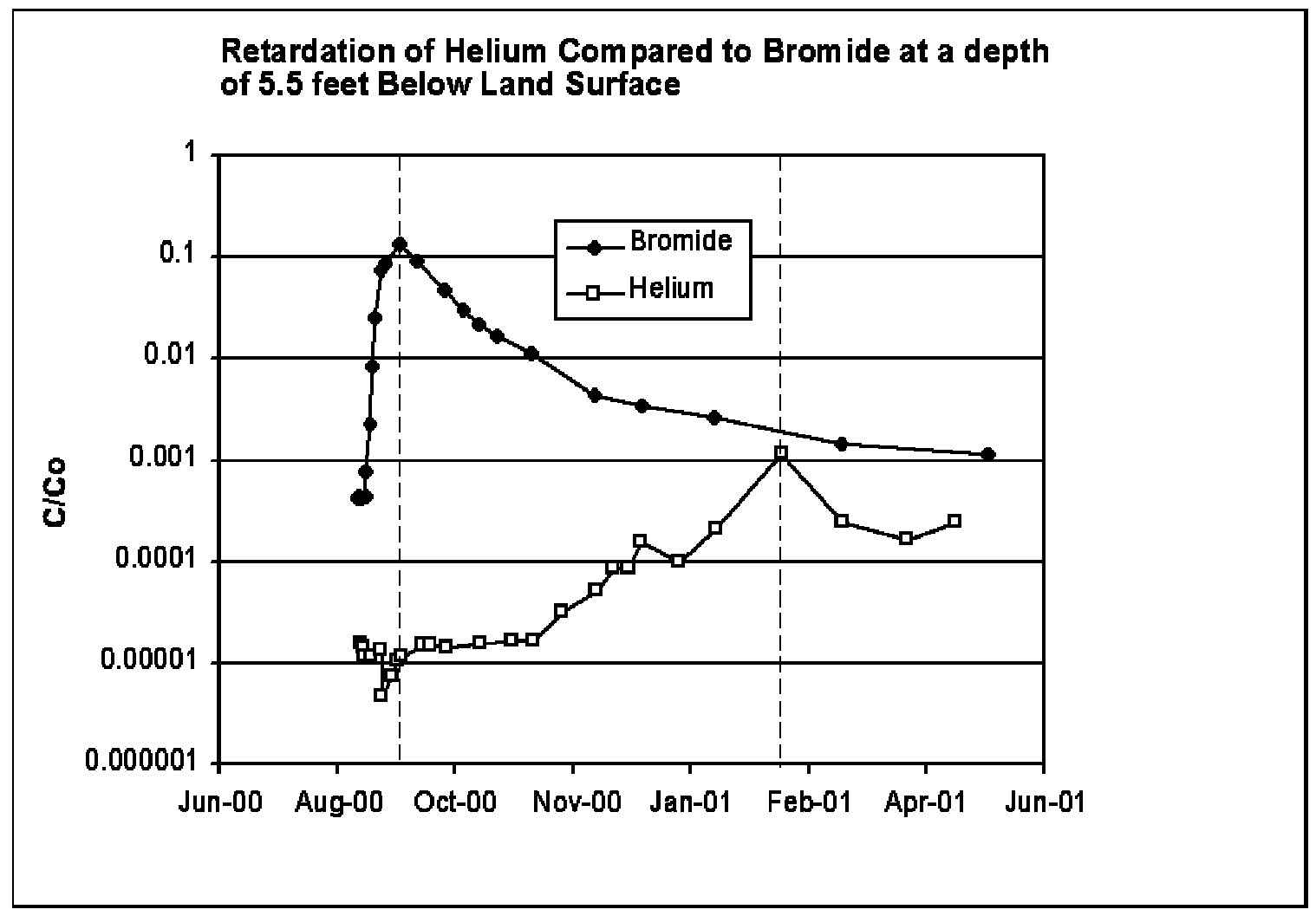

Figure 1. Retardation of breakthrough of dissolved helium compared to dissolved bromide at a depth of 5.5 feet below land surface during the infiltration pond experiment at Sand Hollow near St. George, Utah.

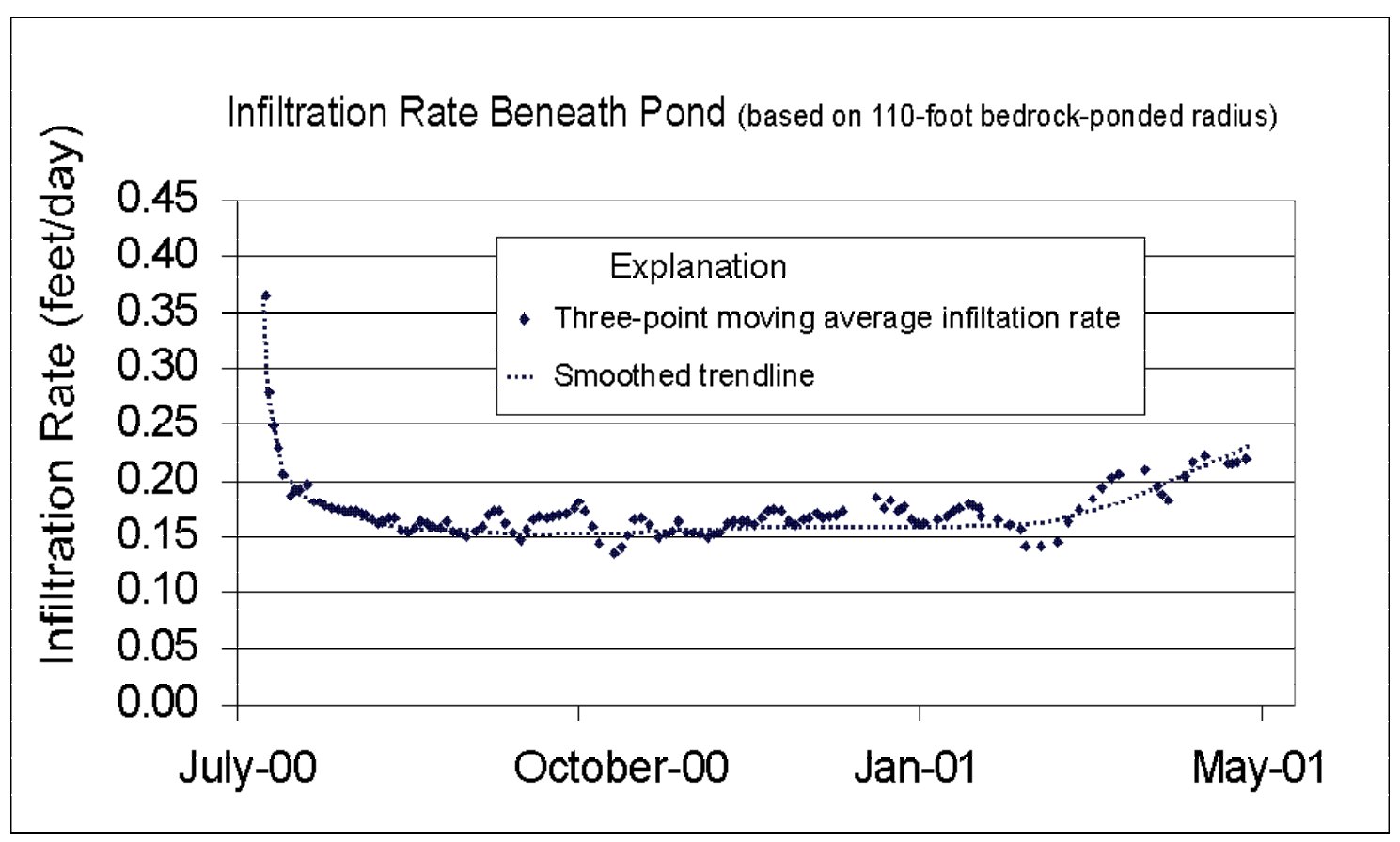

Figure 2. Infiltration rates during the 10-month infiltration pond experiment at Sand Hollow near St. George, Utah. 


\title{
Artificial Recharge through a Thick, Heterogeneous Unsaturated Zone near an Intermittent Stream in the Western Part of the Mojave Desert, California
}

\author{
By: John A. Izbicki (jaizbick@usgs.gov) and Christina L. Stamos (clstamos@usgs.gov) \\ U.S. Geological Survey, 5735 Kearny Villa Road, Suite O, San Diego, California 92123
}

\begin{abstract}
Population in the western part of the Mojave Desert, near Victorville, has increased from 90,000 in 1980 to more than 300,000 in 1999 (Ronald Rector, High Desert Economic Development Agency, oral communication, 1999). Ground-water pumping has increased with population resulting in declining water levels: artificial recharge may help mitigate the declines. The Victor Valley Water District is planning an experiment to test the feasibility of using surface spreading to artificially recharge the regional aquifer near the channel of Oro Grande Wash, about 90 miles northeast of Los Angeles. The regional aquifer is composed of alluvial deposits more than 1,000 feet thick that consist of partly consolidated sand, silt, and gravel weathered from the San Gabriel Mountains. Natural recharge is limited to the infiltration of stormflow in washes and averages about 10,700 acre-ft/yr (Stamos and others, 2001). In comparison, natural recharge to the floodplain aquifer along the Mojave River, also from infiltration of stormflows, averaged about 46,000 acre-ft/yr during 1995-99, and about 25,000 acre-ft/yr during 1931-90 (Stamos and others, 2001). Ground-water discharge, primarily from pumping, greatly exceeded recharge in the area, and averaged about 74,000 acre-ft between 1995 and 1999 (Stamos and others, 2001). Due to the disparity between pumping and recharge, water levels in this area of the regional aquifer have declined more than $1 \mathrm{ft} / \mathrm{yr}$ between 1995 and 2000 (Stamos and others, 2001) and water rights in the basin have been the subject of recent adjudication.
\end{abstract}

Artificial recharge will be by infiltration of water from a pond located near the channel of Oro Grande Wash, an intermittent stream that flows for brief periods after storms. The site was selected because it is near public supply wells, small only amounts of natural recharge occur in the wash, and thick, impermeable caliche deposits that underlie much of the area are not present beneath the wash (Izbicki and others, 2000). In addition, highly permeable sand and gravels deposited by the ancestral Mojave River, are present near the water table beneath the proposed recharge site. The high permeability of these deposits will facilitate the recovery of recharged water by nearby wells. At this site, artificial recharge water must move to the water table through about a 430 -ft thick heterogeneous unsaturated zone.

Downward movement of recharge water will be measured at a highly instrumented borehole equipped with heat dissipation probes and advanced tensiometers used to measure changes in matric potential in the unsaturated zone, and a pressure transducer that measures changes in water table levels in the water-table. The well also will serve as an access port for electromagnetic geophysical tools used to measure the movement of the recharge water between instruments. Samples collected from suction-cup lysimeters will monitor changes in the concentration of chloride, nitrate, arsenic, chromium, and other constituents as recharge water infiltrates through the thick unsaturated zone beneath the site. Heat dissipation probes, advanced tensiometers and pressure transducers will be linked to the web for remote monitoring during the recharge experiment.

A calibrated ground-water flow model developed by the U.S. Geological Survey (Stamos and others, 2001) was used to simulate effects of artificial recharge at selected sites during a simulated 20-year drought. Model simulations show that if 8,000 acre-ft of artificial recharge is applied annually for the 20-year period at existing facilities located in the floodplain aquifer along the Mojave River (10 mi to the east) the water-level may rise rise less than $10 \mathrm{ft}$ in the regional aquifer beneath the study site. In contrast, if 2,000 acre-feet of artificial recharge is applied annually over the same 20-year period at the site in Oro Grande Wash, water levels may rise as much as 30 $\mathrm{ft}$ in the regional aquifer beneath the site; if 8,000 acre- $\mathrm{ft}$ of water is applied annually water levels may rise as much as $90 \mathrm{ft}$. 


\section{References Cited}

Izbicki, J.A., Radyk, John, and Michel, R.L., 2000, Water movement through a thick unsaturated zone underlying an intermittent stream in the western Mojave Desert, southern California, USA. Journal of Hydrology, Vol. 238, pp. 194-217.

Stamos, C.L., Martin, Peter, Nishikawa, Tracy, and Cox, B.F., 2001, Simulation of ground-water flow in the Mojave River basin, California, U.S. Geological Survey Water-Resources Investigation Report 01-4002, 129 p. 


\title{
Simulation of the Effects of Reclaimed-Water Application in West Orange and Southeast Lake Counties, Florida
}

\author{
By Andrew M. O’Reilly (aoreilly@usgs.gov) \\ U.S. Geological Survey, 224 W. Central Parkway, Altamonte Springs, Florida 32714
}

\begin{abstract}
Wastewater reclamation and reuse has become increasingly popular as water agencies search for alternative water supply and wastewater disposal options. Several governmental agencies in central Florida currently use the land-based application of reclaimed water (wastewater that has been treated beyond secondary treatment) as a management alternative to surface-water disposal of wastewater. Water Conserv II, a water reuse project developed jointly by Orange County and the City of Orlando, began operation in December 1986. In 1995, the Water Conserv II facility distributed approximately $28 \mathrm{Mgal} / \mathrm{d}$ of reclaimed water for discharge to rapid infiltration basins (RIBs) and for use as agricultural irrigation. The Reedy Creek Improvement District (RCID) began operation of RIBs in September 1990, and in 1995 these RIBs received approximately $6.7 \mathrm{Mgal} / \mathrm{d}$ of reclaimed water. Analyses of existing data and data collected during the course of this study were combined with ground-water flow modeling and particle-tracking analyses to develop a process-oriented evaluation of the regional effects of reclaimed water applied by Water Conserv II and the RCID RIBs on the hydrology of west Orange and southeast Lake Counties.
\end{abstract}

The ground-water flow system beneath the study area is a multiaquifer system that consists of a thick sequence of highly permeable carbonate rocks overlain by unconsolidated sediments. The hydrogeologic units are the unconfined surficial aquifer system, the intermediate confining unit, and the confined Floridan aquifer system, which consists of two major permeable zones, the Upper and Lower Floridan aquifers, separated by the less permeable middle semiconfining unit. Flow in the surficial aquifer system is dominated regionally by diffuse downward leakage to the Floridan aquifer system and is affected locally by lateral flow systems produced by streams, lakes, and spatial variations in recharge. Ground water generally flows laterally through the Upper Floridan aquifer to the north and east. Many of the lakes in the study area have no stream inflow or outflow, because the mantled karst environment precludes a well developed network of surface-water drainage.

The USGS three-dimensional ground-water flow model MODFLOW was used to simulate ground-water flow in the surficial and Floridan aquifer systems. A steady-state calibration to average 1995 conditions was performed by using a parameter estimation program to vary values of surficial aquifer system hydraulic conductivity, intermediate confining unit leakance, and Upper Floridan aquifer transmissivity. The calibrated model generally produced simulated water levels in close agreement with measured water levels and was used to simulate the hydrologic effects of reclaimed water application under 1995 and proposed future conditions.

Based on historical data, increases of up to about $40 \mathrm{ft}$ in the water table and less than $5 \mathrm{ft}$ in the Upper Floridan aquifer potentiometric surface had occurred by 1995 as a result of reclaimed water application. The largest increases were under RIB sites. Model results generally agreed with these data. An average traveltime of 10 years at Water Conserv II and 7 years at the RCID RIBs was required for reclaimed water to move from the water table to the top of the Upper Floridan aquifer. Elevated chloride concentrations measured in Whittenhorse Creek and Perimeter Canal indicate that reclaimed water from the RCID RIB site probably is discharging to adjacent surfacewater features. Approximately 67 percent of the reclaimed water applied at the RCID RIB site recharged the Floridan aquifer system, whereas 33 percent discharged from the surficial aquifer system to surface-water features; 99 percent of the reclaimed water applied at Water Conserv II recharged the Floridan aquifer system, whereas only 1 percent discharged from the surficial aquifer system to surface-water features. At Water Conserv II, an unquantified amount of reclaimed water is lost to evapotranspiration at agricultural irrigation sites. The majority of reclaimed water applied at both facilities probably ultimately will discharge from the Floridan aquifer system outside the model boundaries.

Proposed future conditions were assumed to consist of an additional $5.9 \mathrm{Mgal} / \mathrm{d}$ of reclaimed water distributed by Water Conserv II to discharge to new RIBs and to irrigate the new Orange County National Golf Center, with an additional $5.8 \mathrm{Mgal} / \mathrm{d}$ of reclaimed water discharged to RCID RIBs. Increases of up to about $20 \mathrm{ft}$ in 
the water table and $2 \mathrm{ft}$ in the potentiometric surface of the Upper Floridan aquifer were simulated. The directions of reclaimed water movement through the ground-water system generally were similar to those under 1995 conditions. However, the greater reclaimed water application rate at the RCID RIBs caused approximately half of the RCID reclaimed water to discharge to surface-water features and half to recharge the Floridan aquifer system. 


\title{
Flow system analysis using a surface-applied tracer at the Idaho National Engineering and Environmental Laboratory, Idaho.
}

\author{
By Kim S. Perkins ${ }^{1}$, John R. Nimmo ${ }^{1}$, Peter A. Rose ${ }^{2}$, Joseph P. Rousseau ${ }^{2}$, Brennon \\ R. Orr ${ }^{2}$, Brian V. Twining ${ }^{2}$, and Steve R. Anderson ${ }^{3}$ \\ ${ }^{1}$ U.S. Geological Survey, 345 Middlefield Rd., Menlo Park, California 94025 \\ ${ }^{2} \mathrm{EGI}$, University of Utah, 423 Wakara Way, Suite 300, Salt Lake City, Utah 84108 \\ ${ }^{3}$ U.S. Geological Survey, P.O. Box 2230, Idaho Falls, Idaho 83401
}

\begin{abstract}
Diverse hydraulic processes control water flow through the 200-m-thick unsaturated zone at the Idaho National Engineering and Environmental Laboratory (INEEL) in southeastern Idaho. The interbedded basalts and sediments that comprise the subsurface are characterized by complex structure in terms both of preferential flow paths and of layers that contrast in thickness, permeability, porosity and other properties. Water movement in the unsaturated zone at this site may be predominantly vertical, but is likely to be significantly retarded and diverted by features of the basalts and sediments. The behavior and composition of perched water observed since the 1970s suggests that this water may sometimes move laterally or recharge the aquifer at unusually high flow rates and volumes. Several studies (Barraclough et al., 1976; Rightmire and Lewis, 1987; Anderson and Lewis, 1989) have shown that water episodically accumulates in perched layers that typically persist for a few months. By analysis of water levels and measured water content profiles, Cecil et al. (1991) showed that perching can take place within both sediments and basalts, and suggested that specific mechanisms for this might include (1) contrasts in vertical hydraulic conductivity between basalt flows and sedimentary interbeds, (2) reduced hydraulic conductivity in baked zones between basalt flows, (3) reduced vertical hydraulic conductivity in dense, unfractured basalt, and (4) reduced vertical hydraulic conductivity from sedimentary and chemical filling of fractures in basalt. Additionally, the interfaces between any adjacent layers, regardless of whether the upper or lower one is more permeable, may retard flow under unsaturated conditions (Miller and Gardner, 1962).
\end{abstract}

Large-scale flow in the unsaturated zone is commonly assumed to be slow (a few $\mathrm{m} / \mathrm{yr}$ or less) and predominantly vertical, especially in arid regions. Slow transport is likely if the flow proceeds in classic diffuse fashion, limited by low hydraulic conductivity. Vertical flow is likely if the main driving force is gravity, or if the subsurface in effect is areally homogeneous. The slow-flow generalization may not hold for circumstances that include such features as unusually thick or geologically diverse unsaturated zones; large, nonuniform inputs of water over the land surface; or layers of contrasting subsurface materials that are likely to inhibit vertical flow and therefore to promote horizontal flow. Preferential flow paths can transport water horizontally to adjacent regions or vertically to the aquifer far sooner than might be predicted based on average medium properties.

In this study, a conservative tracer was applied to artificial infiltration ponds at the INEEL in order to assess travel times to the aquifer and perched water zones. During seasonal periods of high flow, water is diverted from the Big Lost River to a series of ponds in the southwestern portion of the INEEL. At this semiarid location, seasonal streamflow, local runoff, and snowmelts episodically generate large quantities of infiltrating water for periods of days or weeks. The ponds used in this study are used typically for a few weeks every two to three years. During a high flow period, 675 kilograms of a conservative chemical tracer (1,5 naphthalene disulfonate) was applied to water in the infiltration ponds. Fifty-kg bags of tracer were distributed at the water surface over the bow of a pontoon-type power boat, allowing the material to gradually spill out and the propeller to disperse it as the boat moved forward. Water inflow to the ponds continued for 10 days after the introduction of tracer, during which the cumulative flow was about $10^{7} \mathrm{~m}^{3}$. Samples for tracer analysis were collected from nearby wells completed in the Snake River Plain aquifer and in perched water zones. A monitoring network of existing wells, both up- and downgradient, was selected to characterize the vertical and horizontal extent of infiltrated water. Each well was sampled using a dedicated pump or bailer following USGS protocol (Mann 1996).

The tracer used in this study has been successfully tested for tracing in geothermal systems, though not in ground-water applications. 1,5 naphthalene disulfonate is environmentally benign, easily detectable by ultravioletfluorescence spectroscopy, and thermally stable (Rose et al., 2001). The adsorption properties of the polyaromatic 
sulfonates have generally not been reported, however, under low-temperature geothermal conditions 1,5naphthalene disulfonate was shown not to adsorb (Rose et al., 1999). Because the sulfonate groups make these molecules very anionic, the polyaromatic sulfonates are not likely to adsorb on negatively charged rocks or sands. In addition, the sulfonate groups render these compounds nontoxic and very soluble in water.

The tracer was detected in the aquifer in one well $0.1 \mathrm{~km}$ from the nearest infiltration pond 9 days following tracer introduction, indicating average vertical movement of at least $22 \mathrm{~m} /$ day at that location. Tracer was detected in seven wells completed less than $80 \mathrm{~m}$ deep in perched water zones, two of them $0.1 \mathrm{~km}$ away, one $1.2 \mathrm{~km}$ away, and five $1.5 \mathrm{~km}$ away. These detections suggest an average horizontal flow rate of $13 \mathrm{~m} /$ day or more along at least two flow paths. The results also indicate that very discrete flow paths may exist in this environment.

This study has shown that 1,5 naphthalene disulfonate is stable and conservative in the subsurface to the degree necessary for large-scale saturated- and unsaturated-zone investigations. Our results indicate that fractured basalts allow fast, long-range flow through the unsaturated zone under high-water content conditions generated by ponded infiltration. With a large input of water, the overall geologic structure promoted rapid horizontal flow that persisted over distances greater than $1 \mathrm{~km}$, entirely within the unsaturated zone, $100 \mathrm{~m}$ and more above the aquifer. At least under ponded infiltration, fine-textured interbeds and layers of dense basalt did not prevent the rapid recharge through fractured basalt. However, some impediments to vertical flow were sufficiently effective to cause substantial perching and horizontal diversion of flow. Because rapid flow in the unsaturated zone seems to be caused by natural features responding to a common case of ponded infiltration, these results suggest that similar phenomena may occur at other sites where the unsaturated zone is geologically complex.

\section{References}

Anderson, S.R., and B.D. Lewis. 1989. Stratigraphy of the unsaturated zone at the radioactive waste management complex, Idaho National Engineering Laboratory, Idaho. Water Resources Investigations Report 89-4065 (DOE/ID-22080). U.S. Geological Survey.

Barraclough, J.T., J.B. Robertson, and V.J. Janzer. 1976. Hydrology of the solid waste burial ground as related to the potential migration of radionuclides, Idaho National Engineering Laboratory. Open-File Report 76-471. U.S. Geological Survey.

Cecil, L.D., B.R. Orr, T. Norton, and S.R. Anderson. 1991. Formation of perched ground-water zones and concentrations of selected chemical constituents in water, Idaho National Engineering Laboratory, Idaho 198688. Water-Resources Investigations Report 91-4166 (DOE/ ID-22100). U.S. Geological Survey.

Mann, L.J. 1996. Quality-assurance plan and field methods for quality-of-water activities, U.S. Geological Survey, Idaho National Engineering Laboratory, Idaho. Open-File Report 96-615. U.S. Geological Survey.

Miller, D.E., and W.H. Gardner. 1962. Water infiltration into stratified soil. Soil Sci. Soc. Amer. Proc. 26:115-119.

Rightmire, C.T., and B.D. Lewis. 1987. Hydrology and geochemistry of the unsaturated zone, radioactive waster management complex, Idaho National Engineering Laboratory, Idaho. Water Resources Investigations Report 87-4198. U.S. Geological Survey.

Rose, P.E., W.R. Benoit, and P.M. Kilbourn. 2001. The application of the polyaromatic sulfonates as tracers in geothermal reservoirs. Geothermics 30:[in press].

Rose, P.E., C. Goranson, D. Salls, and P.M. Kilbourn. 1999. Tracer testing at Steamboat Hills, Nevada, using fluorescein and 1,5-naphthalene disulfonate. In Proceedings, 24th Workshop on Geothermal Reservoir Engineering, Stanford University, SGP-TR-162. 


\title{
Aquifer Storage and Recovery in the Santee Limestone /Black Mingo Aquifer, Charleston, South Carolina, 1993-2001
}

\author{
By Matthew D. Petkewich ${ }^{1}$ (mdpetkew@usgs.gov), Kevin J. Conlon ${ }^{2}$ \\ (kjconlon@usgs.gov), June E. Mirecki ${ }^{3}$ (June.E.Mirecki@erdc.usace.army.mil), and \\ Bruce G. Campbell ${ }^{1}$ (bcampbel@usgs.gov) \\ ${ }_{1}^{1}$ U.S. Geological Survey, 720 Gracern Road, Columbia, South Carolina, 29210 \\ 2U.S. Geological Survey, 1815 Ion Street, Sullivans Island, South Carolina 29482 \\ ${ }^{3}$ U.S. Army Corps of Engineers Waterways Experiment Station, Vicksburg, Mississippi
}

\section{INTRODUCTION}

The primary source of potable water for the city of Charleston, South Carolina, is treated surface water from the Edisto and Back Rivers. Although the Charleston Commissioners of Public Works (CCPW) has a treatment capacity that far exceeds normal demand, there is concern that demand may exceed delivery capacity in the event of damage to the water-distribution system. For this reason, the CCPW, in conjunction with the U.S. Geological Survey (USGS), is evaluating the geochemical and hydrologic effects of an Aquifer Storage Recovery (ASR) system on the Charleston peninsula.

The feasibility of ASR technology to store potable water was tested at a pilot site located in Charleston, west of the Ashley River between 1993-95 (Campbell and others, 1997). During this pilot investigation (Phase I), nine successive cycles (injection, storage, recovery) were conducted to evaluate hydrologic and water-quality changes resulting from injection of treated water into the Santee Limestone/Black Mingo (SL/BM) aquifer, the northernmost equivalent of the Floridan aquifer system (Park, 1985).

Pilot study results showed that ASR implementation on the Charleston peninsula is feasible, with recovery of potable water that ranged between 38 and 61 percent of the total volume injected (Campbell and others, 1997). During the pilot project, storage typically was short, with durations less than 6 days. Significant questions, however, remained unanswered after completion of the pilot project involving 1) injectant water-quality changes during longterm storage, 2) changes in hydraulic properties of the SL/BM aquifer resulting from injection, and 3) the feasibility of ASR methods in the SL/BM aquifer on the Charleston peninsula, approximately 2 miles east of the pilot site.

Results from a second ASR investigation (Phase II), located in downtown Charleston, include water quality and hydraulic properties for four ASR cycles with 1-, 3-, and 6-month storage periods. The Phase II study defines the approximate percent of potable water that is retrievable with long-term storage in the SL/BM aquifer, and indicates how the mixing of the two water bodies affects the water quality of the recovery water. In addition, this study will evaluate geochemical processes during long-term storage and quantify any changes in the SL/BM aquifer properties in the Charleston area resulting from ASR implementation.

\section{PHASE II INVESTIGATION}

In 1998, a second ASR system was constructed on the Charleston peninsula to investigate changing hydraulic properties and water quality during long-term (1- to 6-month) storage of injected water. The second ASR site consists of a single production well $(\mathrm{CHN}-812)$ and three observation wells. The production well is equipped with a 4-inch injection line and a 25 -horsepower pump, is cased with ductile steel, and is screened at the same intervals as the observation wells. Observation wells CHN-809, CHN-810, and CHN-811 are installed at distances of 76,122 , and $487 \mathrm{ft}$, respectively, from the production well, specifically to facilitate aquifer hydraulic-property characterization and also to monitor injected water movement and water-quality changes occurring during ASR cycles. Two of the observation wells are instrumented with probes to measure water-quality properties within the permeable zones. Water-quality samples are obtained from the discharge line at the production well head, and also directly from the permeable zones in the observation wells. A piston-driven submersible pump and low-flow (micropurging) sampling techniques were used to ensure the collection of representative ground-water samples.

Each ASR cycle consists of an injection, storage, and recovery period. The length of the injection phase (and hence volume of injected water) is determined by the breakthrough of 'fresh' (low chloride concentration) water at the proximal observation well CHN-809. The SL/BM aquifer water consists of chloride concentration and 
specific conductance of about 2,000 milligrams per liter $(\mathrm{mg} / \mathrm{L})$ and 7,400 microsiemens per centimeter at 25 degrees Celsius $(\mu \mathrm{S} / \mathrm{cm}$ ), respectively. Treated drinking water, with chloride concentrations of $22 \mathrm{mg} / \mathrm{L}$ (specific conductance $=230 \mu \mathrm{S} / \mathrm{cm}$ ), is injected at an approximate rate of 11 gallons per minute (gal $/ \mathrm{min})$. Injection proceeds until the chloride concentration decreases below the U.S. Environmental Protection Agency (USEPA) National Drinking Water Standard, Secondary Maximum Contaminant Level (SMCL) for chloride ( $250 \mathrm{mg} / \mathrm{L}$ ) (U.S. Environmental Protection Agency, 1988) at well CHN-809. Breakthrough curves are defined using specific conductance trends measured by probes placed within the permeable zones, supplemented with water-quality data from ground-water samples collected weekly at depths of 370 and $430 \mathrm{ft}$ below land surface. The duration of storage is 1 month, 3 months, or 6 months, during which water-quality samples are collected intermittently from the observation wells. Injected water is recovered at a pumping rate of about $130 \mathrm{gal} / \mathrm{min}$. Recovery continues until samples show chloride concentrations and specific conductance values equal to pre-test conditions. Water-quality samples are collected biweekly from the observation wells and the production well head during the recovery stage.

\section{PRELIMINARY RESULTS}

As of December 2001, three complete ASR cycles (with 1- and 3-month storage periods) and all but the recovery phase of a 6-month storage cycle have been completed. During the second ASR cycle, specific conductance and chloride concentrations decreased more rapidly during breakthrough at well CHN-809 than the first ASR cycle (Petkewich and others, 2000). Injection during the third and fourth ASR cycles required the same amount of injecting time for the freshwater breakthrough as the second cycle. The decrease in breakthrough time observed for the second and subsequent ASR cycles may indicate that during the first cycle aquifer permeability was enhanced by mineral dissolution. This decreased travel time also was observed during the pilot ASR project (Mirecki and others, 1998).

Recovery efficiencies during the Phase II investigation (49 to 81 percent) are approximately equal to or higher than those measured during the pilot study (38 to 61 percent). Enhancement of aquifer permeability may be suggested by the increase in recovery efficiency for the second 1-month storage test ( 81 percent). Although the recovery efficiency did not increase during the final two tests ( 55 and 49 percent, respectively), it did not diminish greatly with increasing lengths of storage.

\section{CONTINUATION OF PHASE II ASR TESTING}

Upon completion of ASR cycles at the downtown site, Phase II investigation results will be used to determine whether SL/BM aquifer properties are enhanced or degraded during long-term storage of treated drinking water. Water-quality characteristics measured during storage periods of increasing duration will allow quantification of reaction rates between water and aquifer material. The USGS geochemical model code PHREEQC (pH-redox-equilibrium; Parkhurst, 1995) will be used to quantify the extent and rate of dominant geochemical controls on water quality, including carbonate and silicate mineral dissolution, and sulfate reduction.

\section{REFERENCES CITED}

Campbell, B.G., Conlon, K.J., Mirecki, J.E., and Petkewich, M.D., 1997, Evaluation of aquifer storage recovery in the Santee Limestone/Black Mingo aquifer near Charleston, South Carolina, 1993-95: U.S. Geological Survey Water-Resources Investigations Report 96-4283, 89 p.

Mirecki, J.E., Campbell, B.G., Conlon, K.J., and Petkewich, M.D., 1998, Solute changes during aquifer storage recovery in a limestone/clastic aquifer: Ground Water, v. 36(6), p. 394-403.

Park, A.D., 1985, The ground-water resources of Charleston, Berkeley, and Dorchester Counties, South Carolina: Water Resources Commission Report Number 139, 145 p.

Parkhurst, D.L., 1995, User's guide to PHREEQC - A computer program for speciation, reaction-path, advectivetransport, and inverse geochemical calculations: U.S. Geological Survey Water-Resources Investigations Report 95-4227, $143 \mathrm{p}$.

Petkewich, M.D., Mirecki, J.E., Conlon, K.J., and Campbell, B.G., 2001, Aquifer storage recovery in the Santee Limestone/Black Mingo aquifer, Charleston, South Carolina, 1993-2000, in Proceedings of the 2001 Georgia Water Resources Conference, March 26-27, 2001: Athens, Ga., University of Georgia, p. 631-634.

U.S. Environmental Protection Agency, 1988, Secondary maximum contaminant levels (section 143.3 of part 143, national secondary drinking water regulations): U.S. Code of Federal Regulations, Title 40, Parts 100 to 149 , p. 608. 


\title{
Review and Hydrogeology of Aquifer Storage and Recovery Sites in Southern Florida
}

\author{
By Ronald S. Reese (rsreese@usgs.gov) \\ U.S. Geological Survey, 9100 NW $36^{\text {th }}$ Street, Suite 107, Miami, Florida 33178
}

\begin{abstract}
Aquifer storage and recovery in southern Florida has been proposed on an unprecedented scale as part of the Comprehensive Everglades Restoration Plan. Aquifer storage and recovery wells were constructed or are under construction at 27 sites in southern Florida, mostly by local municipalities or counties located in coastal areas. The Upper Floridan aquifer, the principal storage zone of interest to the restoration plan, is the aquifer being used at 22 of the sites. It is brackish to saline in southern Florida, which can greatly affect the recovery of the freshwater recharged and stored.
\end{abstract}

Well data were inventoried and compiled for all wells at most of the 27 sites. Construction and testing data were compiled into four main categories: (1) well identification, location, and construction data; (2) hydraulic test data; (3) ambient formation water-quality data; and (4) cycle testing data. Each cycle during testing or operation includes periods of recharge of freshwater, storage, and recovery that each last days or months. Cycle testing data include calculations of recovery efficiency, which is the percentage of the total amount of potable water recharged for each cycle that is recovered.

Calculated cycle test data includes potable water recovery efficiencies for 16 of the 27 sites. However, the number of cycles at most sites was limited; except for two sites, the highest number of cycles was five. Only 9 of the sites had a recovery efficiency above 10 percent for the first cycle, and 10 sites achieved a recovery efficiency above 30 percent during at least 1 cycle. The highest recovery efficiency achieved per cycle was 84 percent for cycle 16 at the Boynton Beach site.

Factors that could affect recovery of freshwater varied widely between sites. The thickness of the open storage zone at all sites ranged from 45 to 452 feet. For sites with the storage zone in the Upper Floridan aquifer, transmissivity based on tests of the storage zones ranged from 800 to 108,000 feet squared per day, leakance values indicated that confinement is not good in some areas, and the chloride concentration of ambient water ranged from 500 to 11,000 milligrams per liter.

Based on review of four case studies and data from other sites, several hydrogeologic and design factors appear to be most important to the performance of aquifer storage and recovery in the Floridan aquifer system. Performance is maximized when the storage zone is thin and located at the top of the Upper Floridan aquifer, and transmissivity and salinity of the storage zone are moderate (less than 30,000 feet squared per day and 3,000 milligrams per liter of chloride concentration, respectively). The structural setting at a site could also be important because of the potential for updip migration of a recharged freshwater bubble due to density contrast or loss of overlying confinement due to deformation. 


\title{
Technical Considerations for a Large Network of ASR wells in the Comprehensive Everglades Restoration Program
}

\author{
By Robert A. Renken ${ }^{1}$ (rarenken@usgs.gov), Michael W. Fies ${ }^{2}$, and Shawn B. Komlos ${ }^{3}$ \\ ${ }^{1}$ U.S. Geological Survey, 9100 NW 36 ${ }^{\text {th }}$ Street, Suite 107, Miami, Florida 33178 \\ ${ }^{2}$ U.S. Army Corps of Engineers, Jacksonville, FL \\ ${ }^{3}$ U.S. Environmental Protection Agency-U.S. Fish and Wildlife Service Liaison, West Palm Beach, FL
}

\begin{abstract}
The feasibility of constructing and implementing a network of large-capacity aquifer storage and recovery (ASR) wells is being evaluated as part of the U.S. Army Corps of Engineers (USACE) and South Florida Water Management District's (SFWMD) \$7.8 billion Comprehensive Everglades Restoration Plan (CERP). CERP represents the world's largest ecosystem restoration project attempted to date. ASR is an integral part of proposed storage features, and is the subject of pilot testing and a regional feasibility study to determine its ability to reduce water-supply competition during periods of drought. Successful implementation of the \$2 billion CERP ASR program depends heavily on a multidisciplinary approach to technical investigations. The proposed ASR project will involve injecting up to 1.6 billion gallons per day of treated surface water into the slightly saline Upper Floridan aquifer during southern Florida's summer wet season. During dry, winter seasons, stored water will be recovered for delivery to sustain the aquatic and semiaquatic Florida ecosystems while still helping to offset the growing urban and agricultural water-resource demands on regional water resources. Regional ASR also will be used to maintain stage levels in Lake Okeechobee and to minimize large surface-water flows to estuaries during periods of high rainfall. About 330 dual-purpose wells, with depths ranging from 600 to more than 1,000 feet, will be required for full successful implementation.
\end{abstract}

An ASR Issue Team, formed in September 1998 under the auspices of the South Florida Ecosystem Restoration Task Force, identified several critical uncertainties associated with implementing ASR on the scale proposed by CERP. Technical concerns were raised about the proposed use of ASR that relates to its unprecedented scale. Regional issues include the need to supplement relatively scarce subsurface information in areas where ASR wells will be located, and the effect on other Upper Floridan aquifer users by the incremental hydraulic head changes from the regional ASR well network. Water-quality issues include the need to characterize suitability of surface source waters for recharge to minimize extensive pretreatment, potential environmentally deleterious waterquality changes during storage in the aquifer, and concerns that recovered water quality could pose environmental or health concerns. The length of time that the surface source water remains in storage, and whether it could affect the water quality and result in lower recovery rates is also unknown. Local performance issues include the need to determine whether the proposed ASR injection volumes will result in pressures sufficient to fracture rock, and thereby alter the hydraulic properties of storage zones, as well as overlying and underlying confining units. Additionally, there is a lack of information concerning the relations among ASR storage zone properties, recharge volumes, and whether operational efficiency can be achieved to meet projected levels. Biochemical and ecotoxicological uncertainties add further complexity to evaluating overall ASR program feasibility. Biochemical and ecotoxicological concerns include the possibility of radionuclide release, increase in methylmercury bioaccumulation in the recovered water, and uncertainties associated with the survival, attenuation, and transport of pathogens during storage or recovery of partially untreated surface water. 


\title{
Effects of Artificial Recharge on Water Quality in the Equus Beds Aquifer, South-Central Kansas
}

\author{
By Andrew C. Ziegler (aziegler@usgs.gov) and Heather C. Ross (hross@usgs.gov) \\ U.S. Geological Survey, 4821 Quail Crest Place, Lawrence, Kansas 66049
}

\begin{abstract}
Water for 400,000 Wichita area residents comes from Cheney Reservoir (a large Federal impoundment) and a well field in the Equus Beds aquifer in south-central Kansas. These sources are not expected to meet the projected water needs for Wichita into the 21 st century. One alternative being investigated to help meet future water-supply demands for the city is artificial recharge of the aquifer in the well field area using high flows from the Little Arkansas River. This process may have an added benefit of preventing degradation of the aquifer from existing chloride plumes migrating toward the well field from a nearby oil field and from the Arkansas River.
\end{abstract}

From 1995 to 2000, more than 4,000 samples were collected from the Little Arkansas River, wells in the area, and monitoring wells at test sites in the well field area before and after an artificial recharge demonstration project began. Water samples were analyzed for more than 400 chemicals and bacteria. In samples collected before recharge, current (2001) U.S. Environmental Protection Agency (USEPA) drinking-water standards were exceeded for chloride, atrazine, and total coliform bacteria in surface-water samples and for arsenic in recharge water and one monitoring well at one of the test sites (Halstead).

Since artificial recharge began in 1997, there have been minimal effects on the quality of the existing ground water after recharging more than 1 billion gallons of water (5 percent of Wichita's annual water needs). After artificial recharge began, median concentrations of more than 400 chemicals including chloride, atrazine, and total coliform bacteria were all substantially less than their respective drinking-water standards and similar to concentrations in the receiving ground water before recharge. However, arsenic concentrations in the one monitoring well at the test site near Halstead increased from 8 to 19 micrograms per liter and exceeded the new (2001) USEPA drinking-water standard of 10 micrograms per liter. Continued monitoring of recharge and ground water will help prevent degradation of the water-quality in the Equus Beds aquifer. Current monitoring and interpretative information are available on the Internet at http://ks.water.usgs.gov/Kansas/equus/ . 